\title{
Permanent Closure of the TAN-664 Underground Storage Tank
}

December 2011

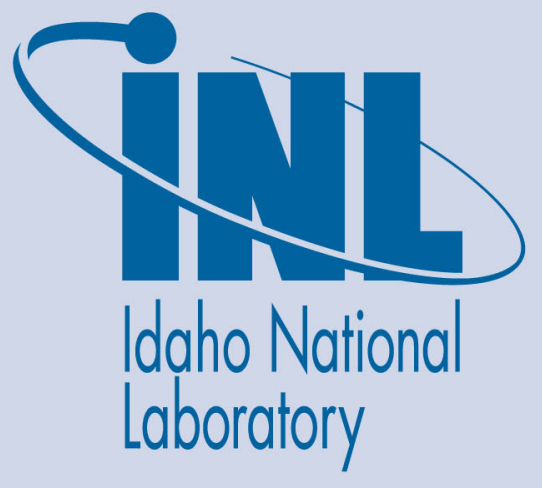

The INL is a U.S. Department of Energy National Laboratory operated by Battelle Energy Alliance 


\section{DISCLAIMER}

This information was prepared as an account of work sponsored by an agency of the U.S. Government. Neither the U.S. Government nor any agency thereof, nor any of their employees, makes any warranty, expressed or implied, or assumes any legal liability or responsibility for the accuracy, completeness, or usefulness, of any information, apparatus, product, or process disclosed, or represents that its use would not infringe privately owned rights. References herein to any specific commercial product, process, or service by trade name, trade mark, manufacturer, or otherwise, does not necessarily constitute or imply its endorsement, recommendation, or favoring by the U.S. Government or any agency thereof. The views and opinions of authors expressed herein do not necessarily state or reflect those of the U.S. Government or any agency thereof. 


\section{Permanent Closure of the TAN-664 Underground Storage Tank}

December 2011

Idaho National Laboratory Idaho Falls, Idaho 83415

http://www.inl.gov

Prepared for the

U.S. Department of Energy

Office of Nuclear Energy

Under DOE Idaho Operations Office

Contract DE-AC07-05ID14517 



\section{CONTENTS}

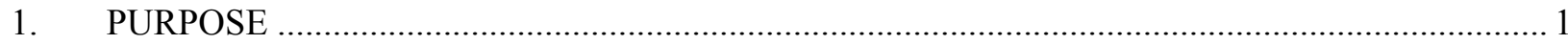

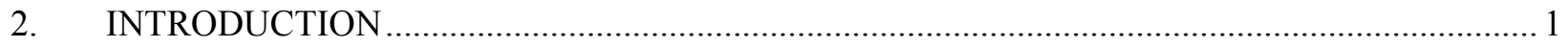

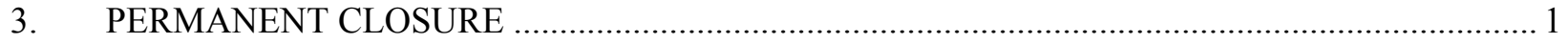

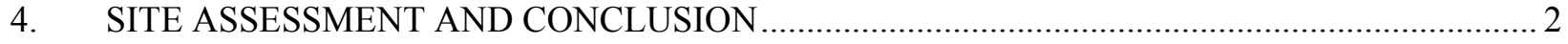

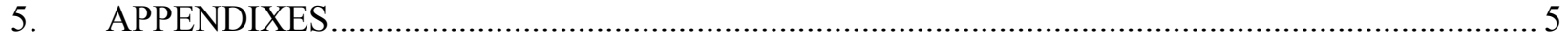

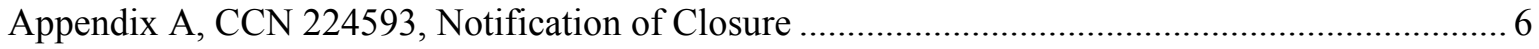

Appendix B, CCN 224670, Sampling and Analysis Plan ......................................................... 14

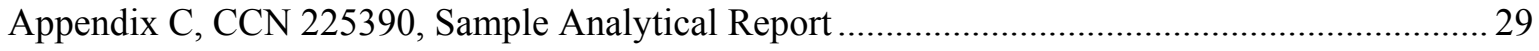

\section{FIGURES}

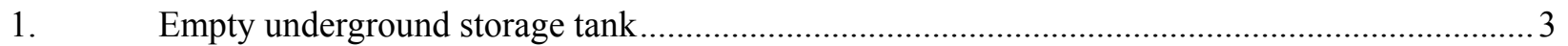

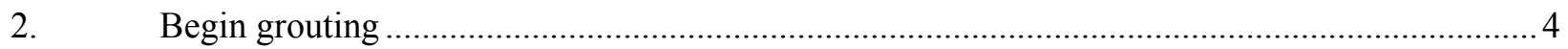

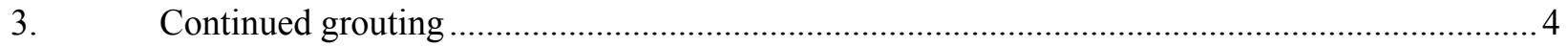

4. TAN-664 gasoline underground storage tank filled with grout............................................. 5

\section{TABLES}

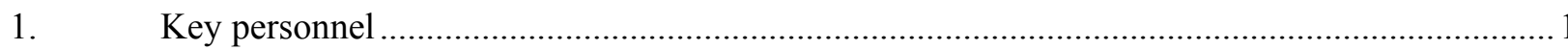




\section{Permanent Closure of the TAN-664 Underground Storage Tank}

\section{PURPOSE}

This closure package documents the site assessment and permanent closure of the TAN-664 gasoline underground storage tank in accordance with the regulatory requirements established in 40 CFR 280.71, "Technical Standards and Corrective Action Requirements for Owners and Operators of Underground Storage Tanks: Out-of-Service UST Systems and Closure."

\section{INTRODUCTION}

The TAN-664 gasoline underground storage tank is a 15,000-gallon, double-walled, fiberglassreinforced plastic tank, with pressurized double-walled fiberglass piping, and is located at the Idaho National Laboratory (INL) Test Area North (TAN) facility. The tank is owned by the Department of Energy and operated by Battelle Energy Alliance (BEA). The tank provided gasoline for motor vehicle use via the TAN-664 fuel dispenser. This tank is identified under Site ID 3560, \#6-120044-17 in the Idaho Department of Environmental Quality (DEQ) underground storage tank database and is identified as tank 98TAN00491 in the INL tank database. The tank leak detection system was a Veeder-Root TLS-350 tank monitoring, automatic tank gauging system with continuous statistical leak detection. Mechanical line leak detector and line tightness tests were performed annually on the pressurized piping.

In 2010, it was determined that the TAN-664 fueling station would no longer be needed due to closure of many of the TAN facilities. The fuel station building (TAN-664) and the associated underground storage tank were included in the scope of work for an upcoming demolition project. Key personnel that were involved in this closure/demolition activity are listed in Table 1.

Table 1. Key personnel.

\begin{tabular}{lll}
\hline \multicolumn{1}{c}{ Title/Organization } & \multicolumn{1}{c}{ Name } & \multicolumn{1}{c}{ Responsibilities } \\
\hline Project Manager & Colvin Jergins* & Project execution and completion \\
Facility Manager & Don Blatter & Manage/approve facility activities \\
Environmental Compliance & Brad Griffith & Coordinate UST closure activity \\
Project Supervisor & Delbert Loosli & Project implementation \\
\hline
\end{tabular}

*The previous project manager (Roderick Nelson) retired during this closure activity and was replaced by Colvin Jergins.

In preparation for demolition and permanent tank closure, the remaining fuel in the line and tank was pumped out on June 8, 2011, and the tank was placed in temporary closure in accordance with 40 CFR 280.70 .

\section{PERMANENT CLOSURE}

In accordance with 40 CFR 280.71(a), a 30-day closure notification was mailed on June 29, 2011, (Appendix A, CCN 224593) notifying Idaho DEQ of BEA's intent to permanently close (grout) the TAN-664 gasoline underground storage tank. A sampling and analysis plan was developed for sampling the soils under the underground storage tank system. The Idaho DEQ Regional Office in Idaho Falls (i.e., S. Short and S. Heaton) requested a copy of the sampling and analysis plan in preparation for the closure. The sampling and analysis plan was sent to both the Idaho DEQ State and Regional Offices on July 8, 2011 (Appendix B, CCN 224670). Idaho DEQ also requested they be notified of the sampling date so they could observe the sampling activities. 
On July 18, 2011, INL's Environmental Monitoring personnel collected soil samples under both the underground storage tank and supply line in accordance with the sampling and analysis plan. Idaho DEQ personnel, Stacy Short and Steve Heaton, were present for the sampling activity. A trailer-mounted power probe was used to collect the samples. BEA's industrial hygienist used a MiniRae 2000 Photoionization Detector to scan the probe holes and soil samples; no hydrocarbons were detected. Soil samples were sent to Test America-St. Louis for analysis. Laboratory analysis was requested for benzene, toluene, xylenes, MTBE, and naphthalene because these are the chemicals of interest in Table 1 of IDAPA 58.01.24.800.01, "Chemicals of Interest for Various Petroleum Products," for unleaded gasoline.

Test America-St. Louis sent the final analytical report on July 28, 2011, to INL's Environmental Monitoring personnel. This analytical report was sent to Stacy Short of Idaho DEQ on September 22, 2011(Appendix C, CCN 225390). Sample results showed non-detection for the chemicals of interest for all samples that were taken. Concentrations were under the residential use screening levels identified in Table 2 of IDAPA 58.01.24.800.02, "Residential Use Screening Levels."

After the analytical results were received, facility craft personnel accessed the inside of the tank through the west manhole and removed all remaining liquids (i.e., a small amount at the slightly sloped end) with an air-peristaltic pump and mopped the tank out with absorbent pads. Waste that was generated during this process was disposed of through INL's Waste Generator Services personnel. All liquids and accumulated sludges were removed, meeting the requirement in 40 CFR 280.71(b), "Permanent Closure and Changes-In-Service" (Figure 1).

On September 21, 2011, Stacy Short of the Idaho DEQ Regional Office in Idaho Falls was notified (CCN 225378) of the date BEA intended to fill the TAN-664 underground storage tank with grout, closing it in place. This notification was given more than 48 hours prior to grouting the tank. Ms. Short indicated she and Steve Heaton would like to be present during the grouting activity and would like to complete compliance inspections for the Advanced Test Reactor Complex, Naval Reactors Facility, and TAN. On September 26, 2011, Ms. Short scheduled compliance inspections for the Advanced Test Reactor Complex, Naval Reactors Facility, and the TAN underground storage tanks on the same day as the tank grouting (September 27, 2011).

On September 27, 2011, Stacy Short and Steve Heaton finished the compliance inspections with the TAN diesel underground storage tank and were given the opportunity to witness the scheduled grouting activity. However, they elected to not observe the tank grouting due to schedule restraints. Cement trucks began arriving at approximately 1:00 p.m. and continued on throughout the afternoon. Approximately 72 y3 of grout were used to completely fill the underground storage tank (Figures 2 through 4). The grouted underground storage tank was later covered with soil and the site was leveled to the surrounding land surface and placed in a safe configuration.

\section{SITE ASSESSMENT AND CONCLUSION}

This site assessment was performed in accordance with IDAPA 58.01.24.200, "Risk Evaluation Process." A screening evaluation was performed according to the previously submitted sampling and analysis plan of the TAN-664 fuel tank (Appendix B). This included collection of media-specific (soil) samples and analysis for the chemicals of interest (benzene, toluene, xylenes, MTBE, and naphthalene) for unleaded gasoline (IDAPA 58.01.24.200. $\mathrm{a}$ and b. and IDAPA 58.01.24.800.01, Table 1.)

Sample results (Appendix C) were received on July 28, 2011, and were compared to the maximum media-specific (soil) petroleum contaminant concentrations identified in IDAPA 58.01.24.800.02, Table 2. Sample results showed non-detection for the chemicals of interest and were below the levels identified in Table 2. 
According to IDAPA 58.01.24.200.c., if the concentrations of the chemicals of interest are below the Table 2 screening levels, the owner/operator can petition for site closure. This site assessment meets the requirements of IDAPA 58.01.24.200 and approval of the final closure of the TAN-664 gasoline underground storage tank is requested. A final updated copy of the 30-day closure notification has been included.

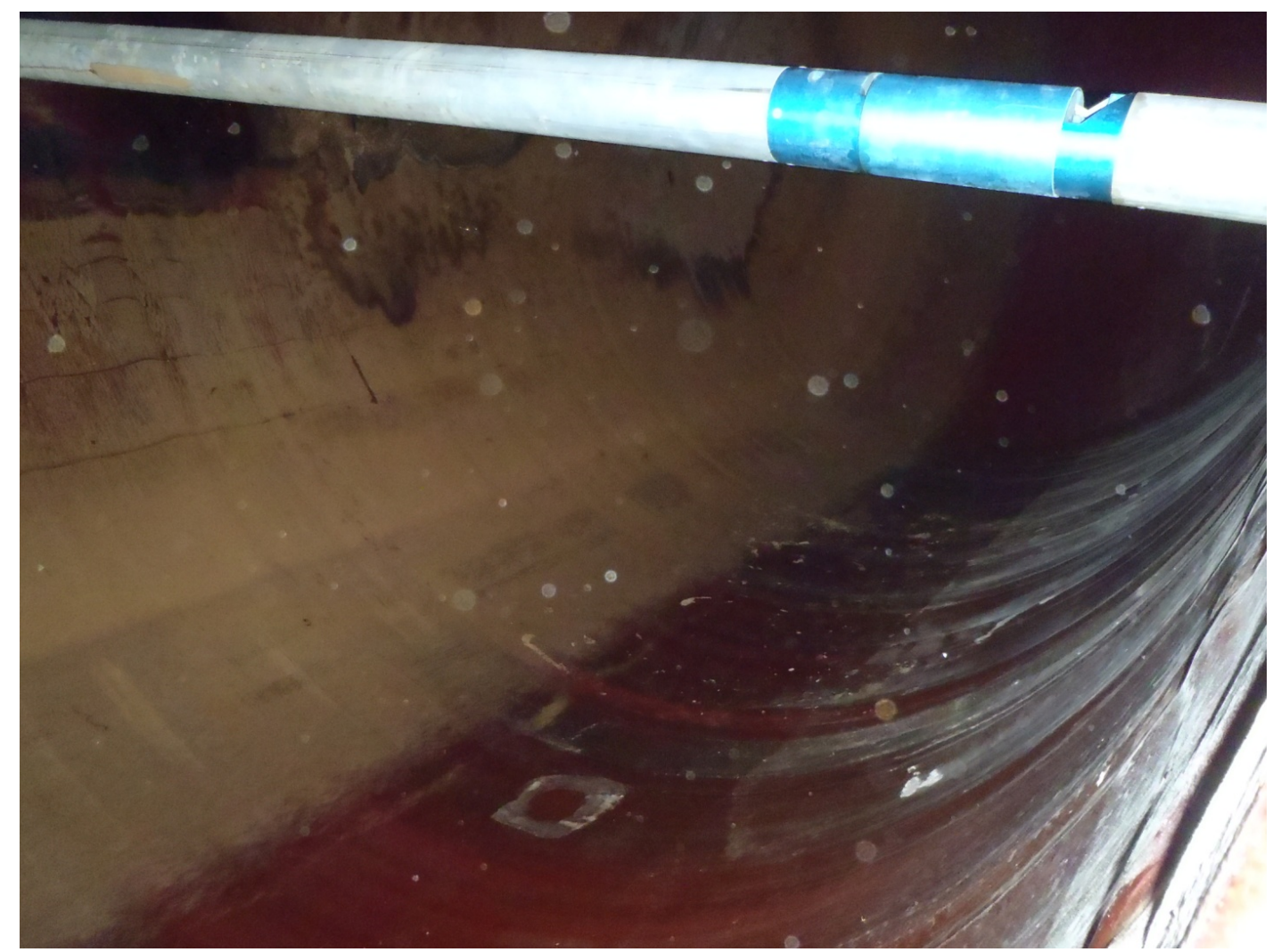

Figure 1. Empty underground storage tank. 


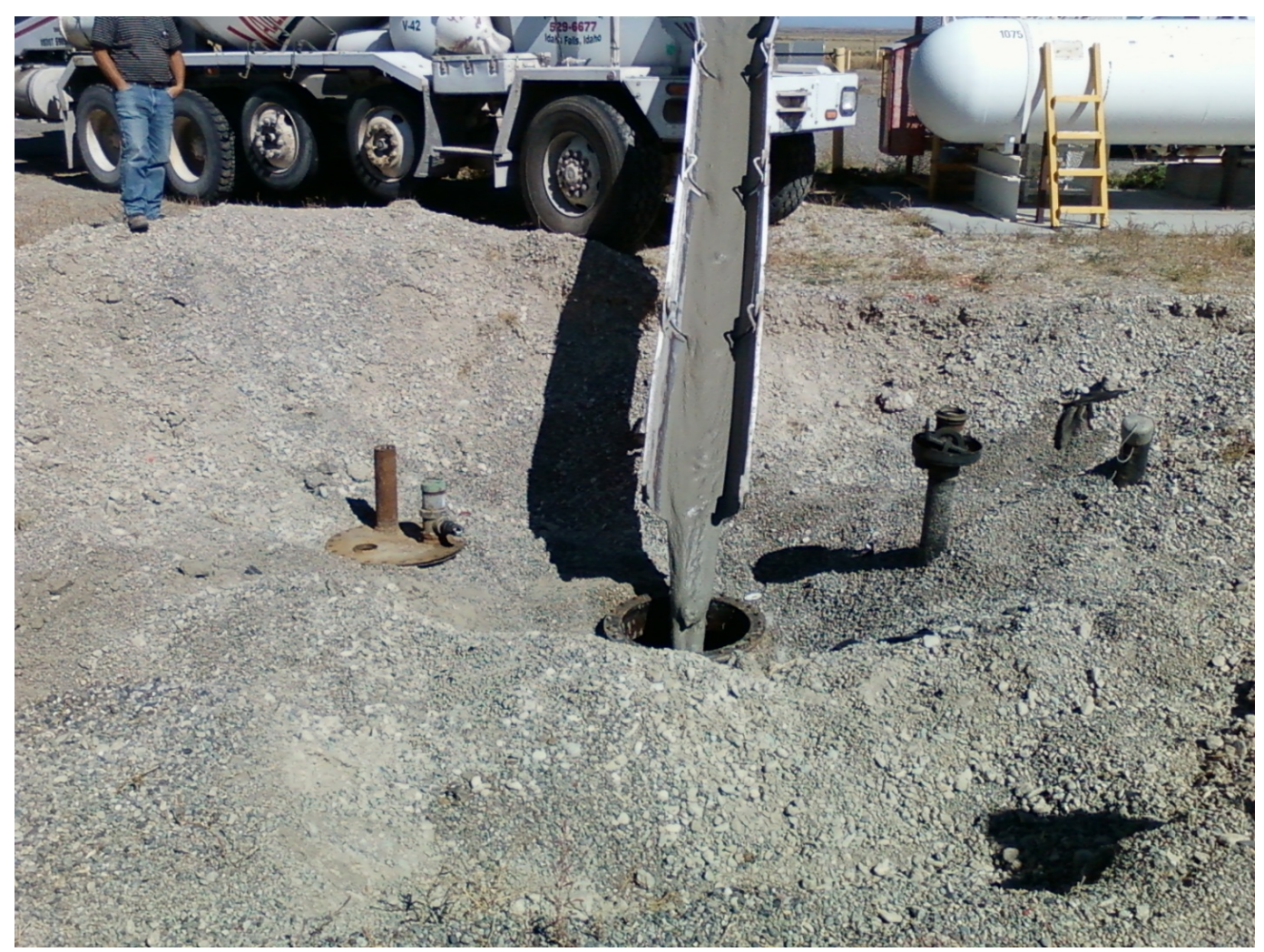

Figure 2. Begin grouting.

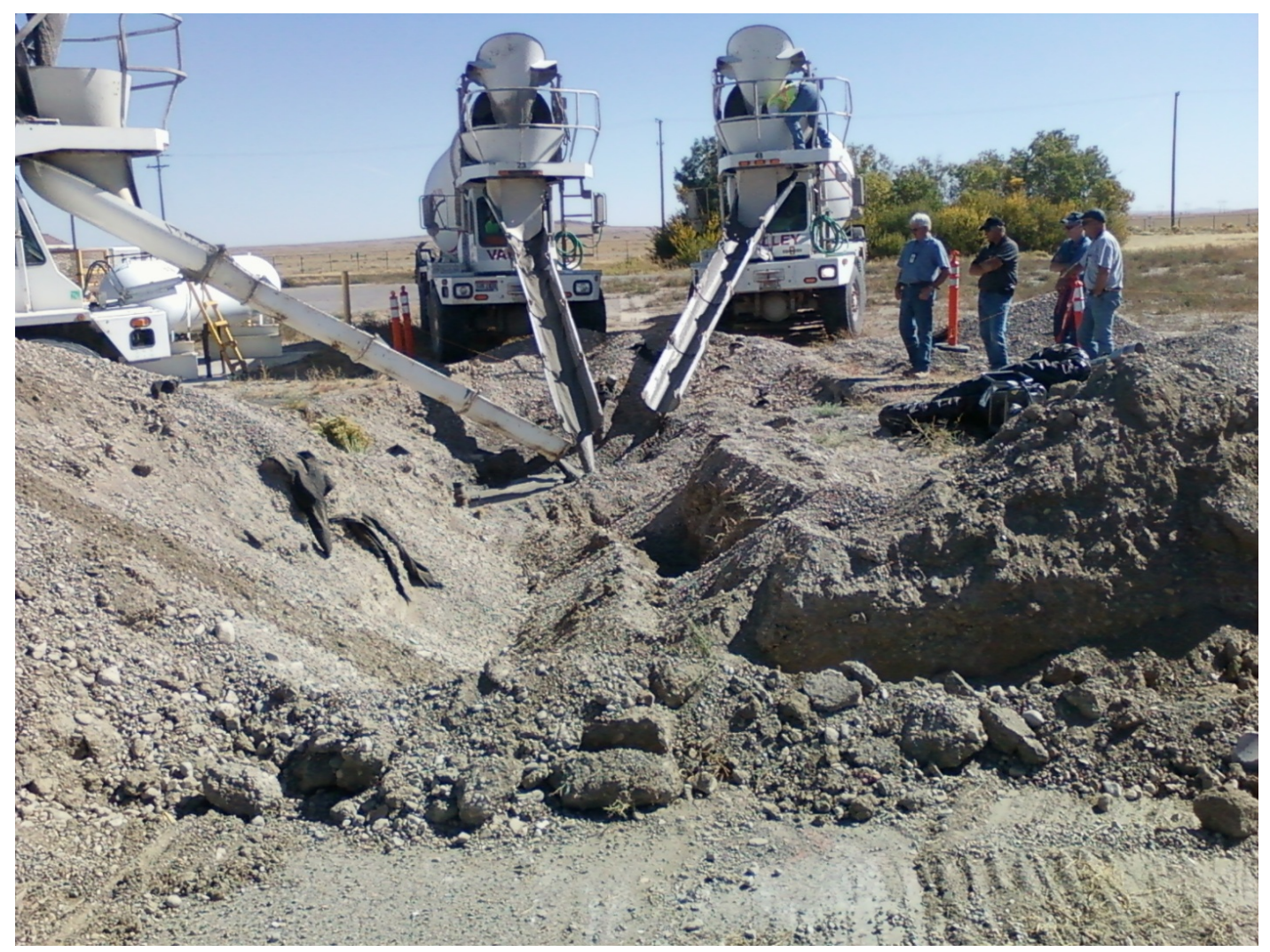

Figure 3. Continued grouting. 


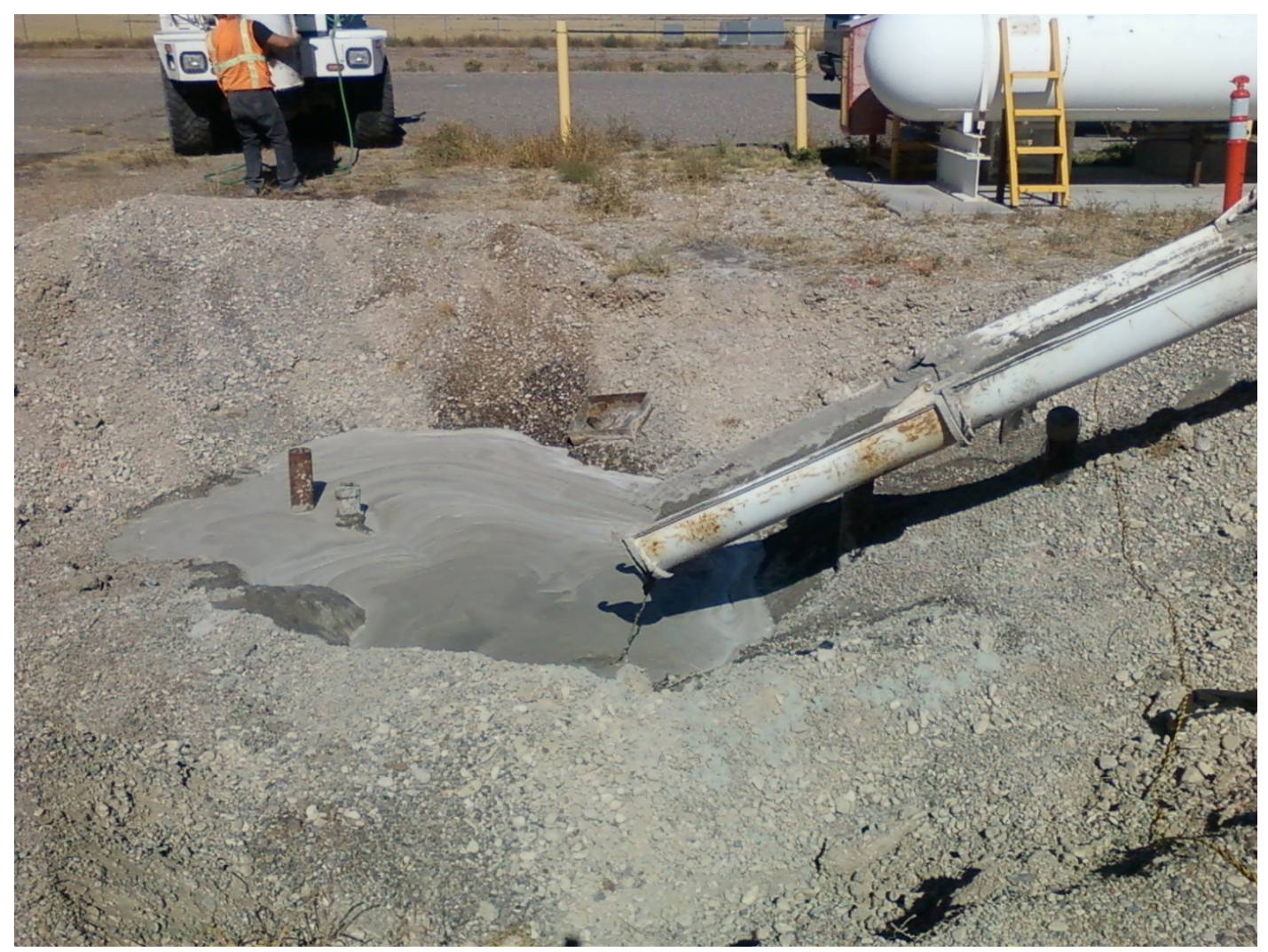

Figure 4. TAN-664 gasoline underground storage tank filled with grout.

\section{APPENDIXES}

Appendix A, CCN 224593, Notification of Closure

Appendix B, CCN 224670, Sampling and Analysis Plan

Appendix C, CCN 225390, Sample Analytical Report 


\section{Appendix A \\ CCN 224593, Notification of Closure}

June 29, 2011

CCN 224593

Kristi Lowder

UST Coordinator

Idaho Department of Environmental Quality

1410 North Hilton

Boise, ID 83706

SUBJECT: Notification for Underground Storage Tank Closure at Idaho National Laboratory, Test Area North

Dear Ms. Lowder:

This letter provides 30-day notification of intent to close an underground storage tank located at the Idaho National Laboratory, Test Area North (Site $3560-6-120044^{*} 17$ ). This notice is submitted for Battelle Energy Alliance, LLC (BEA) as the operating contractor for this project.

The enclosed notification provides the necessary information and notification required by Title $40 \mathrm{CFR}$ 280 , Subpart G. Please note that a follow up notification will be submitted with the required site assessment and the information required in section XI. BEA has communicated with the Idaho DEQ Regional Office in Idaho Falls (S. Short and S. Heaton) regarding this closure and will provide them with a copy of this notification, a sample plan (to be submitted by July 8,2011) and a 48-hour notification prior to closure.

If you have any questions, please contact Brad Griffith at (208) 533-4530.

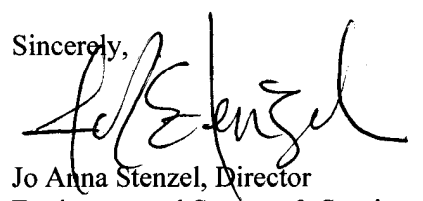

Environmental Support \& Services

BKG:AT

Enclosure

cc: J. Alvarez, INL, MS 3695

P. K. Bowers, DOE-ID, MS 1226

P. J. Breidenbach, INL, MS 6146

R. R. Chase, INL, MS 3695

S. D. Dossett, INL, MS 3405

R. A. Gallegos, DOE-ID, MS 1216

J. J. Grossenbacher, INL, MS 3695
S. Heaton, DEQ, Idaho Falls

S. M. Olson, DOE-ID, MS 1240

T. L. Perkins, DOE-ID, MS 1216

S. Short, DEQ, Idaho Falls

D. M. Storms, INL, MS 3898

J. R. Sturm, DOE-ID, MS 1216

P.O. Box 1625 - 2525 North Fremont Ave. • Idaho Falls, Idaho 83415 • 208-526-0111 • www.inl.gov 
Ms. Kristi Lowder

June 29, 2011

CCN 224593

Page 2

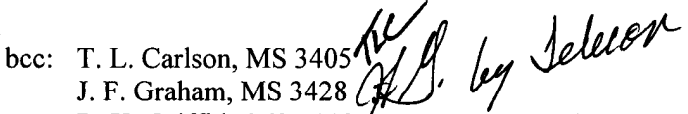

B. K. Griffith, MS 7113

S. D. Lee, MS 3405

T. A. Miller, MS 3428

R. V. Nelson, MS 3406

N. E. Stanley, MS 4131

D. W. Wagoner, MS 3405

INL Correspondence Control, MS 3640, email: BEACC@inl.gov

Environmental Correspondence, MS 3405, email: ENVAFF@inl.gov

J. A. Stenzel Letter Log (JAS-53-11)

Uniform File Code: 5163

Disposition Authority: ENV1-d-13

Retention Schedule: Cut off annually. Destroy after 75 years

NOTE: Original disposition authority, retention schedule, and Uniform Filing Code applied by the sender may not be appropriate for all recipients. Make adjustments as needed. 


\begin{tabular}{|l|l|}
\hline NOTIFICATION FOR UNDERGROUND STORAGE TANK SYSTEMS & Facility ID \\
\hline Idaho Department of Environmental Quality, 1410 N Hilton, Boise ID 83706 & $\underline{3560-6-120044^{*} 17}$ \\
\hline
\end{tabular}

\section{TYPE OF NOTIFICATION}

\Notice $\square$ New Facility (site diagram \& install testing docs required) $\square$ Updates $\square$ Closure
INSTRUCTIONS - See additional instructions on page 7

Please type or use ink. This form must be completed for each location containing underground storage tanks. If more than five (5) tanks are owned at this location, photocopy the following sheets, and staple continuation sheets to the form (pages 3,4 , $5, \& 6)$

\section{GENERAL INFORMATION}

Notification is required by law for all underground tanks that have been used to store regulated substances since January 1,1974 , that are in the ground as of May 8, 1986, or that are brought into use after May 8, 1986. The information requested is required by Section 9002 of the Resource information requested is required by Section 9002 of the
Conservation and Recovery Act, (RCRA), as amended.

The primary purpose of this notification program is to locate and evaluate underground tanks that will store, do store, or have stored petroleum or hazardous substances. It is expected that the information you provide will be based on reasonably available records, or in the absence of such records, your knowledge, belief, or recollection.

Who must notify? Unless exempted, owners of underground tank systems

that store or will store regulated substances must notify DEQ.

1. Owner means -

a) in the case of an underground storage tank in use on November 8,1984 , or brought into use after that date, any person who owns an underground storage tank used for the storage, use, or dispensing of regulated substances, and b) in the case of any underground storage tank in use before November 8 , 1984 , but no longer in use on that date, any person who owned such tank immediately before the discontinuation of its use

c) in the case of a new installation on or after April 2, 2008, any person who will install an underground storage tank system

d) in the case of an underground storage tank closure, any person who will remove or close in place such tank

e) any facility that has undergone any changes to facility information or tank system status (only amended tank information needs to be included)

What tanks are included? Underground storage tank is defined as any one or combination of tanks that (1) is used to contain an accumulation of "regulated substances," and (2) whose volume (including connected underground piping) is $10 \%$ or more beneath the ground. Some examples are underground tanks storing gasoline, used oil, diesel fuel, industrial solvents, pesticides, herbicides, or fumigants.

What tanks are excluded? Tanks with a capacity of 110 gallons or less are not subject to notification. Other tanks excluded from notification are

1. farm or residential tanks of 1,100 gallons or less capacity used for storing motor fuel for noncommercial purposes:

2. tanks used for storing heating oil for consumptive use on the premises where stored;

3. septic tanks;

4. pipeline facilities (including gathering lines) regulated under the Natural Gas Pipeline Safety Act of 1968, or the Hazardous Liquid Pipeline Safety Act of

1979 , or which is an intrastate pipeline facility regulated under State laws;

5. surface impoundments, pits, ponds, or lagoons:

6 . storm water or waste water collection systems;

7. flow-through process tanks:

8. liquid traps or associated gathering lines directly related to oil or gas production and gathering operations:

9. storage tanks situated in an underground area (such as a basement, cellar, mine working drift, shaft, or tunnel) if the storage tank is situated upon or above the surface of the floor. What substances are covered? The notification requirements apply to underground storage tanks that contain regulated substances. This includes any substance defined as hazardous in section 101 (14) of the Comprehensive Environmental Response, Compensation and Liability Act of 1980 (CERCLA), with the exception of those substances regulated as hazardous waste under Subtitle $C$ of RCRA. It also includes petroleum, e.g., crude oil or any fraction thereof which is liquid at standard conditions of temperature and pressure $(60$ degrees Fahrenheit and 14.7 pounds per square inch absolute). Where to notify? Send completed forms to:

UST Coordinator Idaho Department of Environmental Quality $1410 \mathrm{~N}$. Hilton

Boise, ID 83706 Telephone: (208) 373-0502

When to notify? Owners of underground storage tank systems that are still in the ground must notify immediately. Owners who bring underground storage tanks into use after May 8, 1986, must notify within 30 days of bringing the tanks into use. Owners who will install an underground storage tank system must notify 30 days prior to the installation. Own installation. Owr single underground storage tank must notify 24 hours prior to the
replacement. Owners who will close an underground storage tank must notify 30 days prior to the closure. Owners who have closed an underground storage tank must notify and indicate the date of closure.

Penalties: Any owner who knowingly fails to notify or submits false information shall be subject to a civil penalty.

EPA estimates public reporting burden for this form to average 30 minutes per response including time for reviewing instructions, gathering and maintaining the data needed and completing and reviewing the form. Send comments regarding this burden estimate to Chief, Information Policy Brand PM-223, US Environmental Protection Agency, 401 M Street, Washington D.C. 20460, marked "Attention Desk Officer for EPA." This form amends the previous notification form as printed in 40 CFR Part 280, Appendix I.

\section{OWNERSHIP OF TANK(S)}

\section{LOCATION OF TANK(S)}

Name U.S. Department of Energy, Idaho Operations Office (DOE-ID)

Mailing Address 1955 Fremont Avenue

City Idaho Falls

State Idaho

ZIP Code 83415

County Bonneville

Phone Number (With Area Code) (208)526-2493

(If same as Section I, mark box here $\square$ ) Name Test Area North- Idaho National Laboratory Street Address (no PO Box)

City Scoville

State Idaho

County Butte 
Email sturmir@id.doe.gov

III. TYPE OF OWNER

\begin{tabular}{|l|cc} 
& III. TYPE OF OWNER \\
\hline Commercial & $\square$ Private & $\square$ State Government \\
& $\square$ Federal Government & $\square$ Local Government
\end{tabular}

\section{TYPE OF FACILITY}

Select the Appropriate Facility

Description

$\square$ Gas Station

Petroleum Distributor

$\square$ Air Taxi (Airline)

$\square$ Aircraft Owner

$\square$ Auto Dealership

Railroad

$\square$ Local Government
$\square$ State Government
$\square$ Federal - Non-Military
$\square$ Federal - Military
$\square$ Commercial
$\square$ Industrial
$\square$ Hospital

\begin{tabular}{l}
$\square$ Contractor \\
$\square$ Trucking/Transport \\
$\square$ Utilities \\
$\square$ Farm \\
$\square$ Residential \\
\hline$\square$ Marina \\
\hline$\square$ (Other)
\end{tabular}

V. CONTACT PERSON IN CHARGE OF TANKS

Name Roderick V. Nelson

Title Project Manager

Address 1955 Fremont Avenue, Idaho Falls, Idaho

83415

City Scoville

State ID

Zip Code 83415

Phone (208) 526-9863

Email roderick.nelson@inl.gov

\section{CERTIFICATION (Read and sign after completing all sections)}

I certify under penalty of law that I have personally examined and am familiar with the information submitted in this and all attached documents, and that based on my inquiry of those individuals immediately responsible for obtaining the information, I believe that the submitted information is true, accurate, and complete.

Name and official title of owner or owner's authorized representative (Print)

Name Jo Anna Stenzel

Title Director, Environmental Support and Services

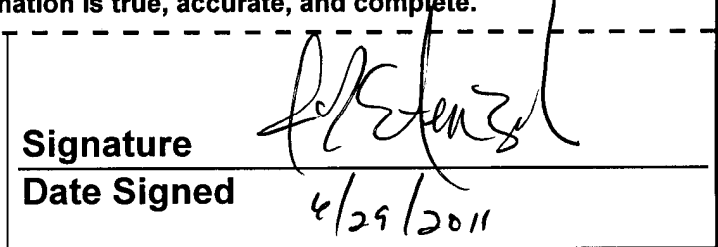

\section{FINANCIAL RESPONSIBILITY}

I have met the financial responsibility requirements in accordance with 40 CFR 280 Subpart $H$.

Check All That Apply

$\square$ State Insurance Fund (PSTF)

$\square$ Surety Bond

$\square$ Commercial Insurance

$\square$ Letter of Credit

$\square$ Risk Retention Group

$\square$ Self Insurance

$\square$ Guarantee

$\square$ Trust Fund

囚other Method Allowed, Specify Federal Facility 


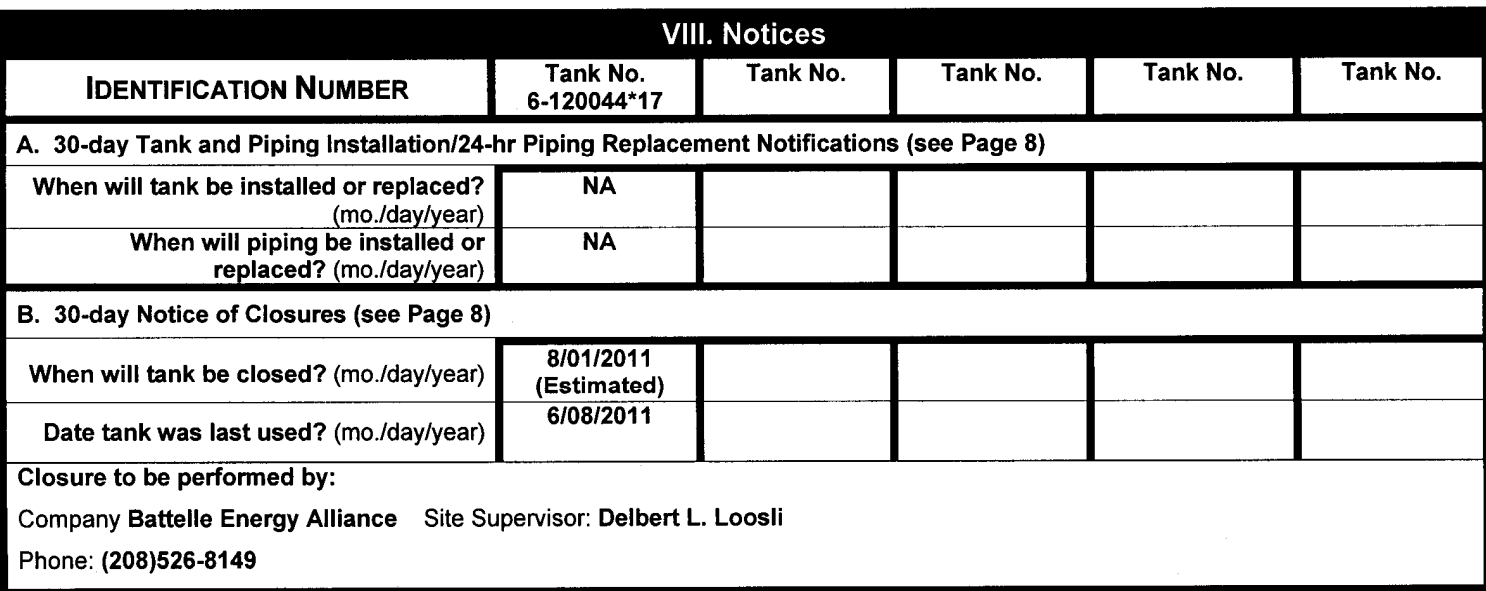

\section{Ground Water Protection Measures}

(Check the applicable box)

The underground storage tank system IS within 1000' of a drinking water source or system. $\bigotimes$

The underground storage tank system IS NOT within 1000' of a drinking water source or system.

If the owner and installer certify that the underground storage tank system is not within 1000' of an existing public water system or potable drinking water well, the owner or operator must provide and maintain documentation showing that a reasonable investigation of water systems and drinking water wells well, the owner or
was undertaken.

\section{DESCRIPTION OF UNDERGROUND STORAGE TANKS (Complete for each tank at this location)}

\begin{tabular}{|c|c|c|c|c|c|}
\hline IDENTIFICATION NUMBER & $\begin{array}{c}\text { Tank No. } \\
6-120044^{*} 17\end{array}$ & Tank No. & Tank No. & Tank No. & Tank No. \\
\hline Compartmentalized/Manifolded Tanks? & Select & Select & Select & Select & Select \\
\hline Emergency Generator Tank? & No & Select & Select & Select & Select \\
\hline \multicolumn{6}{|l|}{ A. Status of Tank } \\
\hline Currently In Use & No & Select & Select & Select & Select \\
\hline $\begin{array}{r}\text { Temporarily Out of Use } \\
\text { (Complete Section XI, Estimated Date Last Used) }\end{array}$ & $06 / 08 / 2011$ & & & & \\
\hline $\begin{array}{r}\text { Permanently Out of Use } \\
\text { (Complete Section XI, tanks removed or closed in place) }\end{array}$ & Select & Select & Select & Select & Select \\
\hline Date of Installation (mo./day/year) & $11 / 1991$ & & & & \\
\hline Total Capacity (gallons) & 15000 & & & & \\
\hline
\end{tabular}

B. Material of Tank Construction (Mark all that apply)

Fiberglass Reinforced Plastic

Cathodically Protected Steel (STIP-3) Cathodically Protected Steel (Impressed

$$
\text { Epoxy Coated Stee }
$$

Composite (Steel with Fiberglass)

\begin{tabular}{|c|c|c|c|c|}
\hline$\square$ & $\square$ & $\square$ & $\square$ \\
\hline$\square$ & $\square$ & $\square$ & $\square$ & $\square$ \\
\hline$\square$ & $\square$ & $\square$ & $\square$ & $\square$ \\
\hline$\square$ & $\square$ & $\square$ & $\square$ & $\square$ \\
\hline$\square$ & $\square$ & $\square$ & $\square$ & $\square$ \\
\hline
\end{tabular}

Page 3 


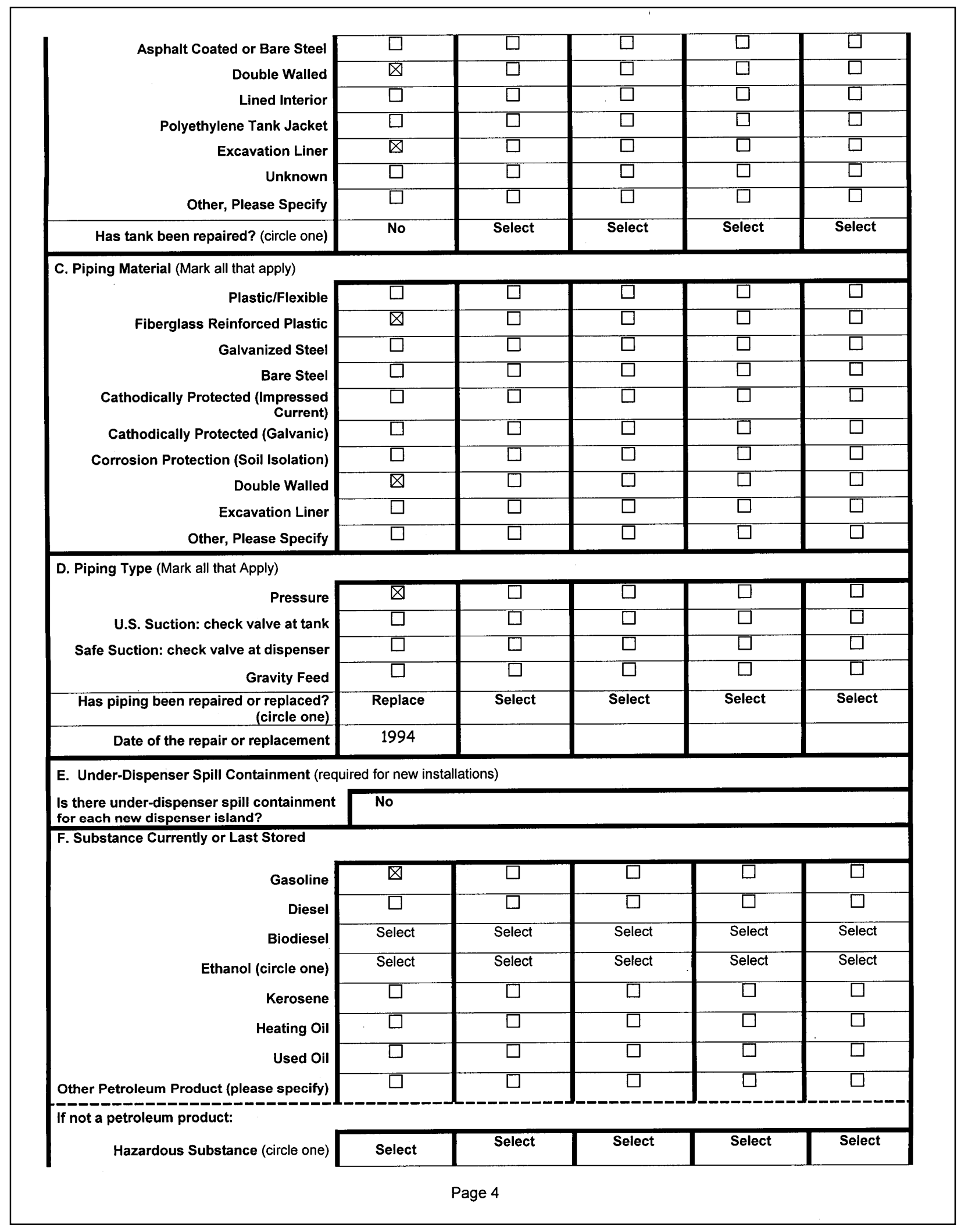




\begin{tabular}{|c|c|c|c|c|c|}
\hline $\begin{array}{r}\text { CERCLA name and/or, } \\
\text { CAS Number } \\
\text { (Chemical Abstract Service Registry \#) }\end{array}$ & & & & & \\
\hline If not listed above: & & & & & \\
\hline Mixture of Substances (please specify) & Select & Select & Select & Select & Select \\
\hline XI. T & NKS OUT OF U & OR CHANC & ERVICE & & \\
\hline TANK IDENTIFICATION NUMBER & $\begin{array}{c}\text { Tank No. } \\
6-120044^{*} 17 \\
\end{array}$ & Tank No. & Tank No. & Tank No. & Tank No. \\
\hline Closing of Tank & & & & & \\
\hline Tank was removed from ground & $\square$ & $\square$ & $\square$ & $\square$ & $\square$ \\
\hline Tanks was closed in ground & $\square$ & $\square$ & $\square$ & $\square$ & $\square$ \\
\hline $\begin{array}{r}\text { Estimated date last used } \\
\text { (mo./day/year) }\end{array}$ & $06 / 08 / 2011$ & & & & \\
\hline $\begin{array}{r}\text { Date tank closed } \\
(\text { mo./day/year })\end{array}$ & & & & & \\
\hline $\begin{array}{r}\text { Tank Filled with inert material } \\
\text { (indicate material) }\end{array}$ & $\begin{array}{c}\text { tank will be } \\
\text { filled with grout }\end{array}$ & & & & \\
\hline $\begin{array}{r}\text { Change in Service (no longer holds a } \\
\text { regulated substance) }\end{array}$ & $\square$ & $\square$ & $\square$ & $\square$ & $\square$ \\
\hline $\begin{array}{r}\text { Site Assessment Completed and } \\
\text { submitted to DEQ (circle one) }\end{array}$ & Select & Select & Select & Select & Select \\
\hline Evidence of a leak detected (circle one) & Select & Select & Select & Select & Select \\
\hline Release reported to DEQ & Select & Select & Select & Select & Select \\
\hline Date release reported to DEQ & & & & & \\
\hline
\end{tabular}

\begin{tabular}{|c|c|c|c|c|c|c|c|c|c|c|}
\hline \multicolumn{11}{|c|}{$\begin{array}{c}\text { XII. CERTIFICATION OF COMPLIANCE } \\
\text { (Complete for installation of all new tanks or for upgrading existing tanks at this location) }\end{array}$} \\
\hline \multicolumn{11}{|l|}{ A. Installation (Mark all that apply) } \\
\hline $\begin{array}{r}\text { Installer certified by tank and piping } \\
\text { manufacturers }\end{array}$ & \multicolumn{2}{|c|}{$\square$} & \multicolumn{2}{|c|}{$\square$} & \multicolumn{2}{|c|}{$\square$} & \multicolumn{2}{|c|}{$\square$} & \multicolumn{2}{|c|}{$\square$} \\
\hline Installer certified or licensed by a State & \multicolumn{2}{|c|}{$\square$} & \multicolumn{2}{|c|}{$\square$} & \multicolumn{2}{|c|}{$\square$} & \multicolumn{2}{|c|}{$\square$} & \multicolumn{2}{|c|}{$\square$} \\
\hline $\begin{array}{r}\text { Installation is inspected by a registered } \\
\text { engineer }\end{array}$ & \multicolumn{2}{|c|}{$\square$} & \multicolumn{2}{|c|}{$\square$} & \multicolumn{2}{|c|}{$\square$} & \multicolumn{2}{|c|}{$\square$} & \multicolumn{2}{|c|}{$\square$} \\
\hline Installation inspected by $D E Q$ & \multicolumn{2}{|c|}{$\square$} & \multicolumn{2}{|c|}{$\square$} & \multicolumn{2}{|c|}{$\square$} & \multicolumn{2}{|c|}{$\square$} & \multicolumn{2}{|c|}{$\square$} \\
\hline $\begin{array}{r}\text { Manufacturer's installation checklists } \\
\text { have been completed }\end{array}$ & \multicolumn{2}{|c|}{$\square$} & \multicolumn{2}{|c|}{$\square$} & \multicolumn{2}{|c|}{$\square$} & \multicolumn{2}{|c|}{$\square$} & \multicolumn{2}{|c|}{$\square$} \\
\hline B. Release Detection (Mark one) & Tank & Piping & Tank & Piping & Tank & Piping & Tank & Piping & Tank & Piping \\
\hline Automatic Tank Gauging & $\square$ & $\square$ & $\square$ & $\square$ & $\square$ & $\square$ & $\square$ & $\square$ & $\square$ & $\square$ \\
\hline $\begin{array}{r}\text { Interstitial Monitoring Double Walled } \\
\text { Tank/Piping }\end{array}$ & $\square$ & $\square$ & $\square$ & $\square$ & $\square$ & $\square$ & $\square$ & $\square$ & $\square$ & $\square$ \\
\hline $\begin{array}{l}\text { Inventory Control/Manual Tank Gauging } \\
\text { with Tank Tightness Testing }\end{array}$ & $\square$ & $\square$ & $\square$ & $\square$ & $\square$ & $\square$ & $\square$ & $\square$ & $\square$ & $\square$ \\
\hline SIR & $\square$ & $\square$ & $\square$ & $\square$ & $\square$ & $\square$ & $\square$ & $\square$ & $\square$ & $\square$ \\
\hline Manual Tank Gauging (1,000 gal or less) & $\square$ & $\square$ & $\square$ & $\square$ & $\square$ & $\square$ & $\square$ & $\square$ & $\square$ & $\square$ \\
\hline
\end{tabular}

Page 5 


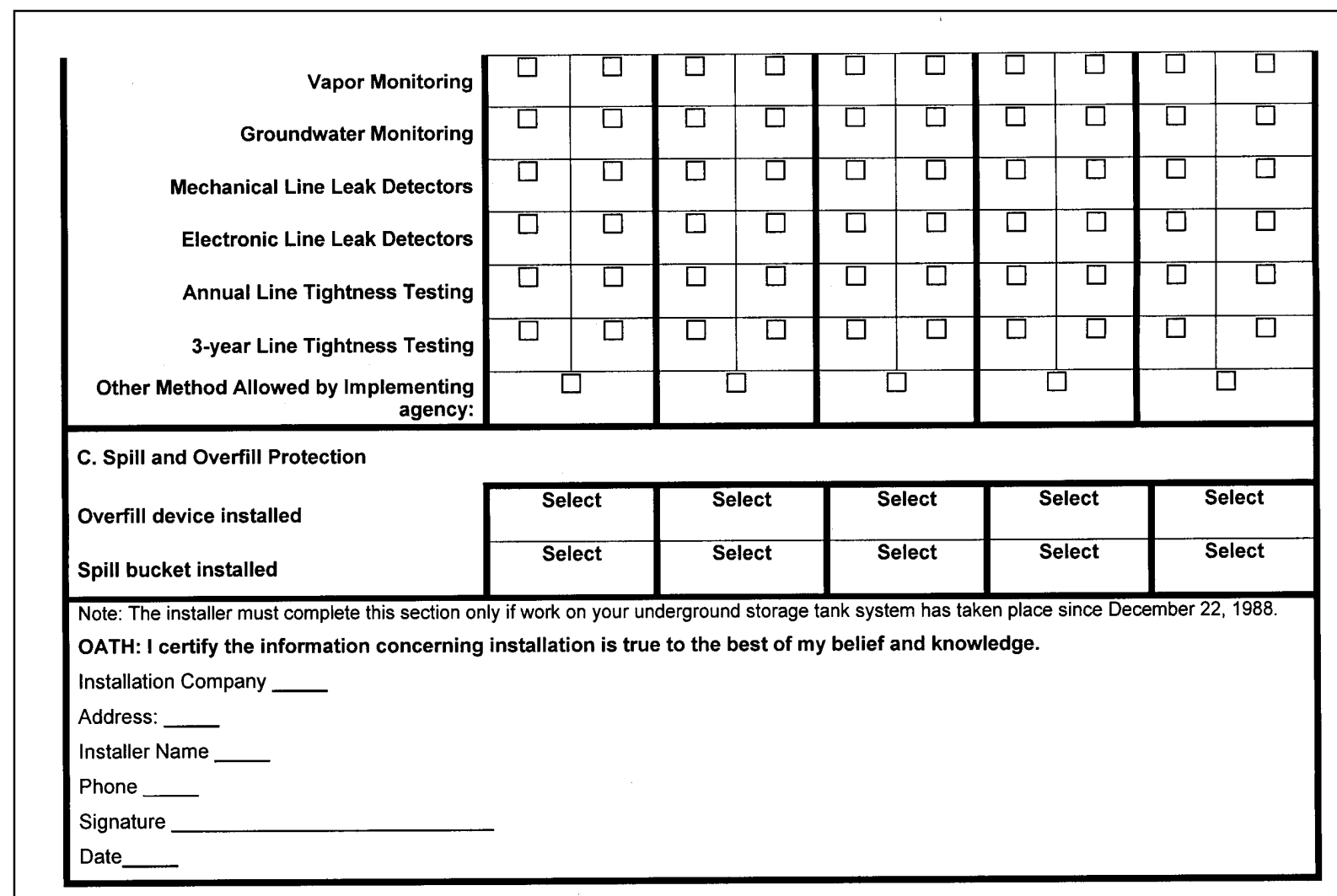

Page 6 


\section{Appendix B \\ CCN 224670, Sampling and Analysis Plan}

July 8,2011

CCN 224670

Kristi Lowder

UST Coordinator

Idaho Department of Environmental Quality

1410 North Hilton

Boise, ID 83706

SUBJECT: Sampling and Analysis Plan for the Underground Storage Tank Closure at Idaho National Laboratory Test Area North

Dear Ms. Lowder:

This letter provides the Sampling and Analysis Plan (SAP) for permanent closure of an underground storage tank located at Idaho National Laboratory Test Area North (Site 3560 -6120044-17). This plan is submitted for Battelle Energy Alliance, LLC (BEA) as the operating contractor for this project. The 30-day closure notification was submitted on June 29, 2011 (CCN 224593). The attached SAP was requested by the Idaho Department of Environmental Quality (DEQ) Regional Office in Idaho Falls (S. Short, S. Heaton) during a telephone conversation on June 20,2011. The Idaho DEQ Regional Office also requested they be notified of the date the sampling will be performed so that they may be present. BEA will provide the Idaho DEQ Regional Office in Idaho Falls with a copy of this SAP and contact them by telephone to coordinate the sample date.

If you have any questions, please contact Brad Griffith at (208) 533-4530.

Sincerely,

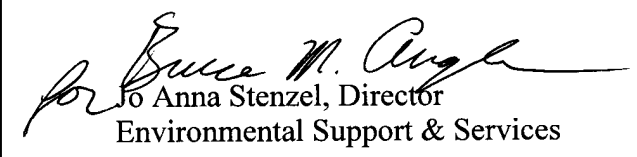

BKG:AT

Enclosure

P.O. Box 1625 • 2525 North Fremont Ave. • Idaho Falls, Idaho 83415 • 208-526-0111 • www.inl.gov Battelle Energy Alliance, LLC 
Ms. Kristi Lowder

July 8, 2011

CCN 224670

Page 2

cc: J. Alvarez, INL, MS 3695

P. K. Bowers, DOE-ID, MS 1226

R. R. Chase, INL, MS 3695

S. D. Dossett, INL, MS 3405

J. J. Grossenbacher, INL, MS 3695

R.A. Gallegos, DOE-ID, MS 1216

S. Heaton, DEQ, Idaho Falls

C. D. Melbihass, INL, MS 3406

S. M. Olson, DOE-ID, MS 1240

T. L. Perkins, DOE-ID, MS 1216

S. Short, DEQ, Idaho Falls

D. M. Storms, INL, MS 3888

J. R. Sturm, DOE-ID, MS 1216 
Ms. Kristi Lowder

July 8, 2011

CCN 224670

Page 3

bcc: T. L. Carlson, MS 3405 Tre

C. Barnhart, MS 0302

J. F. Graham, MS $3428 \sqrt{\text { H6 }}$

B. K. Griffith, MS 7113 .

S. D. Lee, MS 3405

T. A. Miller, MS 3428

R. V. Nelson, MS 3406

N. E. Stanley, MS 4131

D. W. Wagoner, MS 3405

INL Correspondence Control, MS 3640, email: BEACC@inl.gov

Environmental Correspondence, MS 3405, email: ENVAFF@inl.gov

J. A. Stenzel Letter Log (JAS-55-11))

Uniform File Code: $\underline{5163}$

Disposition Authority: ENV1-d-13

Retention Schedule: Cut off annually. Destroy after 75 years

NOTE: Original disposition authority, retention schedule, and Uniform Filing Code applied by the sender may not be appropriate for all recipients. Make adjustments as needed. 


\section{Sampling and Analysis Plan for the Closure of TAN-664 Fuel Tank}

The INL is a U.S. Department of Energy National Laboratory operated by Battelle Energy Alliance.

Idaho National

Laboratory 


\section{CONTENTS}

..ii

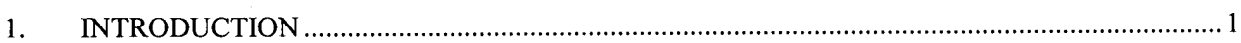

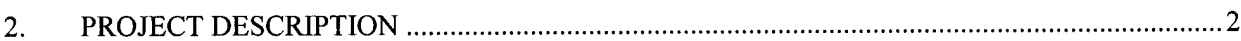

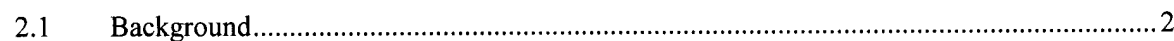

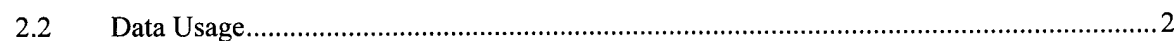

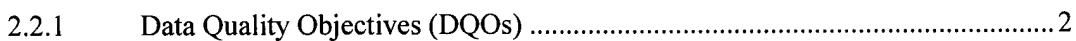

2.2.2 Measurement Quality Objectives ..................................................................... 4

$2.3 \quad$ Sample Collection and Documentation ........................................................................ 4

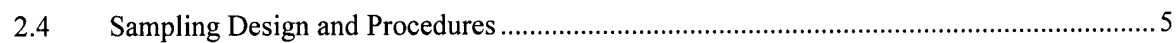

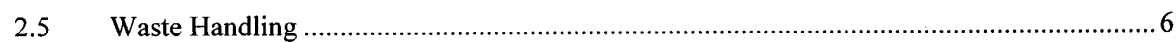

3. DATA QUALITY REQUIREMENTS AND ASSESSMENTS …............................................. 6

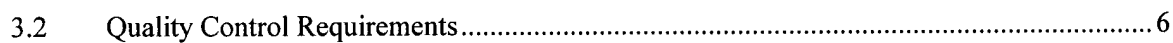

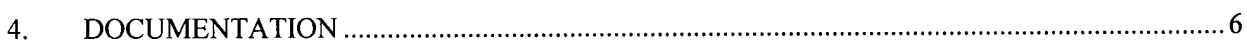

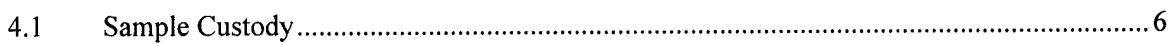

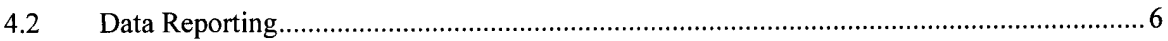

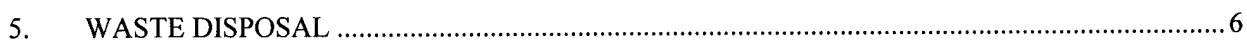

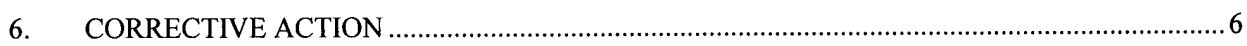

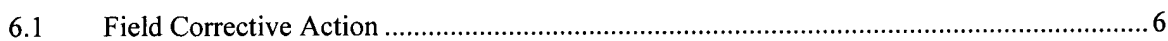

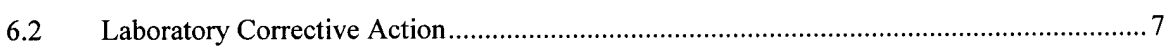

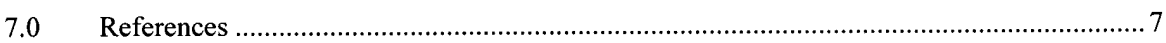

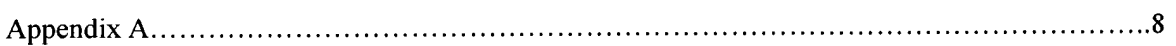




\section{ACRONYMS}

$\begin{array}{ll}\text { AA } & \text { Alternative Actions } \\ \text { CFR } & \text { Code of Federal Regulations } \\ \text { CI } & \text { Confidence Interval } \\ \text { COC } & \text { chain of custody } \\ \text { DEQ } & \text { Idaho Department of Environmental Quality } \\ \text { DI } & \text { Deionized Water } \\ \text { DOE-ID } & \text { Department Of Energy-Idaho } \\ \text { DQO } & \text { data quality objectives } \\ \text { DS } & \text { Decision Statement } \\ \text { EPA } & \text { Environmental Protection Agency } \\ \text { GDE } & \text { Guide } \\ \text { IH } & \text { industrial hygienist } \\ \text { INL } & \text { Idaho National Laboratory } \\ \text { LI } & \text { Laboratory Instructions } \\ \text { MCP } & \text { management control procedure } \\ \text { MQO } & \text { Measurement Quality Objective } \\ \text { MS/MSD } & \text { matrix spike/matrix spike duplicate } \\ \text { P/A } & \text { precision/accuracy } \\ \text { POD } & \text { Plan of the Day } \\ \text { PSQ } & \text { Principal Study Question } \\ \text { QA } & \text { quality assurance } \\ \text { QC } & \text { quality control } \\ \text { RCRA } & \text { Resource Conservation Recovery Act } \\ \text { RCT } & \text { radiological control technician } \\ \text { RDL } & \text { contract required detection limit } \\ \text { RWP } & \text { Radiation Work Permit } \\ \text { SAP } & \text { Sampling and Analysis Plan } \\ \text { SOW } & \text { statement of work } \\ \text { TAL } & \text { target analyte list } \\ \text { TAN } & \text { Test Area North } \\ \text { TAT } & \text { turn around time } \\ \text { TOS } & \text { task order work statement } \\ \text { UTS } & \text { Universal Treatment Standards (from RCRA land disposal regulations) } \\ \text { WGS } & \text { Waste Generator Services } \\ \text { WTS } & \text { Waste Technical Specialist } \\ & \end{array}$




Idaho National Laboratory
\begin{tabular}{|c|lll|}
\hline $\begin{array}{c}\text { SAMPLING AND ANALYSIS PLAN FOR THE } \\
\text { CLOSURE OF TAN-664 FUEL TANK }\end{array}$ & $\begin{array}{l}\text { Identifier: } \\
\text { Revision: } \\
\text { Effective Date: }\end{array}$ & $07 / 08 / 2011$ & Page: 1 of 9 \\
\hline
\end{tabular}

\section{INTRODUCTION}

TAN - 664 fuel tank is listed in the INL Tank Inventory as 98TAN00491, the operator is Battelle Energy Alliance, one of the current contractors at the INL. The tank is \#6-120044-17 in the Idaho Dept. of Environmental Quality (DEQ) UST database (Site ID=3560). Map-1 in appendix A shows the tank location. The project completed the UST Notification Form on 06/29/2011 and submitted it to Kristi Lowder, UST Coordinator for IDEQ. The DEQ Idaho Falls office was given a copy on 6/30/2011. The DEQ Idaho Falls office (S. Heaton, S. Short) was also contacted by phone on 6/20/2011 at which time they indicated they would like to review the Sampling and Analysis Plan for the closure and be present during the sampling activity. The DEQ Idaho Falls office will be notified prior to sampling and 48 hours prior to actual closure. A revised signed UST Notification Form for the closure will be submitted after receiving the site assessment results.

This tank is a 15,000 gallon fiberglass reinforced plastic underground storage tank installed in 1991. The tank contained gasoline; on 2/17/11 Howard Pugmire confirmed via telecon that the tank was used for unleaded gasoline only. On 6/08/11, Leonard Petroleum contracted with Conrad and Bischoff to transfer the remaining fuel in the TAN Gasoline UST to other tanks at the INL. They drained all the fuel out of the line from the dispenser to the tank and pumped the remaining fuel out of the tank into a fuel truck. This fuel was taken to various other tanks around the INL. Leonard Petroleum personnel (Joe Browning) can confirm this activity and invoice \#28051C provides documentation. The last passing CSLD result was on that day (6/08/11). The UST met all the requirements for temporary closure per 40 CFR 280.70 at that time. This SAP will outline the sampling to be performed before the tank is permanently closed. The roles and responsibilities are listed in Table 1 of the people who will be involved in this tank closure project.

Table-1 Roles and responsibilities.

\begin{tabular}{|c|c|c|}
\hline Title/Organization & Name & Responsibilities \\
\hline Project Manager & Roderick V. Nelson & $\begin{array}{l}\text { Project execution and completion, } \\
\text { budgets and schedules }\end{array}$ \\
\hline Facility Supervisor & Jerry Pruett and Tom Haynes & $\begin{array}{l}\text { Approves and schedules sampling } \\
\text { activities in the TAN Facility }\end{array}$ \\
\hline Environmental Compliance & Brad Griffith & Coordinate UST closure activity. \\
\hline Sampling Team & Trained TSD staff & $\begin{array}{l}\text { Practice behavior-based safety (BBS), } \\
\text { collect samples, minimize exposure, } \\
\text { and minimize waste generation. }\end{array}$ \\
\hline Environmental Monitoring & $\begin{array}{l}\text { Scott Lee, Peggy Scherbinske, } \\
\text { Michael Towler }\end{array}$ & $\begin{array}{l}\text { Write SAP, develop lab contract, } \\
\text { package and ship samples. }\end{array}$ \\
\hline Industrial Hygiene & To be Determined & Health and safety \\
\hline Radiation Control & To be Determined & Radiation Control 752 Office \\
\hline Waste Generator Services & Marshall Marlor & Ensure waste is handled properly \\
\hline Packaging and Transportation & Robert Flores, Michael Towler & $\begin{array}{l}\text { Ensure samples are properly packaged } \\
\text { for shipment }\end{array}$ \\
\hline
\end{tabular}




\begin{tabular}{|l|lll|}
\hline $\begin{array}{l}\text { SAMPLING AND ANALYSIS PLAN FOR THE } \\
\text { CLOSURE OF TAN-664 FUEL TANK }\end{array}$ & $\begin{array}{l}\text { Identifier: } \\
\text { Revision: } \\
\text { Effective Date: }\end{array}$ & $07 / 08 / 2011$ & Page: 2 of 9 \\
\hline
\end{tabular}

Laboratory Analysis

State Certified Contract

Laboratory (i.e., Test America

Sample analyses, minimum detection

Laboratories or equivalent) limits achieved

\section{PROJECT DESCRIPTION}

\subsection{Background}

TAN- 664 fuel tank is scheduled to be permanently closed. The tank is a fiberglass reinforced plastic underground storage tank installed in 1991. The dimensions of the tank are 10'4" in diameter X 29' 5 " in length and have a capacity of 15,000 gallons. It will be closed in place and filled with grout instead of being removed from the ground. Because the tank was used for unleaded gasoline the analytes of interest are benzene, toluene, ethyl benzene, xylenes (BTEX), MTBE, and naphthalene (from Table 800.01 of IDAPA 58.01.24). An estimated four soil samples will be collected to verify that the content of the tank has not leaked out over time. Three samples will be collected below the bottom of the tank: one on each end and one on the South side the tank. One soil sample will be collected below the piping near the dispenser. All samples will represent the native material below the tank installation. The first 1 foot of the native material will be targeted for the sample collection.

\subsection{Data Usage}

The analytical results from the samples will be used to verify the integrity of tank and that the native material is free of petroleum contaminates. The overall goal is to provide substantial data to the Agencies involved to show that the site assessment requirements for UST closures have been met.

\subsubsection{Data Quality Objectives (DQOS)}

The objective of this sampling activity is to obtain analysis from representative samples of native soils for comparison with the State screening levels for petroleum products. The data quality objectives (DQO) process is used to specify, qualitatively and quantitatively, the objectives for the data collected. The DQO process is described in the Environmental Protection Agency (EPA) documents Guidance for the Data Quality Objectives Process (EPA-QA/G4) and in Data Quality Objectives for Hazardous Waste Site Investigations (EPA QA/G-4HW). The DQO process has several steps, each of which has specific outputs. Each of the following subsections corresponds to a step in the DQO process, and the output for each step is provided as appropriate.

\subsubsection{Decision Statement}

This step in the DQO process is used to identify the principal study questions (PSQs) and alternative actions (AAs) that could result from resolution of the PSQs, and to combine the PSQs and AAs into decision statements.

The objective of this waste characterization activity is to answer the following principal study question:

PSQ: Are the concentrations of the contaminants of concern in the native soil below the State screening levels? 


Idaho National Laboratory
\begin{tabular}{|c|l|l|}
\hline $\begin{array}{c}\text { SAMPLING AND ANALYSIS PLAN FOR THE } \\
\text { CLOSURE OF TAN-664 FUEL TANK }\end{array}$ & $\begin{array}{l}\text { Identifier: } \\
\text { Revision: } \\
\text { Effective Date: } 07 / 08 / 2011\end{array}$ \\
\hline
\end{tabular}

The alternative actions to be taken based on resolution of the PSQ are:

AA: If the contaminant concentrations are below the State screening levels then the area will be considered to meet the State closure performance standards and the documentation will be maintained in the facility operating files to support future closure. If concentrations are above the State screening levels then the tank will need to be removed and cleanup activities will be needed. Sampling will be performed once the cleanup is done to show the State Screening Levels are being met and concentrations are below the EQLs.

Combing the PSQ and AA results in the following decision statement (DS):

DS: $\quad$ Determine whether the tank in question can be closed in place or if it needs to be removed for cleanup activities.

\subsubsection{Decision Inputs}

The purpose of this step is to identify informational inputs that will be required to resolve the decision statement and determine which inputs require measurements. The information needed to resolve the decision statement listed above is the identification and quantification of the State Screening Limits for the targeted analyte. During this step of the DQO process the basis for an action level is established. The action level is the threshold value that provides the criterion for choosing between alternative actions. Action levels may be based on regulatory thresholds or standards, or they may be derived from problemspecific considerations such as risk analysis.

\subsubsection{Study Boundaries}

This step in the DQO process defines the spatial and temporal boundaries of the study covered by the decision statement. Defining the spatial boundaries involves specification of characteristics that define the population of interest, defining the physical extent of the study area, and may include subdividing the population of interest into specific areas (or strata) of interest. The temporal boundaries define the duration of the study, or specific parts of the study. The appropriate outputs of this step are a detailed description of the spatial and temporal boundaries of the problem and a discussion of any practical constraints that may interfere with the study. The study boundary for this SAP is the area directly under and around the tank. Soil grab samples for benzene, toluene, ethyl benzene, and xylenes (BTEX), MTBE, and naphthalene will be collected from native soils under the tank to determine whether contaminants are present.

\subsubsection{Decision Rule}

The objective of this step is to define the parameters of interest that characterize the population, specify the action level, and integrate previous DQO outputs into a single statement that defines the conditions that would cause the decision maker to choose among alternative actions. The decision rule typically takes the form of an "If...then" statement describing the action to take if one or more conditions are met. If inorganic contaminant concentrations in the transfer line are above the State screening levels then additional decontamination will be performed until verification samples confirm that concentrations are below the State screening levels. 
Measurement Quality Objectives (MQOs) are specifications for precision, accuracy, and completeness that measurements must meet to produce acceptable data.

The laboratory evaluates the accuracy of the analyses with an internal laboratory QA/QC program utilizing matrix spikes. The accuracy goals established by the laboratory will be considered acceptable for this project. The completeness goal for this project is $100 \%$ which means all samples will be collected and all analysis will be acceptable and contain no rejected data.

The laboratory will perform initial data reduction and data quality review. In addition, validation to Level B will be performed by an outside validator. Level B validation includes a check of the following, at a minimum:

- Chain of Custody

- Requested versus reported analyses

- Analysis holding times

- Method blank criteria (e.g. contamination)

- Matrix spike/matrix spike duplicate recoveries/precision (MS/MSD)

- Duplicate sample precision

- Surrogate spike recoveries

The required sample bottles, preservation, and holding times are in Table 2.

\subsection{Sample Collection and Documentation}

Collection of the samples will be conducted using the work control process. Specifically LI-328 AND LI-114 will be used to identify the hazards and mitigations, training, and PPE. In the case of finding something unexpected while sampling(RAD, Organic vapors,) "a stop work "will be instituted, the LI directs you to key personnel to assess the new hazards(IH,RCT). Collection of the samples, decontamination, shipment, labeling, and chain of custody, will follow MCP, LI, and/ or guides (GDEs) as identified below.

LWP-9101, "INL Procedure Usage"

GDE-9103 "Conduct of Operations Guidance for Communications"

MCP-8523, "Management of Hazardous and Nonhazardous Samples"

LI-359, "Cleaning of Environmental Monitoring Services Sampling Equipment"

LI-335, "Working in an Environmental Monitoring Sample Preparation Area"

LI-328, "Umbrella Sampling Plan" 


\begin{tabular}{|l|l|l|l|}
\hline $\begin{array}{c}\text { SAMPLING AND ANALYSIS PLAN FOR THE } \\
\text { CLOSURE OF TAN-664 FUEL TANK }\end{array}$ & $\begin{array}{l}\text { Identifier: } \\
\text { Revision: } \\
\text { Effective Date: }\end{array}$ & $07 / 08 / 2011$ & Page: 5 of 9 \\
\hline
\end{tabular}

LI-114, "Use of the PowerProbe"

Samples will be numbered using the prefix "BEA" followed by a unique six digit number. The sample numbers, labels and Chain of Custody (COC) forms will be generated in the SAP Application program by Environmental Site Services personnel. Field activities for this sampling event will be documented in the non-routine logbook INL-NR-006.

\subsection{Sampling Design and Procedures}

The two sampling methods that will be available for sample collection from below the tank are the use of a hand auger and/or the use of the PowerProbe direct push sampler. The hand auger will be the method of preference and will be tried first. LI-328 explains in detail the use of the hand auger for collecting soil samples and is the procedure that will be followed when the hand auger is being used. LI114 explains in detail the use of the PowerProbe for sampling soil and is the procedure that will be followed when the PowerProbe is being used. Each of the LIs that will be used list the hazards associated with each sampling method, it also contains a list of the mitigations of the hazards. The tank is $10.5^{\prime}$ in diameter, the top of the tank is 3' below ground surface, and there is a minimum of 12 " bed of gravel below the tank. With both sampling methods we will auger down until we find native soil instead of the gravel tank bed and then collect the sample from the first 1' of soil. The depth to be sampled is approximately from $14.5^{\prime}$ to $15.5^{\prime}$ ' below ground surface. We are able to use a smaller diameter auger since the required volume of sample material is only $125 \mathrm{ml}$ per sampling location. The sampling tools will be completely deconned prior to use at each separate sampling location. The required number of samples for this tank abandonment will be four, one at each end of the tank, one at the center line of the tank on the south side, and one under the piping near the dispenser. See Map-2 in Appendix A for tank orientation and sample location. The sample bottle requirements, analysis, preservation, and holding times are listed below in Table 2. Once the sample is collected it will be transferred to the correct bottle, the bottle will be labeled, sealed, and placed on ice for preservation. The samples will be taken to MFC-721 SPA for packaging for transport to the lab.

Table-2 Sample bottle requirements, analysis, preservation, and holding times.

\begin{tabular}{|c|l|l|l|l|l|l|}
\hline Sample location & Type & \multicolumn{1}{|c|}{ Analyte } & Method & $\begin{array}{c}\text { Bottle } \\
\text { Volume/type }\end{array}$ & Preservative & Holding time \\
\hline 1 & $\begin{array}{l}\text { Grab } \\
\text { Sample }\end{array}$ & $\begin{array}{l}\text { BTEX with MTBE } \\
\text { and Naphthalene }\end{array}$ & $\begin{array}{l}\text { SW-846 } \\
8260 \mathrm{~B}\end{array}$ & $125 \mathrm{ml} \mathrm{AG}$ & Cool, 4 deg. C & 14 Days \\
\hline 2 & $\begin{array}{l}\text { Grab } \\
\text { Sample }\end{array}$ & $\begin{array}{l}\text { BTEX with MTBE } \\
\text { and Naphthalene }\end{array}$ & $\begin{array}{l}\text { SW-846 } \\
8260 \mathrm{~B}\end{array}$ & $125 \mathrm{ml} \mathrm{AG}$ & Cool, 4 deg. C & 14 Days \\
\hline 3 & $\begin{array}{l}\text { Grab } \\
\text { Sample }\end{array}$ & $\begin{array}{l}\text { BTEX with MTBE } \\
\text { and Naphthalene }\end{array}$ & $\begin{array}{l}\text { SW-846 } \\
8260 \mathrm{~B}\end{array}$ & $125 \mathrm{ml} \mathrm{AG}$ & Cool, 4 deg. C & 14 Days \\
\hline 4 & $\begin{array}{l}\text { Grab } \\
\text { Sample }\end{array}$ & $\begin{array}{l}\text { BTEX with MTBE } \\
\text { and Naphthalene }\end{array}$ & $\begin{array}{l}\text { SW-846 } \\
8260 \mathrm{~B}\end{array}$ & $125 \mathrm{ml} \mathrm{AG}$ & Cool, 4 deg. C & 14 Days \\
\hline
\end{tabular}




\subsection{Waste Handling}

All sampling derived waste will be handled according to instructions from Marshall Marlor in Waste Generator Services (WGS).

\section{DATA QUALITY REQUIREMENTS AND ASSESSMENTS}

\subsection{Data Completeness and Representativeness}

All samples collected during this activity will be prepared and analyzed according to guidelines set forth in the laboratory contract. It is imperative that the designated laboratory performs the analysis using these techniques to ensure quality, precision, accuracy, and completeness of the data. All sample collecting, handling, and selecting of analytical protocols have been chosen so the results will be as representative as possible of the media and conditions being measured.

\subsection{Quality Control Requirements}

QC has been discussed in Section 2.

\section{DOCUMENTATION}

\subsection{Sample Custody}

Full chain of custody will be maintained at all times, as specified in MCP-8523.

\subsection{Data Reporting}

All analytical results, $\mathrm{COC}$, and QC measurements for each sample analyzed will be required from the laboratory with an expedited seven day Turn Around Time (TAT). Data will be forwarded to:

Peggy Scherbinske, BEA, via E-mail.

\section{WASTE DISPOSAL}

Any waste generated during sampling is the responsibility of the WGS. It is anticipated that discarded sampling equipment (lexan liners, decon towels, PPE) will be treated as waste until the analytical results can be reviewed to determine the proper waste disposal.

\section{CORRECTIVE ACTION}

Corrective actions are required whenever established control limits for an analysis are exceeded. Documentation of such corrective action is required and will be addressed in the final report.

\subsection{Field Corrective Action}

The initial responsibility for monitoring the quality of field measurements lies with the field personnel. If a problem occurs that might jeopardize the integrity of the project, result in failure to meet QA objectives, or impact data quality, the project manager will immediately contact the project requester. 


\begin{tabular}{|l|l|l|}
\hline $\begin{array}{c}\text { SAMPLING AND ANALYSIS PLAN FOR THE } \\
\text { CLOSURE OF TAN-664 FUEL TANK }\end{array}$ & $\begin{array}{l}\text { Identifier: } \\
\text { Revision: } \\
\text { Effective Date: }\end{array}$ 07/08/2011 & Page: 7 of 9 \\
\hline
\end{tabular}

The project manager will document the situation, the field objectives affected, the corrective actions taken, and the results of that action. Copies of documentation will be provided to the project requester. Corrective action will be implemented when the project objectives are not met or when conditions adverse to quality have been identified. Conditions adverse to quality shall be promptly identified and corrected as soon as possible. The identification, cause and corrective action to prevent reoccurrence shall be determined and documented for significant conditions adverse to quality.

\subsection{Laboratory Corrective Action}

The laboratory corrective action plan will be detailed in the laboratory quality program plan. The need for corrective action may come from several sources: equipment malfunctions, failure of internal QC checks, blank contamination, failure of performance or system assessments, and noncompliance with QA requirements. Laboratory measurement equipment or analytical methods that fail to meet project $\mathrm{QC}$ requirements will be immediately brought to the attention of the laboratory $\mathrm{QC}$ manager. If failure is due to the equipment malfunctioning, the equipment will be repaired and re-calibrated and the analysis repeated. All attempts will be made to repeat all affected parts of the analysis so that the end product will not be affected by failure to meet QC requirements. Nonconforming data will be qualified with a note specifying any reasons for the qualification. All incidents of failure to meet QC requirements and all corrective actions will be documented.

Corrective action reports will be immediately implemented for deficiencies noted during checks of raw data. This action will vary depending upon problems noted, and can range from correcting miscalculated data to requiring reanalysis of samples. As soon as sufficient time has elapsed for corrective action to be implemented, evidence of corrective action will be presented. Documentation of corrective action measures will be forwarded to the project manager. Corrective action documentation will include the following: a discussion of the nature of the problem, date and time of discovery, parameters affected, sample lot affected, date, time, and description of the resulting corrective action and signature of the complying manager.

The laboratory QA officer will prepare a written report on corrective action for the project manager. The report will review the validity, quality, and completeness of the data in question and if necessary make recommendations for corrective action.

\subsection{References}

LWP-9101, "INL Procedure Usage"

GDE-9103, "Conduct of Operations Guidance for Communications"

MCP-8523, "Management of Hazardous and Nonhazardous Samples"

LI-359, "Cleaning of Environmental Monitoring Services Sampling Equipment"

LI-335, "Working in an Environmental Monitoring Sample Preparation Area"

LI-328, "Umbrella Sampling Plan"

LI-114, "Use of the PowerProbe" 


\section{Appendix A}

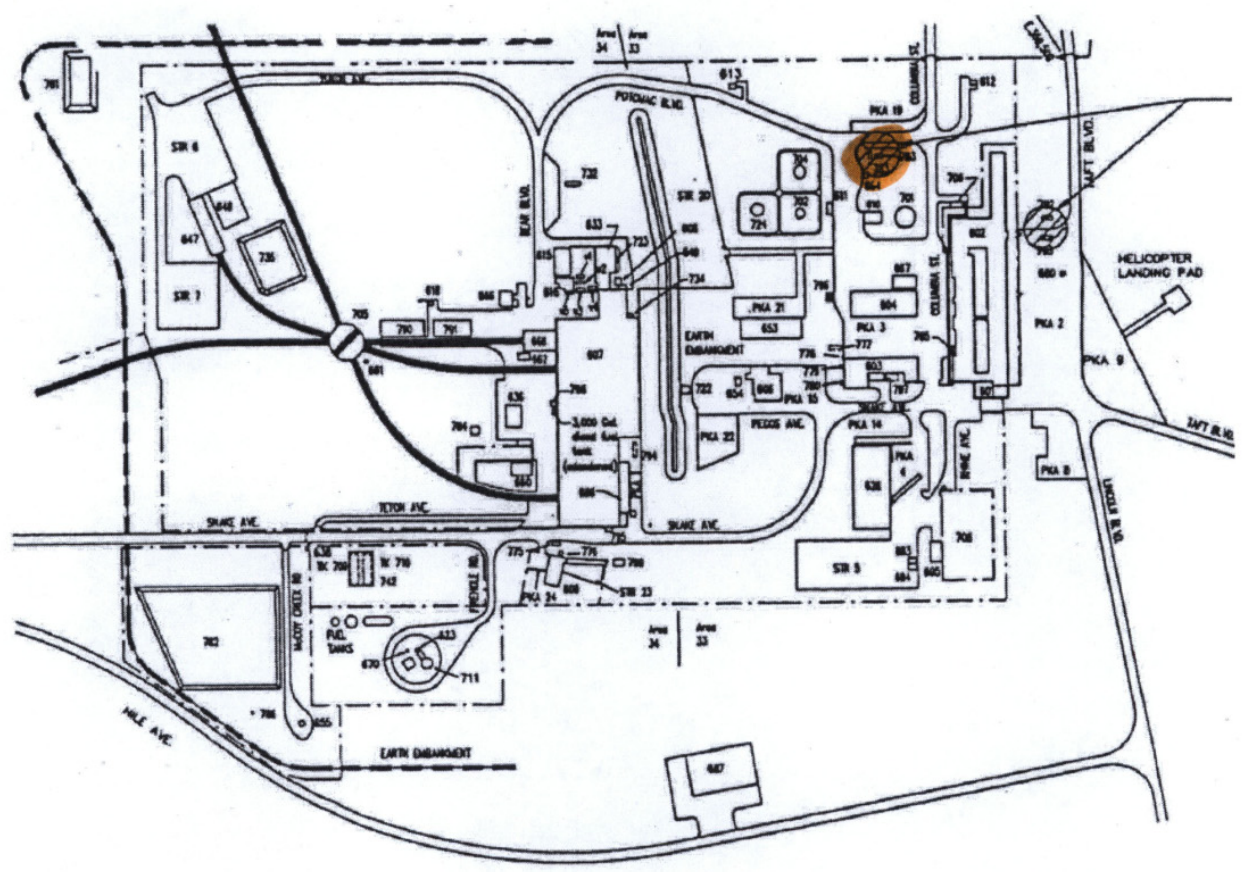

TAN/TSF AREA MAP

Map-1 Plan Map of TAN Area 


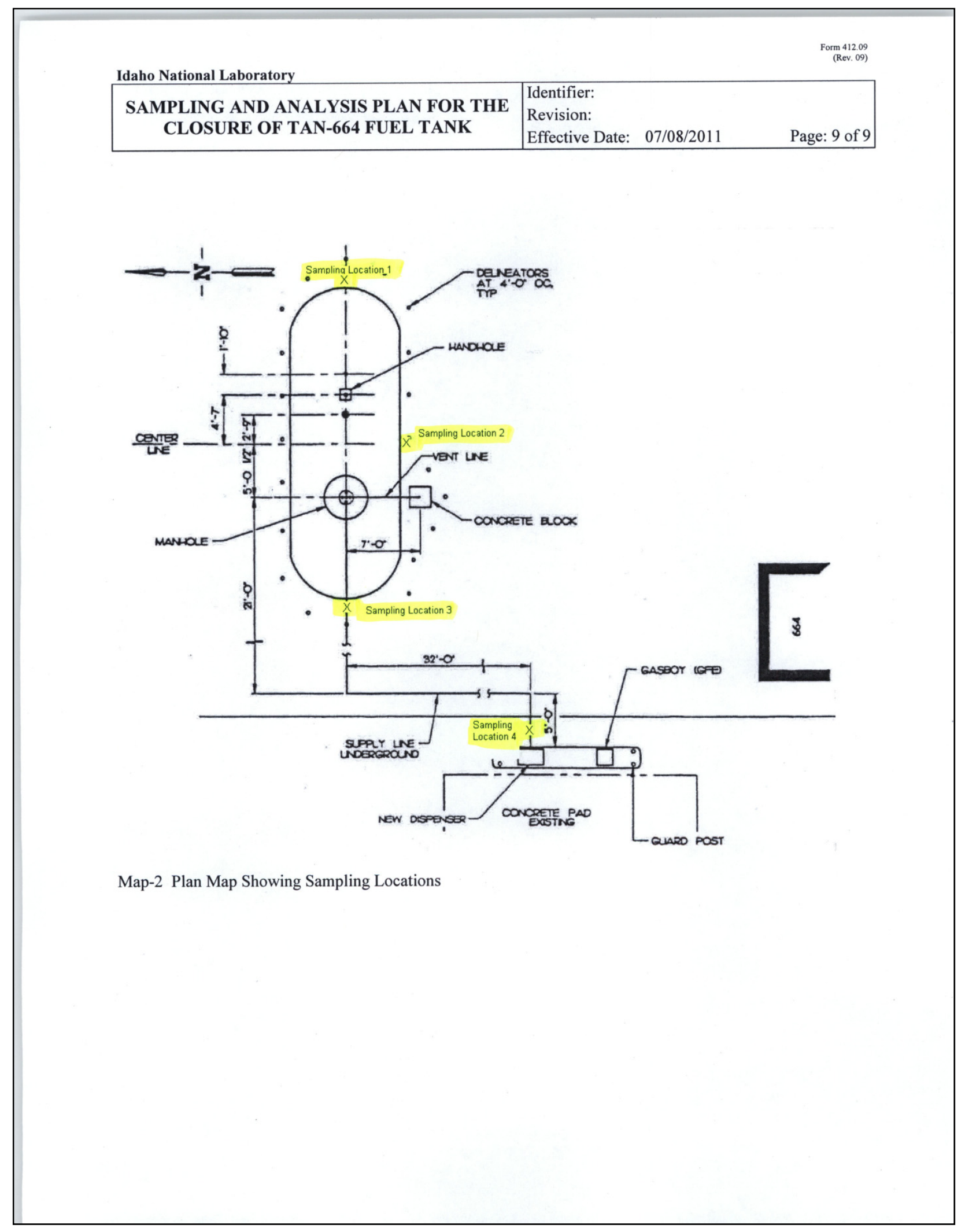




\section{Appendix C CCN 225390, Sample Analytical Report}

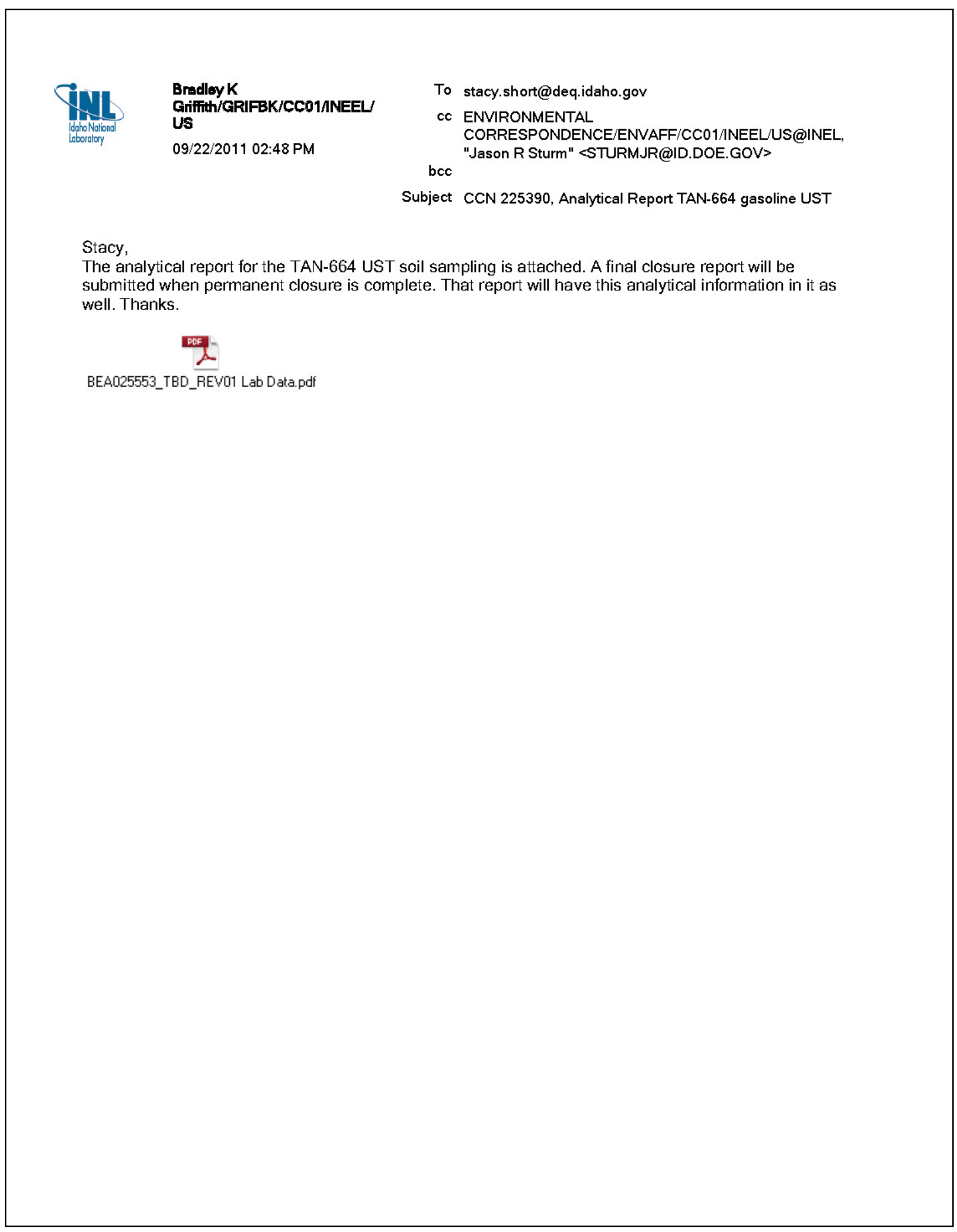




\title{
TestAmerica \\ THE LEADER IN ENVIRONMENTAL TESTING
}

\section{Analytical Report}

Battelle Energy Alliance

SDG: BEA025553 TBD

Laboratory Report Identification: F1G200464

(REVISED)

BEA-SOW-8500, Rev. 4

TOS-A1147 / TAN-664 Fuel Tank Soil Sampling

\author{
Laboratory Identification \\ TestAmerica - St. Louis \\ 13715 Rider Trail North \\ Earth City, MO 63045 \\ (314) $298-8566$
}

I certify that this data package is in compliance with the terms and conditions of BEA-SOW-8500, Rev. 4 and any applicable TOSs for this project both technically and for completeness, for other than the conditions detailed in this case narrative. Release of the data contained in this data package and also in any associated computer-readable data submitted has been authorized by the laboratory manager or manager's designee.

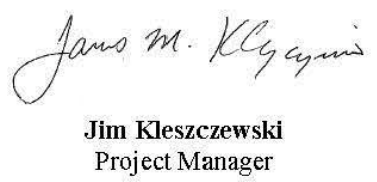

July 28, 2011 


\section{Case Narrative}

\begin{tabular}{ll}
\hline $\begin{array}{l}\text { SDG Number: } \\
\text { Statement of Work Number: }\end{array}$ & $\begin{array}{l}\text { BEA025553_TBD } \\
\text { BEA-SOW-8500, Rev. } 4 \\
\text { Project Name: }\end{array}$ \\
\hline & TOS-A1147/ TAN-664 Fuel Tank Soil Sampling \\
\hline
\end{tabular}

This is a revised report. The reporting limits for the compounds analyzed by $\mathrm{SW846} 8260 \mathrm{~B}$ have been corrected.

All applicable quality control procedures met method-specified acceptance criteria except as noted below..

The test results in this report meet all NELAP requirements for parameters for which accreditations are held by TestAmerica -St. Louis. Any exceptions to NELAP requirements are noted in the case narrative. The case narrative is an integral part of this report. This report shall not be reproduced except in full, without the written approval of the laboratory. This report is incomplete without the case narrative. All results are based upon sample as received, wet weight, unless noted otherwise.

\section{Shipping and Receiving}

Reference the chain of custody and condition upon receipt report for any variations on receipt conditions and temperature of samples on receipt.

\section{Observations/Nonconformances}

\section{Volatiles by SW846 8260B}

Batch: 1206129

The CCV \%Ds for Acrolein and Nonanal are outside the established QC limits. These analytes are not part of the analysis request and thus this excursion does not affect the data.

Affected Samples:

F1G200464 (1): BEA025553 TBD $\quad$ F1G200464 (3): BEA025556 TBD

F1G200464 (2): BEA025554_TBD F1G200464 (4): BEA025557_TBD 


\section{METHODS SUMMARY}

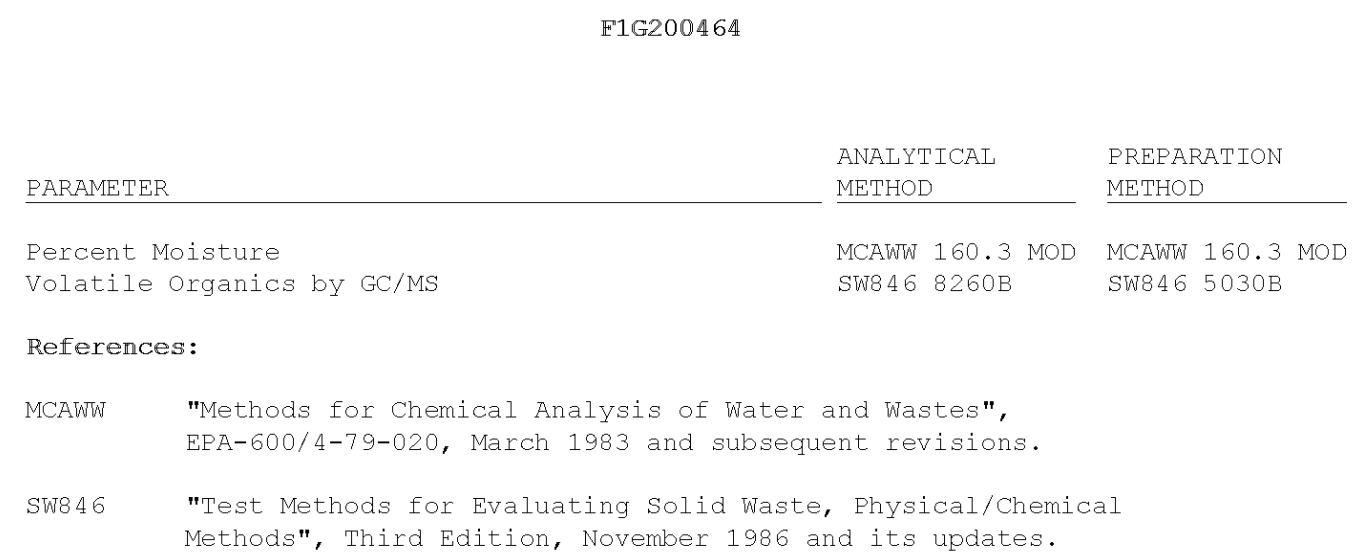




\section{SAMPLE SUMMARY}

Fn"1G200464

WO \# SAMPLE\# CLIENT SAMPLE ID

SAMPLED SAMP DATE $\underline{\text { TIME }}$

MK2L5 $001 \quad$ BEA025553 TBD

MK2L $6 \quad 002 \quad$ BEA025554 TBD

MK2L $7 \quad 003 \quad$ BEA025556 TBD

MK2L日 $004 \quad$ BEA025557 TBD

$07 / 18 / 11 \quad 12: 15$

$07 / 18 / 1114: 15$

$07 / 18 / 1114: 55$

$07 / 18 / 11 \quad 15: 10$

NOTEU

- The analytical results of the samples listed above are presented on the following pages.

- All calculations are performed before rounding to avoid round-off errors in calculated results.

- Results noted as "ND" were not detected at or above the stated limit.

- This report must not be reproduced, except in full, without the written approval of the laboratory.

- Results for the following parameters are never reported on a dry weight basis: color, corrosivity, density, flashpoint, ignitability, layers, odor,

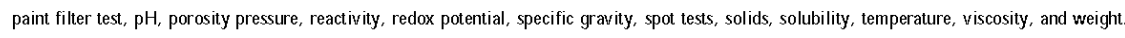


BEA-SOW-8500, REV.4

\title{
GC/MS SAMPLE AND QC DATA
}

\author{
Form I (s)
}

\author{
Volatile Organics
}


Lab Name:TestAmerica Laboratories, Inc. SDG Number:BEA025553_

Matrix: (soil/water) SOLID Lab Sample ID:F1G150469 001

Method: Sw846 $8260 \mathrm{~B}$

Volatile Organics, GC/MS (8260E)

Sample WT/Vol: $4.97 / 9$

Work Order: MKX8L1CH

Dilution factor: 1

Moisture $8: 18$

Client Sample Id: INTRA-LAB QC

Date Received: 07/15/11

Date Extracted:07/24/11

Date Analyzed: 07/24/11

QC Batch: 1206129

\begin{tabular}{|c|c|c|c|}
\hline CAS NO. & $\begin{array}{l}\text { CONCENTR } \\
\text { (ug/L or }\end{array}$ & $\begin{array}{l}\text { ATION UNITS: } \\
\mathrm{ug} / \mathrm{kg}) \mathrm{ug} / \mathrm{kg}\end{array}$ & $Q$ \\
\hline $71-43-2$ & Benzene & 6.1 & $\mathrm{U} \mid$ \\
\hline $100-41-4$ & Ethylbenzene & 6.1 & $\overline{\mathrm{U}} \mid$ \\
\hline $91-20-3$ & Naphthalene & 6.1 & $\overline{\mathrm{U}} \mid$ \\
\hline $108-88-3$ & Toluene & 6.1 & $\overline{\mathrm{U}} \mid$ \\
\hline $95-47-6$ & o-Xylene & 6.1 & $\overline{\mathrm{U}} \mid$ \\
\hline $136777-61-2$ & m-Xylene \& p-Xylene & 6.1 & $\overline{\mathrm{U}} \mid$ \\
\hline $74-87-3$ & Chloromethane & 12 & $\overline{\mathrm{U}}$ \\
\hline $75-01-4$ & Vinyl chloride & 6.1 & $\overline{\mathrm{U}} \mid$ \\
\hline $74-83-9$ & Bromomethane & 12 & $\overline{\mathrm{U}} \mid$ \\
\hline $75-00-3$ & Chloroethane & 12 & $\overline{\mathrm{U}}$ \\
\hline $67-64-1$ & Acetone & 24 & $\mathrm{U} \mid$ \\
\hline $75-35-4$ & 1,1-Dichloroethene & 6.1 & $\overline{\mathrm{U}} \mid$ \\
\hline $75-09-2$ & Methylene chloride & 6.1 & $\overline{\mathrm{U}} \mid$ \\
\hline $75-15-0$ & Carbon disulfide & 6.1 & $\overline{\mathrm{U}} \mid$ \\
\hline $75-34-3$ & 1,1-Dichloroethane & 6.1 & $\overline{\mathrm{U}} \mid$ \\
\hline $78-93-3$ & 2-Butanone & 24 & $\overline{\mathrm{U}} \mid$ \\
\hline $540-59-0$ & 1,2-Dichloroethene (total) & 12 & $\overline{\mathrm{U}} \mid$ \\
\hline $67-66-3$ & Chloroform & 6.1 & $\bar{U} \mid$ \\
\hline $71-55-6$ & 1,1,1-Trichloroethane & 6.1 & $\overline{\mathrm{U}} \mid$ \\
\hline $56-23-5$ & Carbon tetrachloride & 6.1 & $\overline{\mathrm{U}} \mid$ \\
\hline $107-06-2$ & 1,2-Dichloroethane & 6.1 & $\bar{U} \mid$ \\
\hline $79-01-6$ & Trichloroethene & 6.1 & $\bar{U} \mid$ \\
\hline $78-87-5$ & 1,2-Dichloropropane & 6.1 & $\overline{\mathrm{U}} \mid$ \\
\hline $75-27-4$ & Bromodichloromethane & 6.1 & $\overline{\mathrm{U}} \mid$ \\
\hline $108-10-1$ & 4-Methyl-2-pentanone & 24 & $\overline{\mathrm{U}} \mid$ \\
\hline $10061-01-5$ & cis-1,3-Dichloropropene & 6.1 & $\overline{\mathrm{U}} \mid$ \\
\hline $10061-02-6$ & trans-1,3-Dichloropropene & 6.1 & $\bar{U}$ \\
\hline $79-00-5$ & 1,1,2-Trichloroethane & 6.1 & $\mathrm{U} \mid$ \\
\hline
\end{tabular}

EORM I 


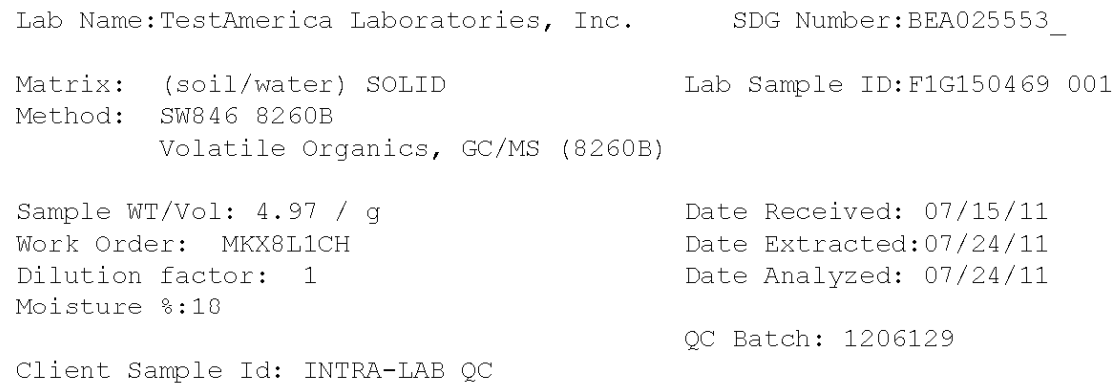

$\left|\frac{U}{\left|\frac{U}{U}\right|}\right|$




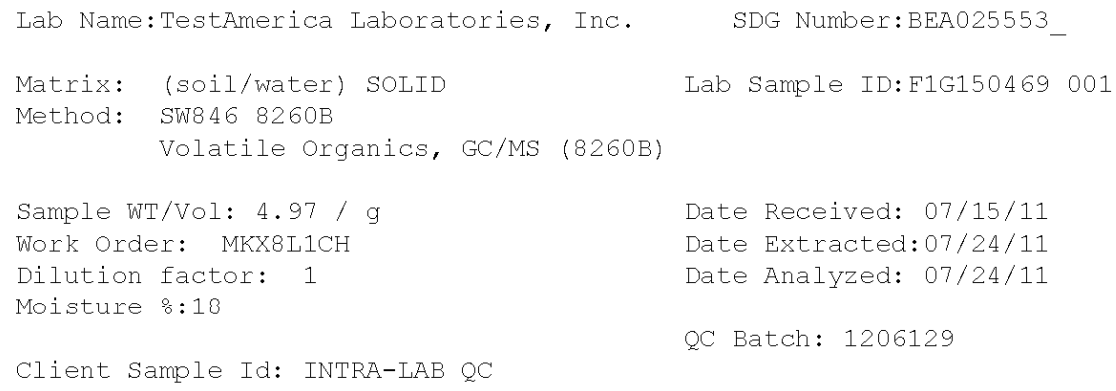

CAS NO. 60-29-7 $97-63-2$ $76-13-1$ $87-68-3$ $110-54-3$ $98-82-8$ $99-87-6$ $80-62-6$ $79-46-9$
COMPOUND ( $\mathrm{ug} / \mathrm{L}$ or $\mathrm{ug} / \mathrm{kg}$ ) ug/kg Ethyl ether 112 Ethyl methacrylate Freon 113

Hexach lorobutadiene n-Hexane

Isopropylbenzene 4-Isopropyltoluene Methyl methacrylate 2-Nitropropane n-Propylbenzene 1,1,1,2-Tetrach loroethane Tetrahydrofuran 1,2,3-Trichlorobenzene 1,2,4-Trichlorobenzene Trichlorofluoromethane 1,3,5-Trimethylbenzene 1-Butanol Acetonitrile Ethyl acetate 2-Chloroethyl vinyl ether Iodomethane Vinyl acetate Acrolein Acrylonitrile Cyclohexane Isobutanol Methacrylonitrile Methylcyclohexane

\begin{tabular}{|c|c|}
\hline 112 & \\
\hline 6.1 & \\
\hline 6.1 & \\
\hline 6.1 & \\
\hline 12 & \\
\hline 6.1 & \\
\hline 6.1 & \\
\hline 6.1 & \\
\hline 12 & \\
\hline 6.1 & \\
\hline 6.1 & \\
\hline 31 & \\
\hline-16.1 & \\
\hline 6.1 & \\
\hline-6.1 & \\
\hline 6.1 & \\
\hline-120 & \\
\hline-61 & \\
\hline-124 & \\
\hline 24 & \\
\hline 6.1 & \\
\hline 6.1 & \\
\hline 61 & \\
\hline 61 & \\
\hline 112 & \\
\hline-1240 & \\
\hline-131 & \\
\hline-12 & \\
\hline
\end{tabular}

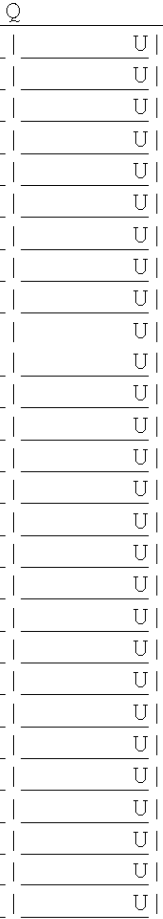


Lab Name: TestAmerica Laboratories, Ine.

Matrix: (soil/water) SOLID

Method: Sw846 8260B

Volatile Organics, GC/MS (8260B)

Sample WT/Vol: $4.97 / \mathrm{g}$

Work Order: MKX8L1CH

Dilution factor: 1

Moisture $8: 18$

Client Sample Id: INTRA-LAB QC
SDG Number:BEA025553

Lab Sample ID:F1G150469001

Date Received: 07/15/11

Date Extracted:07/24/11

Date Analyzed: 07/24/11

OC Batch: 1206129

\begin{tabular}{|c|c|c|c|}
\hline CAS NO. & $\begin{array}{l}\text { CONCENTRAT } \\
\text { (ug/L or ug }\end{array}$ & $\begin{array}{l}\text { RION UNITS: } \\
\mathrm{dg} / \mathrm{kg}) \mathrm{ug} / \mathrm{kg}\end{array}$ & Q \\
\hline $107-12-0$ & Propionitrile & 131 & $\mathrm{U}$ \\
\hline $123-91-1$ & 1,4-Dioxane & 490 & $\overline{\mathrm{U}} \mid$ \\
\hline $79-20-9$ & Methyl acetate & 6.1 & $\overline{\mathrm{U}} \mid$ \\
\hline $126-99-8$ & 2-Chloro-1,3-butadiene & 6.1 & $\overline{\mathrm{U}}$ \\
\hline $76-14-2$ & 1,2-Dichloro-1,1,2,2-tetrafl & 6.1 & $\overline{\mathrm{U}} \mid$ \\
\hline $96-18-4$ & 1,2,3-Trichloropropane & 6.1 & $\overline{\mathrm{U}}$ \\
\hline $95-63-6$ & 1,2,4-Trimethylbenzene & 6.1 & $\underline{\mathrm{U}}$ \\
\hline $74-95-3$ & Dibromomethane & 6.1 & $\overline{\mathrm{U}} \mid$ \\
\hline $1634-04-4$ & Methyl tert-butyl ether (MTB & 6.1 & $\overline{\mathrm{U}} \mid$ \\
\hline
\end{tabular}

SURROGATE RECOVERY

Toluene-d8

Dibromofluoromethane

1,2-Dich loroethane-d4

4-Bromofluorobenzene $\stackrel{\frac{9}{8}}{2}$

108

100

101

114
ACCEPTABLE LIMITS

$\left.\begin{array}{ll}(81 & -129 \\ (71 & -135 \\ (81 & -136 \\ (70 & -150\end{array}\right)$

EORM I 
Lab Name: TestAmerica Laboratories, Ine.

Matrix: (soil/water) SOLID

Method: Sw846 8260B

Volatile Organics, GC/MS (8260B)

Sample WT/Vol: $5 / \mathrm{g}$

Work Order: MK2L51AA

Dilution factor: 1

Moisture o: 15

Client Sample Id: BEA025553 TBD
SDG Number:BEA025553

Lab Sample ID:F1G200464 001

Date Received: 07/20/11

Date Extracted:07/24/11

Date Analyzed: 07/24/11

OC Batch: 1206129

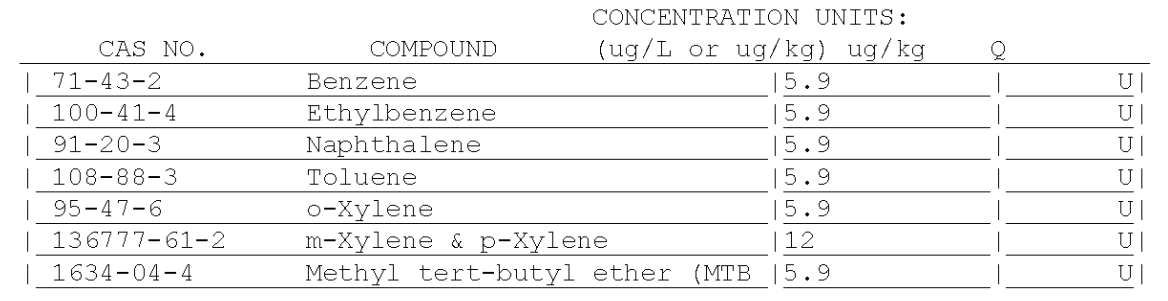

SURROGATE RECOVERY

Toluene-d8

Dibromofluoromethane

1,2-Dich loroethane-d4

4-Bromofluorobenzene

\section{$\stackrel{\circ}{8}$}

108

96

103

112
ACCEPTABLE LIMITS

$\left.\begin{array}{ll}(62 & -150 \\ (49 & -150\end{array}\right)$

FORM I 


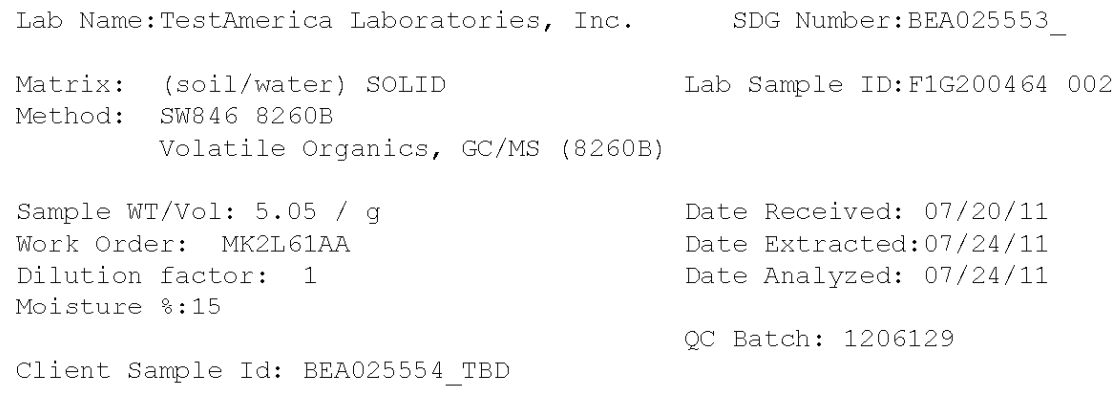

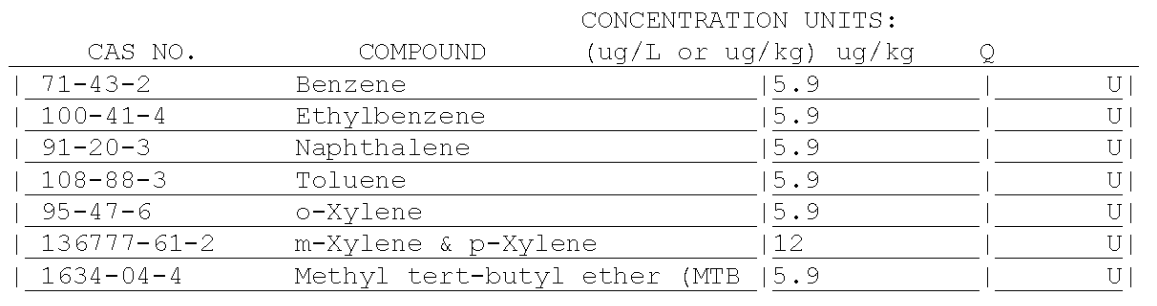

\section{SURROGATE RECOVERY}

Toluene-d8

Dibromof luoromethane

1,2-Dich loroethane-d4

4-Bromofluorobenzene

\section{$\stackrel{9}{b}$}

110

92

101

116 $\underline{\text { ACCEPTABLE LIMITS }}$

$\left.\begin{array}{ll}(62 & -150 \\ (49 & -150 \\ (69 & -142 \\ (44 & -150\end{array}\right)$

EORM I 
Lab Name: TestAmerica Laboratories, Ine.

Matrix: (soil/water) SOLID

Method: Sw846 8260B

Volatile Organics, GC/MS (8260E)

Sample WT/Vol: $5.01 / \mathrm{g}$

Work Order: MK2L $71 \mathrm{AA}$

Dilution factor: 1

Moisture $8: 18$

Client Sample Id: BEA025556_TBD
SDG Number:BEA025553_

Lab Sample ID:F1G200464 003

Date Received: 07/20/11

Date Extracted:07/24/11

Date Analyzed: 07/24/11

OC Batch: 1206129

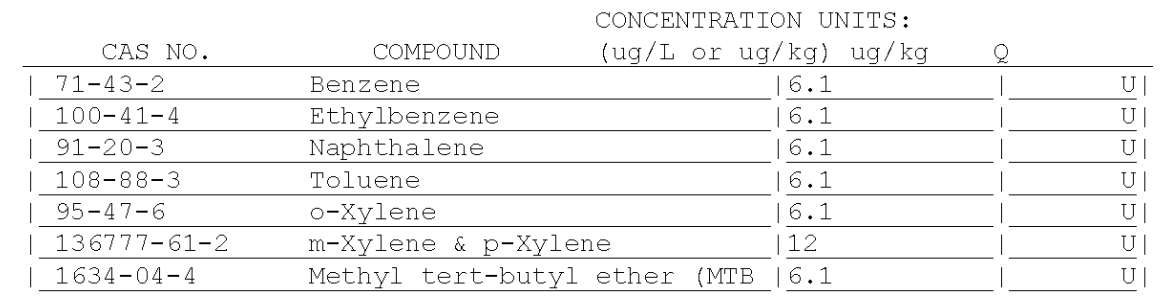

SURROGATE RECOVERY

Toluene-d8

Dibromofluoromethane

1,2-Dich loroethane-d4

4-Bromofluorobenzene $\stackrel{\circ}{8}$

109

94

104

113
ACCEPTABLE LIMITS

$\left.\begin{array}{ll}(62 & -150 \\ (49 & -150\end{array}\right)$

FORM I 


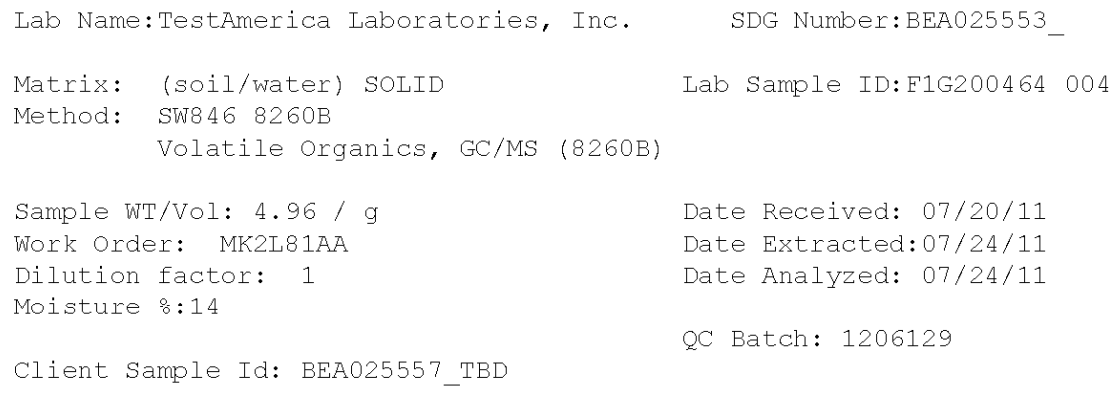

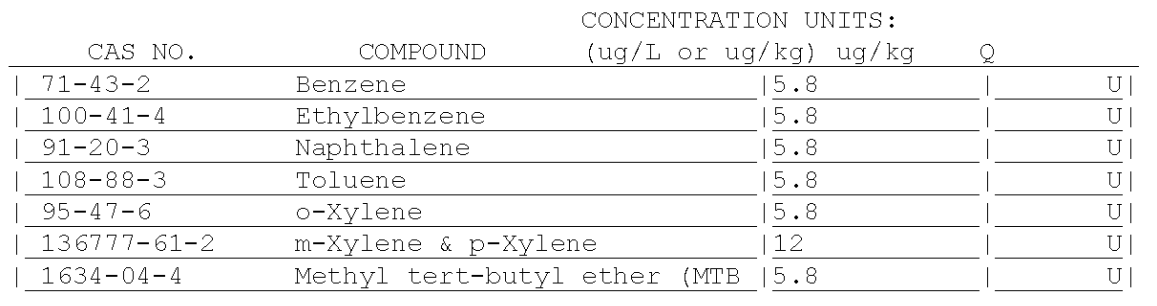

\section{SURROGATE RECOVERY}

Toluene-d8

Dibromofluoromethane

1,2-Dich loroethane-d4

4-Bromofluorobenzene

\begin{tabular}{lcl}
$\frac{\circ}{8}$ & ACCEPTABLE & LIMITS \\
\cline { 2 - 3 } 102 & $(62$ & $-150)$ \\
97 & $(49$ & $-150)$ \\
108 & $(69)$ & $-142)$ \\
116 & $(44$ & $-150)$
\end{tabular}

FORM I 


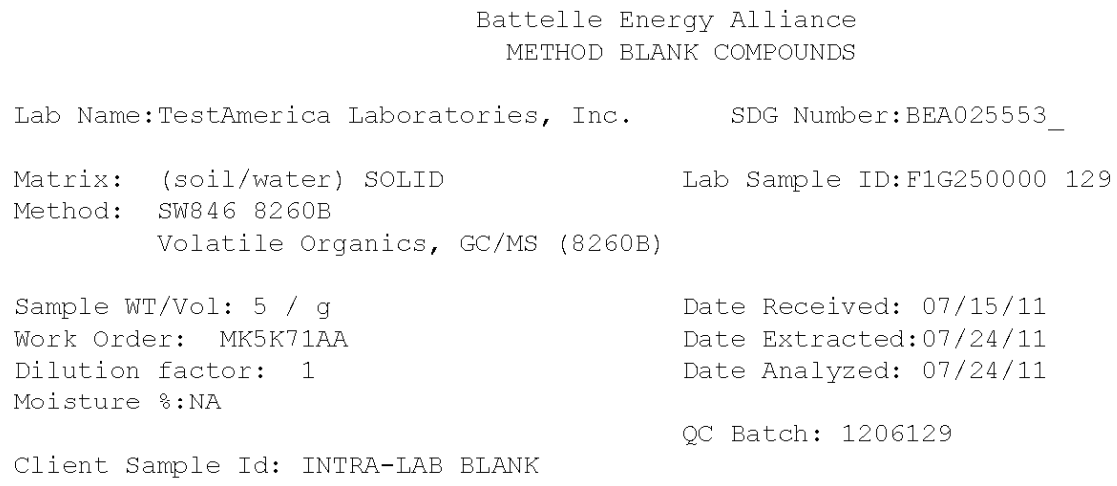

Client Sample Id: INTRA-LAB BLANK

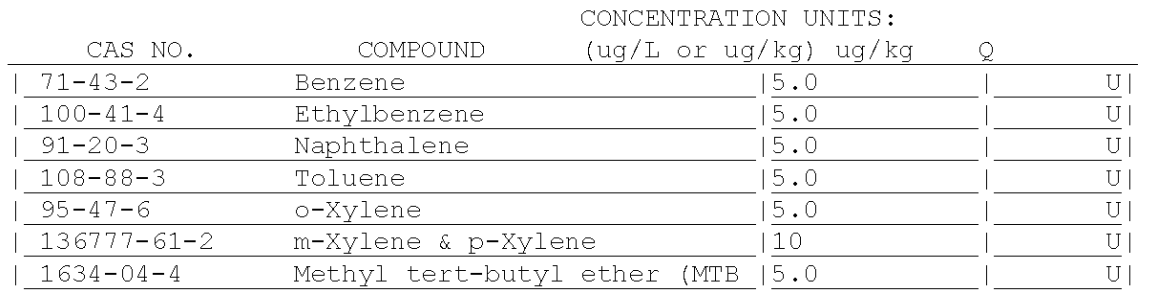

SURROGATE RECOVERY

Toluene-d8

Dibromofluoromethane

1,2-Dichloroethane-d4

4-Bromofluorobenzene

\section{$\stackrel{9}{b}$}

109

98

103

106 $\underline{\text { ACCEPTABLE LIMITS }}$

$\left.\begin{array}{ll}(62 & -150 \\ (49 & -150\end{array}\right)$

FORM I 


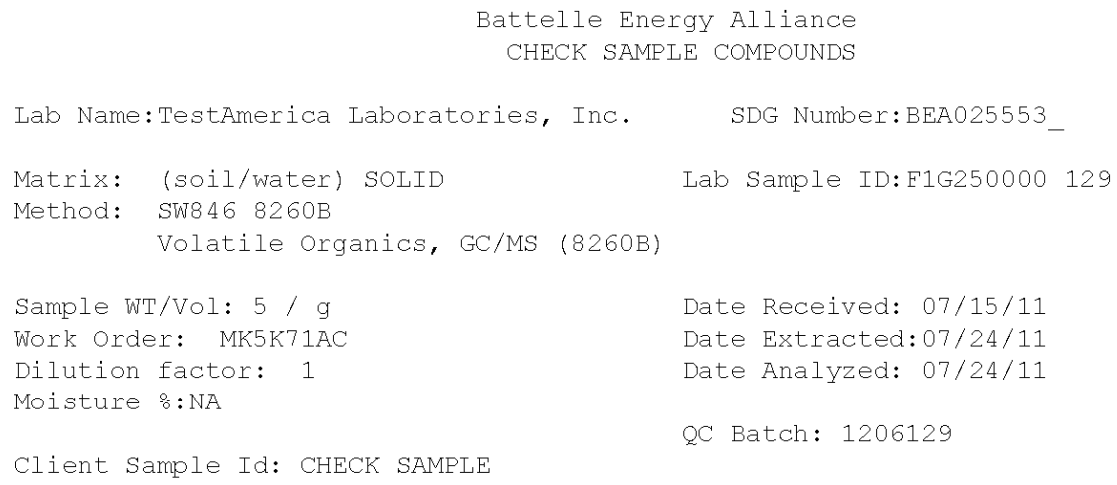

\begin{tabular}{|c|c|c|c|}
\hline CAS NO. & $\begin{array}{l}\text { CONCENTRAT } \\
\text { (ug/L or } u\end{array}$ & $\begin{array}{l}\text { ON UNITS: } \\
\mathrm{g} / \mathrm{kg}) \mathrm{ug} / \mathrm{kg}\end{array}$ & Q \\
\hline $71-43-2$ & Benzene & 48.5 & \\
\hline $100-41-4$ & Ethylbenzene & 46.5 & \\
\hline $91-20-3$ & Naphthalene & 150.1 & \\
\hline $108-88-3$ & Toluene & 46.3 & \\
\hline $95-47-6$ & o-Xylene & 150.9 & \\
\hline $136777-61-2$ & m-Xylene \& p-Xylene & 199.5 & \\
\hline $1634-04-4$ & Methyl tert-butyl ether (MTE & 151.6 & \\
\hline
\end{tabular}

SURROGATE RECOVERY

Toluene-d8

Dibromofluoromethane

1,2-Dich loroethane-d4

4-Bromofluorobenzene

\section{$\stackrel{\frac{\circ}{9}}{2}$}

108

101

102

109
ACCEPTABLE LIMITS

$\left.\begin{array}{ll}(85 & -119 \\ (85 & -115 \\ 81 & -117 \\ (85 & -116\end{array}\right)$

FORM I 


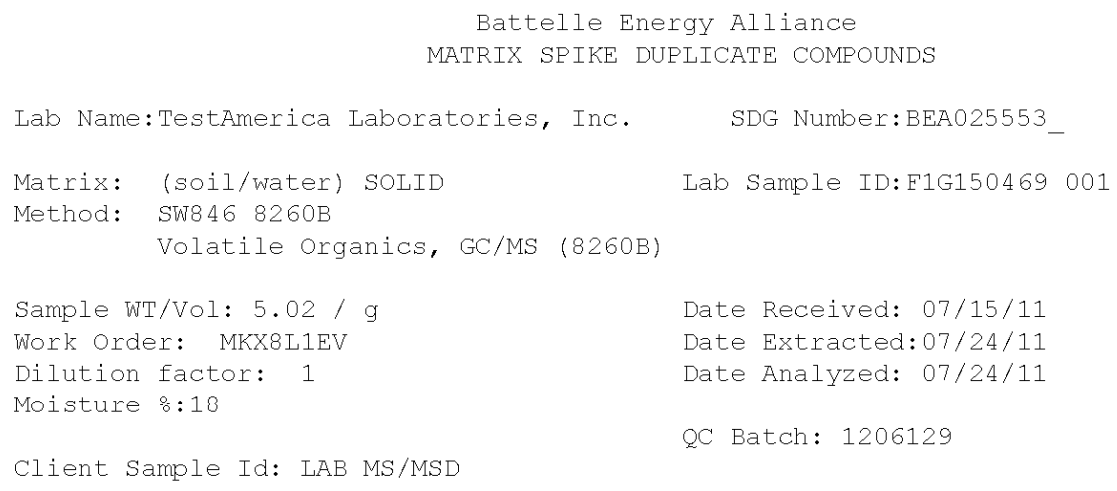

\begin{tabular}{|c|c|c|c|}
\hline CAS NO. & $\begin{array}{l}\text { CONCENTRATI } \\
\text { (ug/L or ug }\end{array}$ & $\begin{array}{l}\text { TION UNITS: } \\
\mathrm{lg} / \mathrm{kg}) \mathrm{ug} / \mathrm{kg}\end{array}$ & Q \\
\hline $71-43-2$ & Benzene & 157.7 & \\
\hline $100-41-4$ & Ethylbenzene & 56.6 & \\
\hline $91-20-3$ & Naphthalene & 52.3 & \\
\hline $108-88-3$ & Toluene & 58.1 & \\
\hline $95-47-6$ & o-xylene & 60.3 & \\
\hline $136777-61-2$ & m-Xylene \& p-Xylene & 119 & \\
\hline $1634-04-4$ & Methyl tert-butyl ether (MTE & 8.59 .3 & \\
\hline
\end{tabular}

SURROGATE RECOVERY

Toluene-d8

Dibromofluoromethane

1,2-Dichloroethane-d4

4-Bromofluorobenzene

\section{$\stackrel{9}{b}$}

111

100

98

113
ACCEPTABLE LIMITS

$\left.\begin{array}{ll}(62 & -150 \\ (49 & -150 \\ (69 & -142 \\ (44 & -150\end{array}\right)$

FORM I 


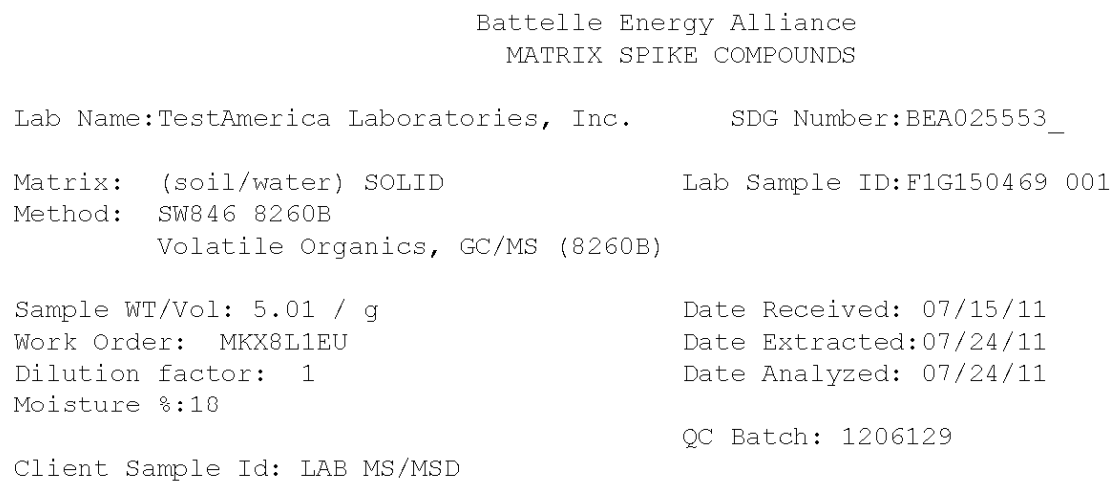

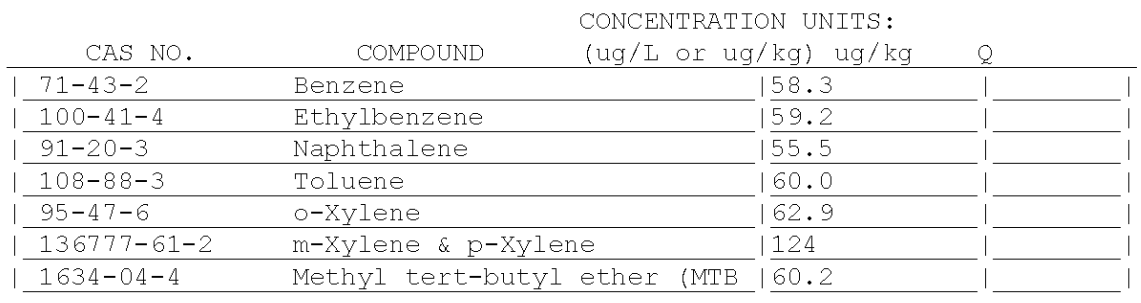

SURROGATE RECOVERY

Toluene-d8

Dibromofluoromethane

1,2-Dich loroethane-d4

4-Bromofluorobenzene

\section{$\stackrel{\frac{0}{8}}{2}$}

114

100

99

119
ACCEPTABLE LIMITS

$\left.\begin{array}{l}(62)-150 \\ (49) \\ (69-150) \\ (44-142\end{array}\right)$

F'ORM I 


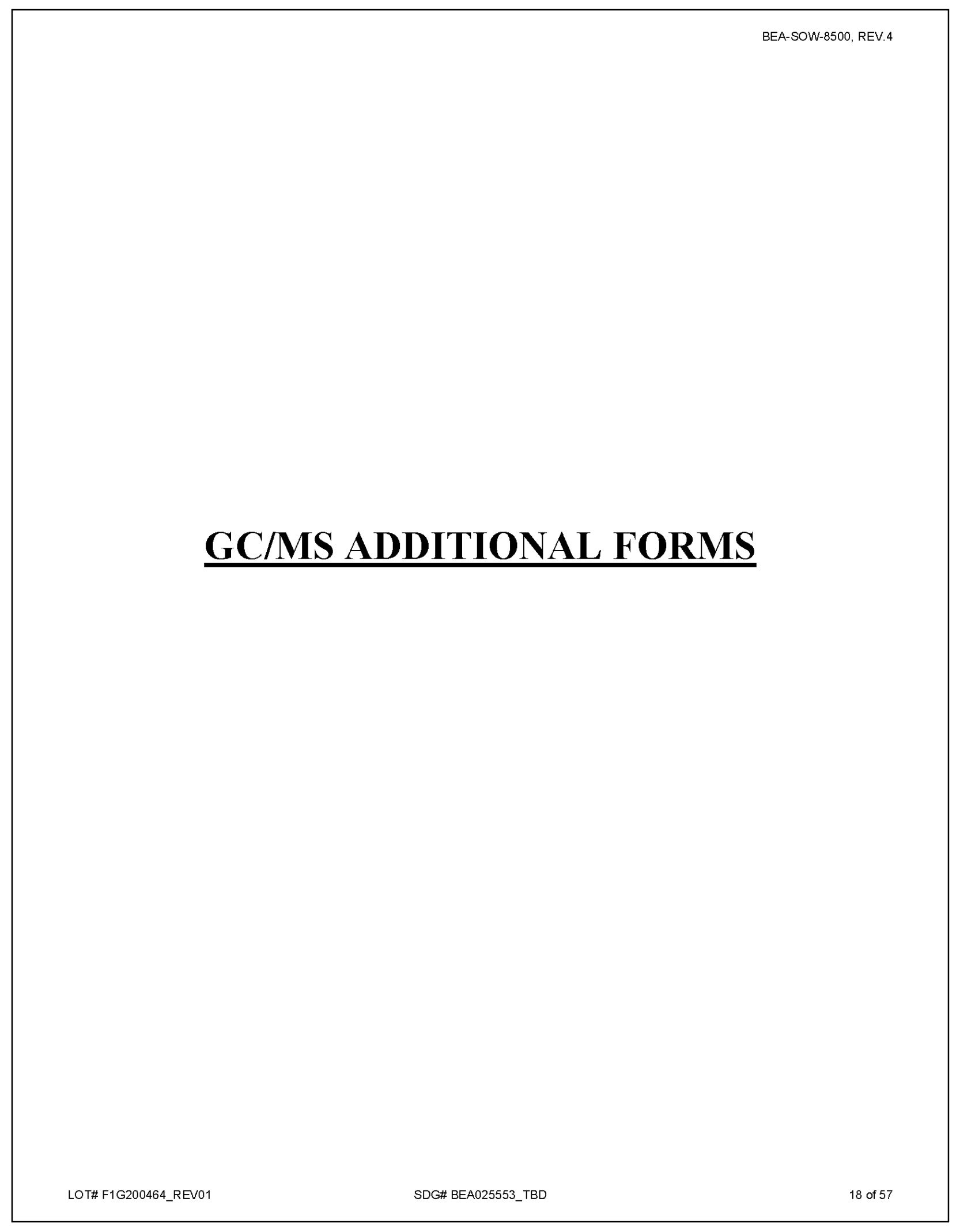


BEA-SOW-8500, REV.4

SW846 8260B SURROGATE RECOVERY

Lab Name: TestAmerica Laboratories, Inc.

Client: Battelle Energy Alliance

Lab code: TALSTL SDG No: BEA025553

Lot \#: F1G200464

Extraction: XXA15QK01

\begin{tabular}{|c|c|c|c|c|c|}
\hline \multirow{2}{*}{\multicolumn{6}{|c|}{$\begin{array}{cccccc}\text { CLIENT ID. } & \text { SRGO1 } & \text { SRG02 } & \text { SRG03 } & \text { SRG04 } & \text { TOT OUT } \\
|============================|=======|======|======|======|=====\mid\end{array}$}} \\
\hline & & & & & \\
\hline 01 INTRA-LAB QC & 108 & 100 & 101 & 114 & 00 \\
\hline $02 \mid \overline{\mathrm{EEA0} 25553 \mathrm{TBD}}$ & 108 & 96 & 103 & 112 & 00 \\
\hline $03 \mid \overline{\mathrm{BEA0} 25554 \mathrm{TBD}}$ & 110 & 92 & 101 & 116 & 00 \\
\hline $04 \mid \overline{\mathrm{BEA0} 025556 \mathrm{TBD}}$ & 109 & 94 & 104 & 113 & 00 \\
\hline $51 \overline{\mathrm{BEA} 025557 \mathrm{TBD}}$ & 102 & 97 & 108 & 116 & 00 \\
\hline 06।METHOD BLK. MK5K71AA & 109 & 98 & 103 & 106 & 00 \\
\hline $07 / \overline{\mathrm{LCS}} \mathrm{MK5}$ K71AC & 108 & 101 & 102 & 109 & 00 \\
\hline $8 \mid \mathrm{LAB} \mathrm{MS} / \mathrm{MSD} \mathrm{D}$ & 111 & 100 & 98 & 113 & 00 \\
\hline $91 \mathrm{LAB}$ MS/MSD $S$ & 114 & 100 & 99 & 119 & 00 \\
\hline
\end{tabular}

SURROGATES

SRG01 $=$ Toluene-d8

SRG02 = Dibromofluoromethane

SRG03 $=1,2-$ Dichloroethane-d4

SRG04

$=1,2-\mathrm{Dich}$ oroethane-d4
$=4$-Bromofluorobenzene
QC LIMITS

$(62-150)$

$(49-150)$

$(69-142)$

(44-150)

\# Column to be used to flag recovery values

* Values outside of required QC Limits

D System monitoring Compound diluted out

EORM II 
SW846 8260B MATRIX SPIKE/MATRIX SPIKE DUPLICATE RECOVERY

Lab Name: TestAmerica Laboratories, Inc.

Lab code: TALSTL

Matrix Spike ID: LAB MS/MSD

Lot \#: F1G150469
Client: Battelle Energy Alliance

SDG NO: BEA025553

Level: (low/med) LOW

WO \#: MKX8L1ET

BATCH: 1206129

\begin{tabular}{|c|c|c|c|c|c|c|c|}
\hline 1 & SPIKE & SAMPLE & MS & MS & \\
\hline | & ADDED & CONCENT. & CONCENT. & 8 & \multicolumn{3}{|l|}{ LIMITS } \\
\hline I COMPOUND & $(u g / k g)$ & $(\mathrm{ug} / \mathrm{kg})$ & $(\mathrm{ug} / \mathrm{kg})$ & $\mathrm{REC}$ & $\mathrm{REC}$ & & QUAL \\
\hline $\mid==============$ & $=\mid=======$ & $\mid=======$ & $========$ & $=====$ & $======$ & $===1$ & \\
\hline Ethylbenzene & 61.1 & $\underline{N D}$ & 59.2 & 97 & $55-$ & $141 \mid$ & \\
\hline Methyl tert-butyl ether & 61.1 & $\mathrm{ND}$ & 60.2 & 99 & $46-$ & 1501 & \\
\hline Naphthalene & 61.1 & $\mathrm{ND}$ & 55.5 & 91 & $24-$ & 1501 & \\
\hline Benzene & 61.1 & $\mathrm{ND}$ & 58.3 & 95 & $81-$ & $123 \mid$ & \\
\hline Toluene & 61.1 & $\mathrm{ND}$ & 60.0 & 98 & $62-$ & 1481 & \\
\hline m-Xylene \& p-Xylene & 122 & $\mathrm{ND}$ & 124 & 101 & $53-$ & 1401 & \\
\hline o-Xylene & 61.1 & $\mathrm{ND}$ & 62.9 & 103 & $52-$ & 1431 & \\
\hline
\end{tabular}

NOTEMS

Results and reporting limits have been adjusted for dry weight.

\# Column to be used to flag recovery and RPD values with an asterisk

* Values outside of oC limits

RPD: $\quad 0$ out of $\quad 0$ outside limits

Spike Recovery: $\quad 0 \overline{\text { out of } \quad-7}$ outside limits

COMMENTS :

FORM III 
SW846 8260B MATRIX SPIKE/MATRIX SPIKE DUPLICATE RECOVERY

Lab Name: TestAmerica Laboratories, Inc.

Lab code: TALSTL

Matrix Spike ID: LAB MS/MSD

Lot \#: F1G150469
Client: Battelle Energy Alliance

SDG NO: BEA025553

Level: (low/med) LOW

WO \#: MKX8L1EV

BATCH: 1206129

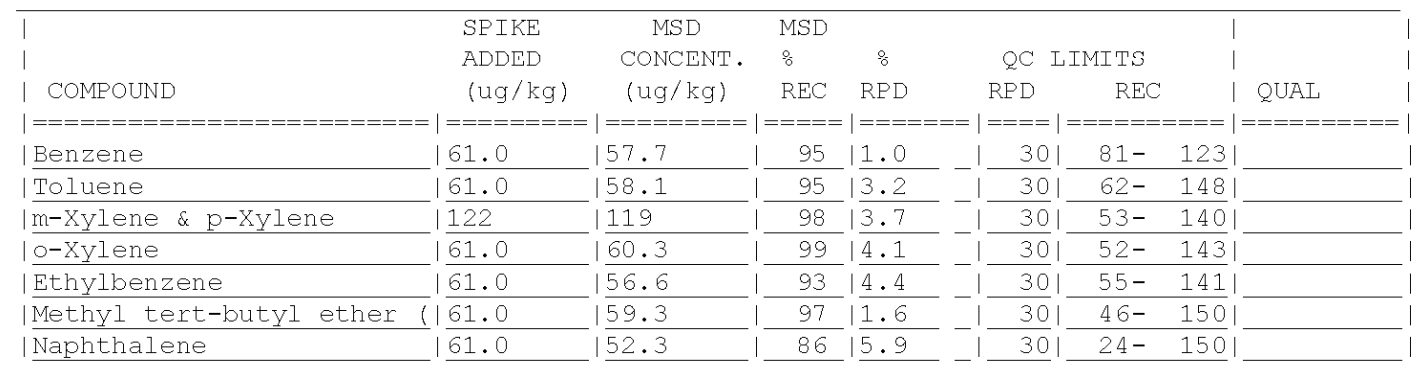

NOTEMS

Results and reporting limits have been adjusted for dry weight.

\# column to be used to flag recovery and RPD values with an asterisk

* Values outside of oC limits

RPD: $\quad 0$ out of $\quad \frac{7}{0}$ outside limits

Spike Recovery: _ $\quad 0 \overline{\text { out of } \quad 7}$ outside limits

COMMENTS:

FORM III 
SW846 8260B CHECK SAMPLE RECOVERY

Lab Name: TestAmerica Laboratories, Inc.

Lab Code: TALSTL

Lot \#: F1G250000
Client: Battelle Energy Alliance

SDG NO: BEA025553

WO \# : MK5 K71AC

BATCH : 1206129

\begin{tabular}{|c|c|c|c|c|c|}
\hline | & SPIKE & SAMPLE & & $Q C$ & I \\
\hline | & ADDED & CONCENT. & $\frac{\circ}{8}$ & LIMITS & | \\
\hline | COMPOUND & $(u g / k g)$ & $(\mathrm{ug} / \mathrm{kg})$ & $\mathrm{REC}$ & $\mathrm{REC}$ & IQUAL \\
\hline 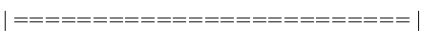 & $=======$ & $======$ & $====$ & $=======$ & $========$ \\
\hline Benzene & 50.0 & 48.5 & 97 & $85-$ & \\
\hline Toluene & 50.0 & 46.3 & 93 & $85-$ & \\
\hline m-XYlene \& p-XYlene & 100 & 99.5 & 99 & $85-$ & \\
\hline o-Xylene & 50.0 & 50.9 & 102 & $85-$ & \\
\hline Ethylbenzene & 50.0 & 46.5 & 93 & $85-$ & \\
\hline Methyl tert-butyl ether (। & 50.0 & 51.6 & 103 & $82-$ & \\
\hline Naphthalene & 50.0 & 50.1 & 100 & $75-$ & \\
\hline
\end{tabular}

NOTEMS

* Values outside of QC limits

Spike Recovery: _ـ out of $\quad$ _ $\quad 7$ outside limits

COMMENTS:

FORM III 
SW846 8260B METHOD BLANK SUMMARY

Lab Name: TestAmerica Laboratories, Inc.

Lab code: TALSTL

Lab File ID: FBLK6176

Date Analyzed: 07/24/11

Matrix: SOLID

GC Column: RTX-502.2 ID: .25

Instrument ID: MSF
BLANK WORKORDER NO.

|

| MK5 K71AA

|

SDG Number:BEA025553

Lot Number: F1G200464

Time Analyzed: 19:37

Date Extracted:07/24/11

Extraction Method: 5030B

Level: (low/med) LoW

THIS METHOD BLANK APPLIES TO THE FOLLONING SAMPLES, LCS, LCSD, MS, MSD:

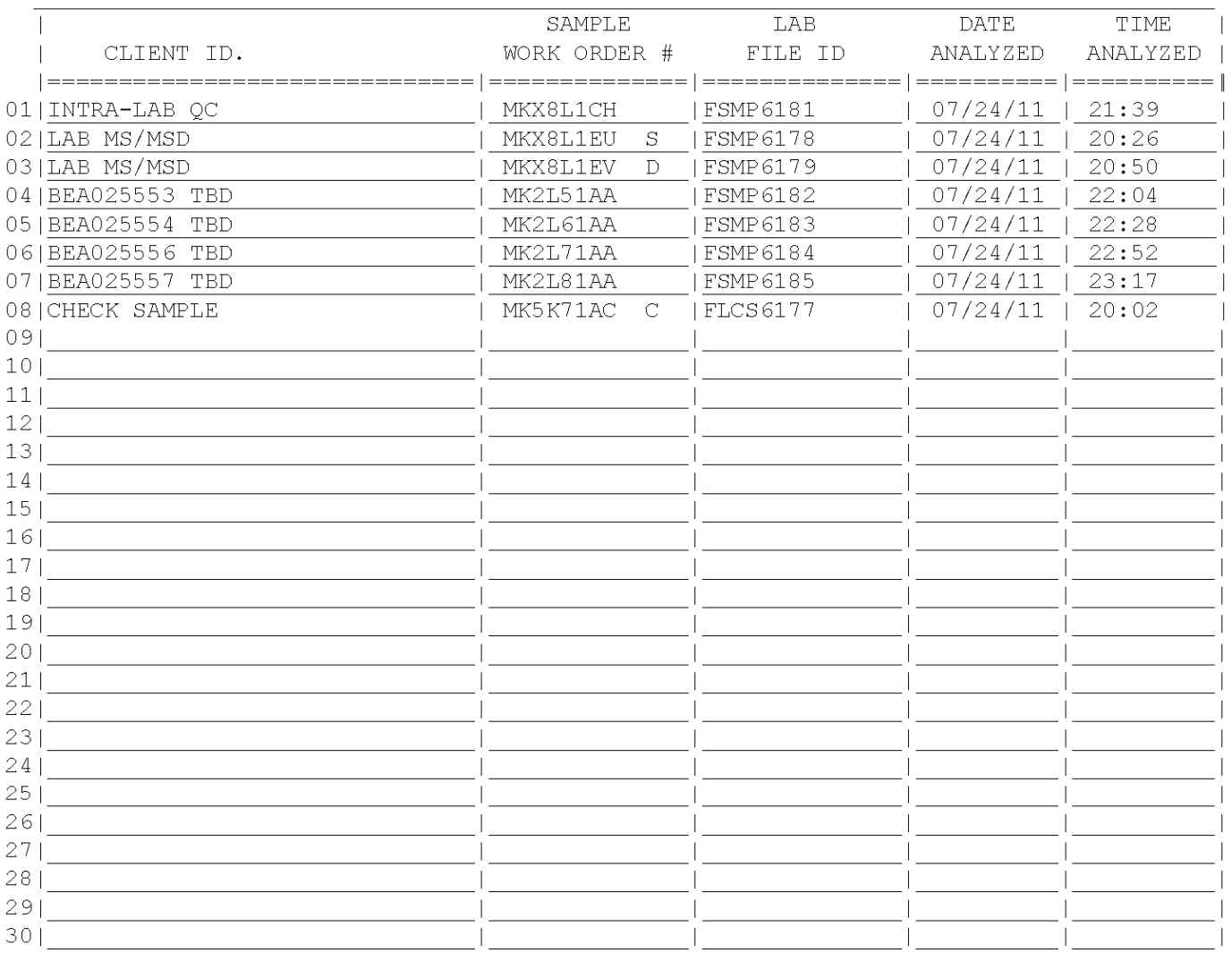

COMMENTS: 
EORM 5

VOLATILE ORGANIC INSTRUMENT PEREORMANCE CHECK BROMOELUOROBENZENE (BEB)

Lab Name: TESTAMERICA ST. LOUIS Contract: 9661

Lab Code: Case No.: SAS No.: SDG No.: F1G200464

Lab File ID: FBEB5574

BEB Injection Date: 06/12/11

Instrument ID: MSE

BEB Injection Time: 1654

GC Column: RTX-VMS ID: 0.25 (mm)

Heated Purge: (Y/N) N

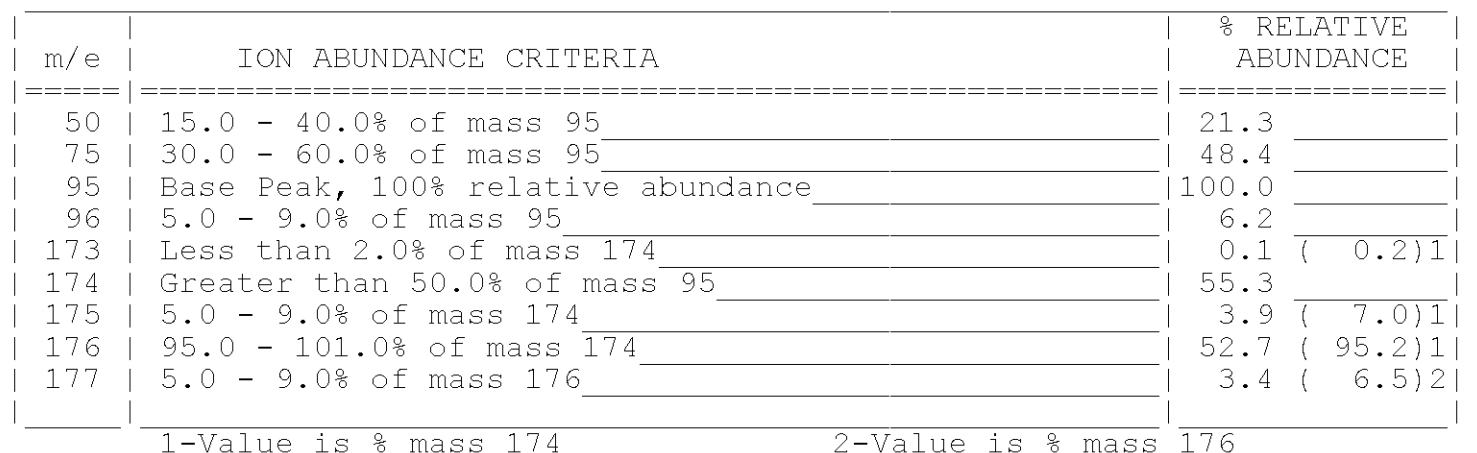

THIS CHECK APPLIES TO THE FOLLONING SAMPLES, MS, MSD, BLANKS, AND STANDARDS:

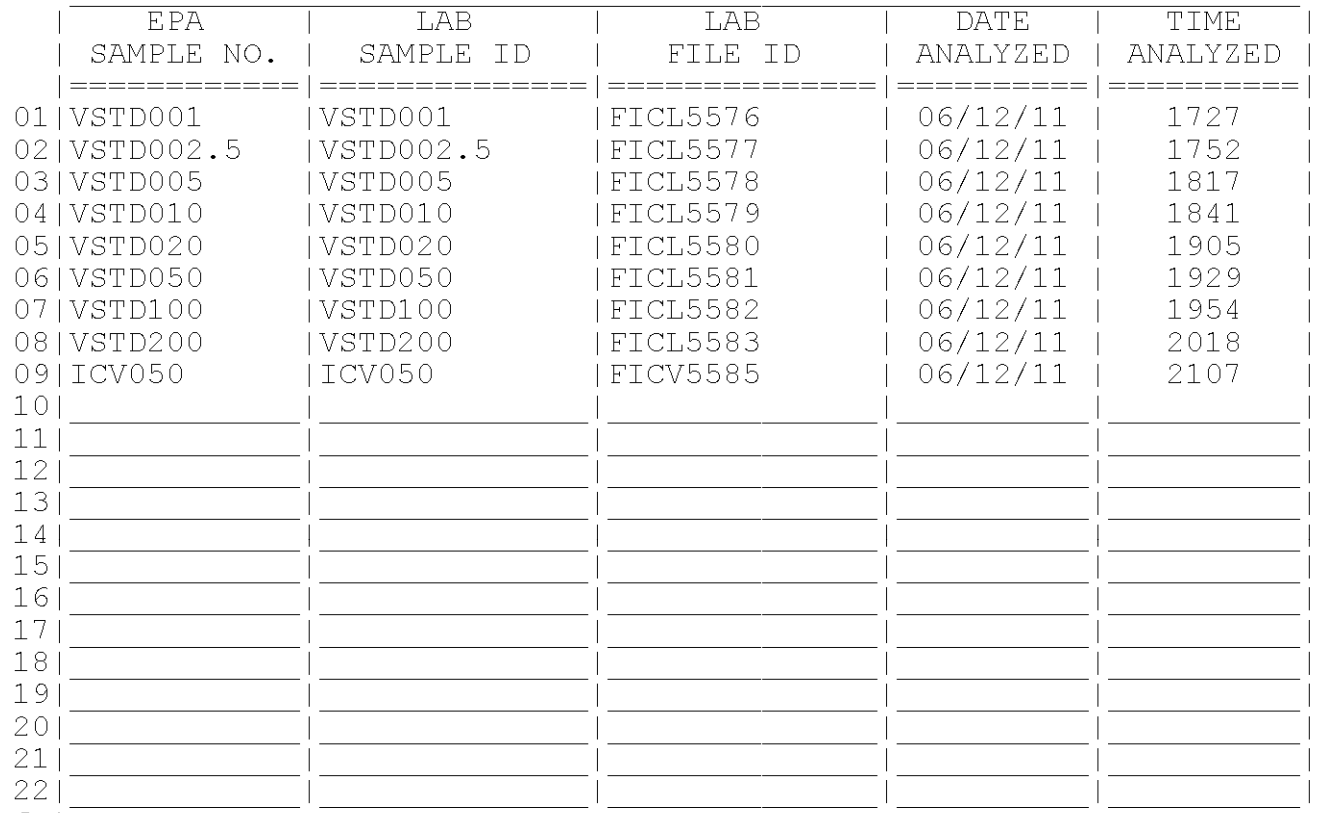

page 1 of 1

EORM V VOA 
EORM 5

VOLATILE ORGANIC INSTRUMENT PEREORMANCE CHECK BROMOELUOROBENZENE (BEB)

Lab Name: TESTAMERICA ST. LOUIS Contract: 9661

Lab Code: Case No.: SAS No.: SDG No.: F1G200464

Lab File ID: FBEB6159

BEB Injection Date: 07/24/11

Instrument ID: MSE

BEB Injection Time: 1240

GC Column: RTX-VMS ID: 0.25 (mm)

Heated Purge: (Y/N) N

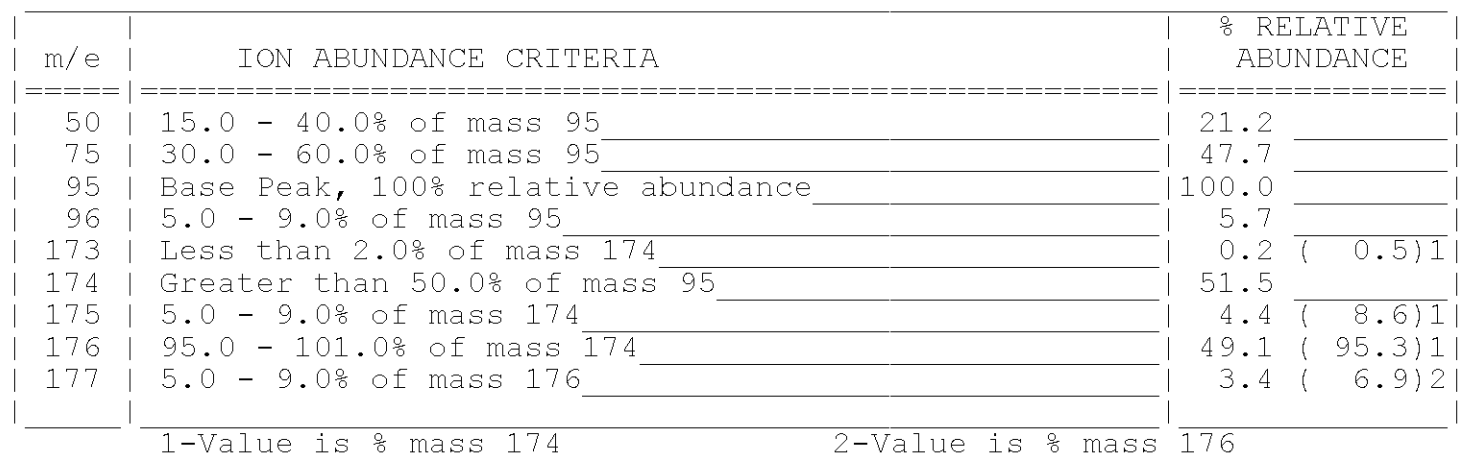

THIS CHECK APPLIES TO THE FOLLOWING SAMPLES, MS, MSD, BLANKS, AND STANDARDS:

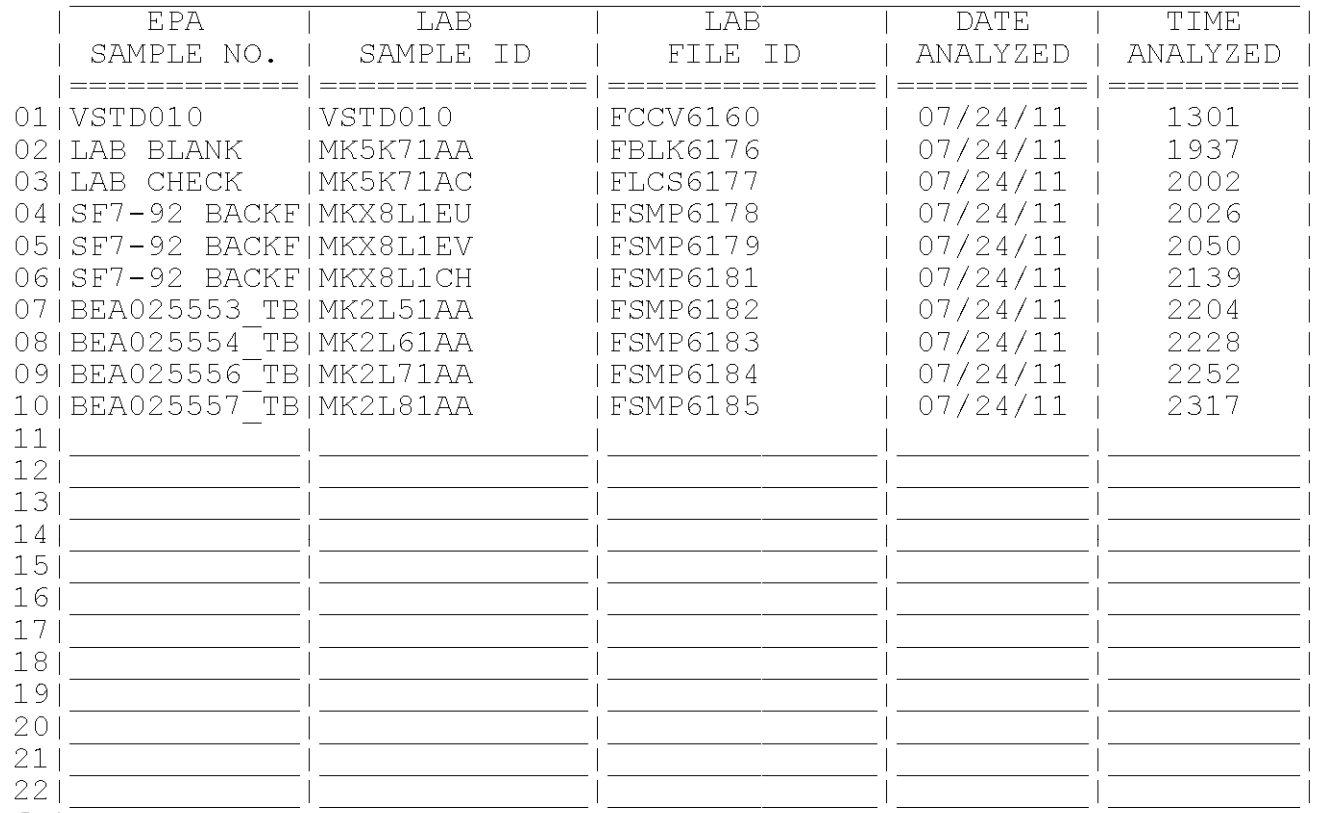

page 1 of 1

EORM V VOA 
EORM 6

VOLATILE INITIAL CALIBRATION DATA

Lab Name: TESTAMERICA ST. LOUIS

Lab Code:

Case No.:

Instrument ID: MSE

Column: RTX-VMS ID: 0.25 (mm)
Contract: 9661

SAS NO.:

SDG No.: F1G200464

Calibration Date(s) : 06/12/11 06/12/11

Calibration Time(s) : 1727

2018

LAB FILE ID: RF1: FICL5576 RF2.5: FICL5577 RF5: FICL5578

RF10: FICL5579 RF20: FICL5580 RF50: FICL5581

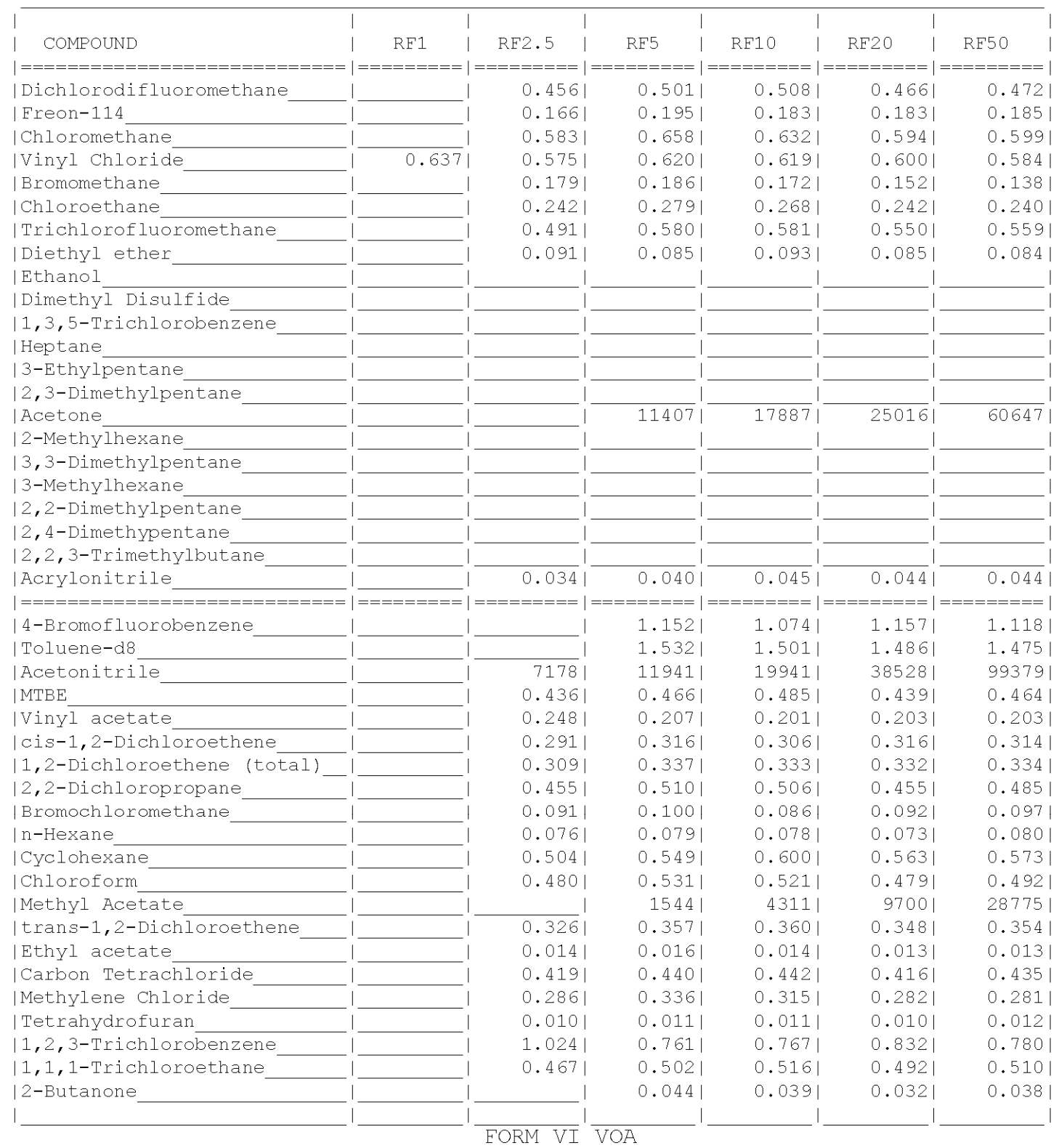


BEA-SOW-8500, REV.4

EORM 6

VOLATILE INITIAL CALIBRATION DATA

Lab Name: TESTAMERICA ST. LOUIS

Lab Code:

Instrument ID: MSE

Column: RTX-VMS ID: 0.25 (mm)
Contract: 9661

SAS NO.:

SDG No.: F1G200464

Calibration Date(s) : 06/12/11 06/12/11

Calibration Time(s) : 1727

2018

LAB FILE ID: RF1: FICL5576 RF2.5: FICL5577 RF5: FICL5578

RF10: EICL5579 RF20: FICL5580 RF50: FICL5581

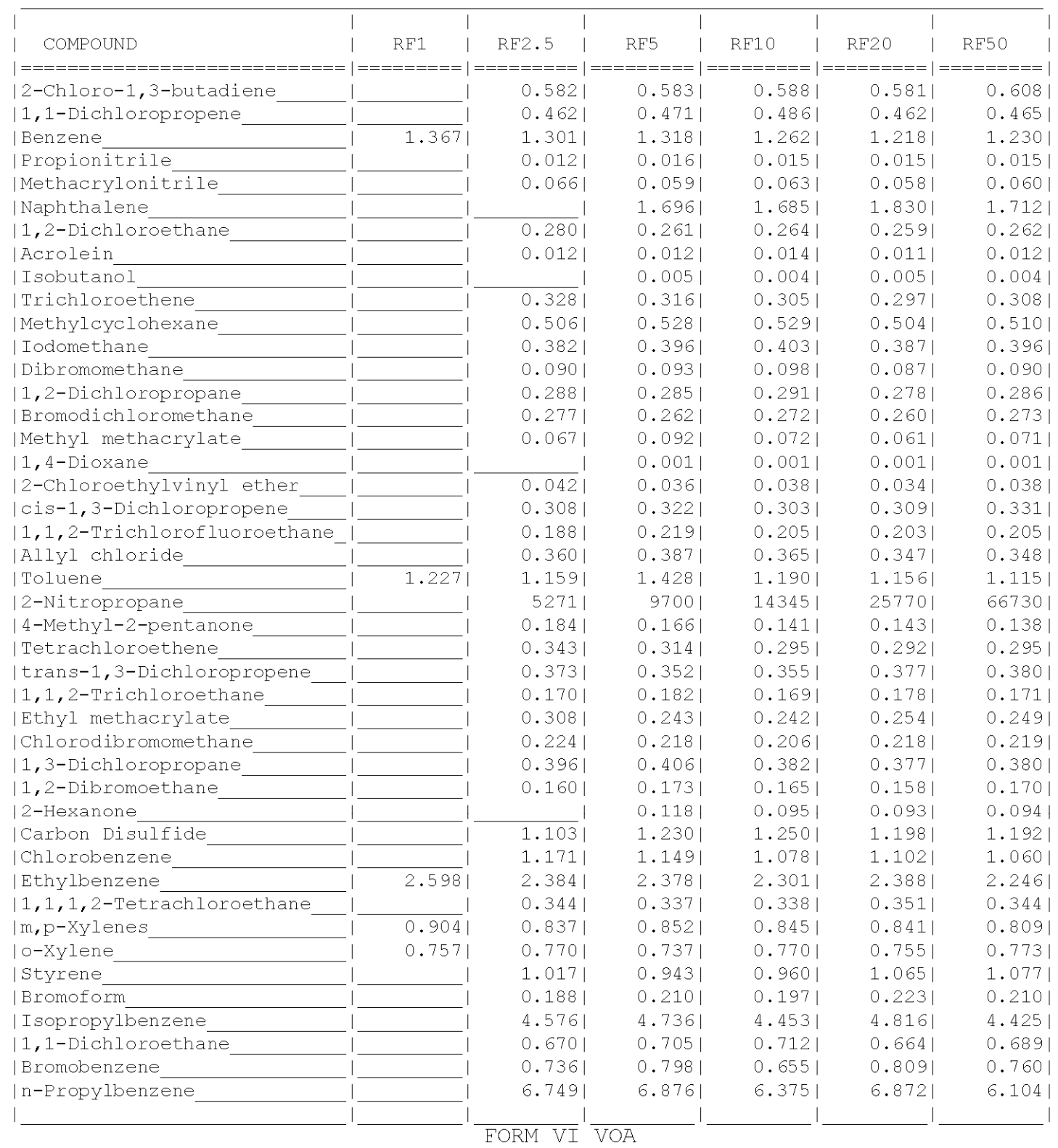


BEA-SOW-8500, REV.4

EORM 6

VOLATILE INITIAL CALIBRATION DATA

Lab Name: TESTAMERICA ST. LOUIS

Lab Code:

Case No.:

Instrument ID: MSE

Column: RTX-VMS ID: $0.25 \quad(\mathrm{~mm})$
Contract: 9661

SAS NO.:

SDG No.: F1G200464

Calibration Date(s): 06/12/11 06/12/11

Calibration Time(s): $1727 \quad 2018$

LAB FILE ID: RF1: FICL5576 RF2.5: FICL5577 RF5: FICL5578

RF10: FICL5579 RF20: FICL5580 RF50: FICL5581

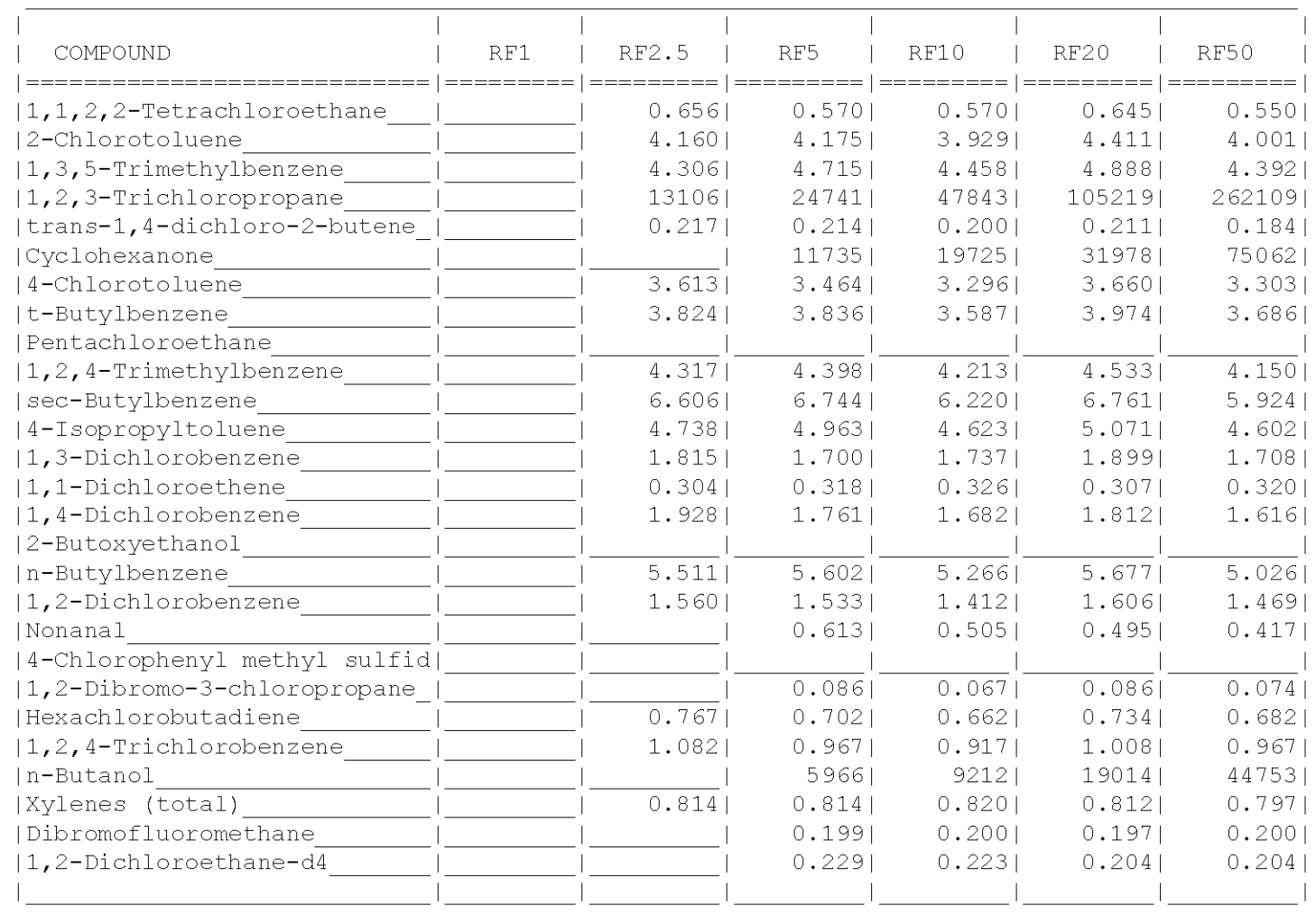

FORM VI VOA 
EORM 6

VOLATILE INITIAL CALIBRATION DATA

Lab Name: TESTAMERICA ST. LOUIS

Lab Code:

Case No.:

Instrument ID: MSE

Column: RTX-VMS ID: 0.25 (mm)
Contract: 9661

SAS NO.:

SDG No.: F1G200464

Calibration Date(s) : 06/12/11 06/12/11

Calibration Time(s) : 1727

2018

LAB FILE ID: RF100: FICL5582 RF200: FICL5583

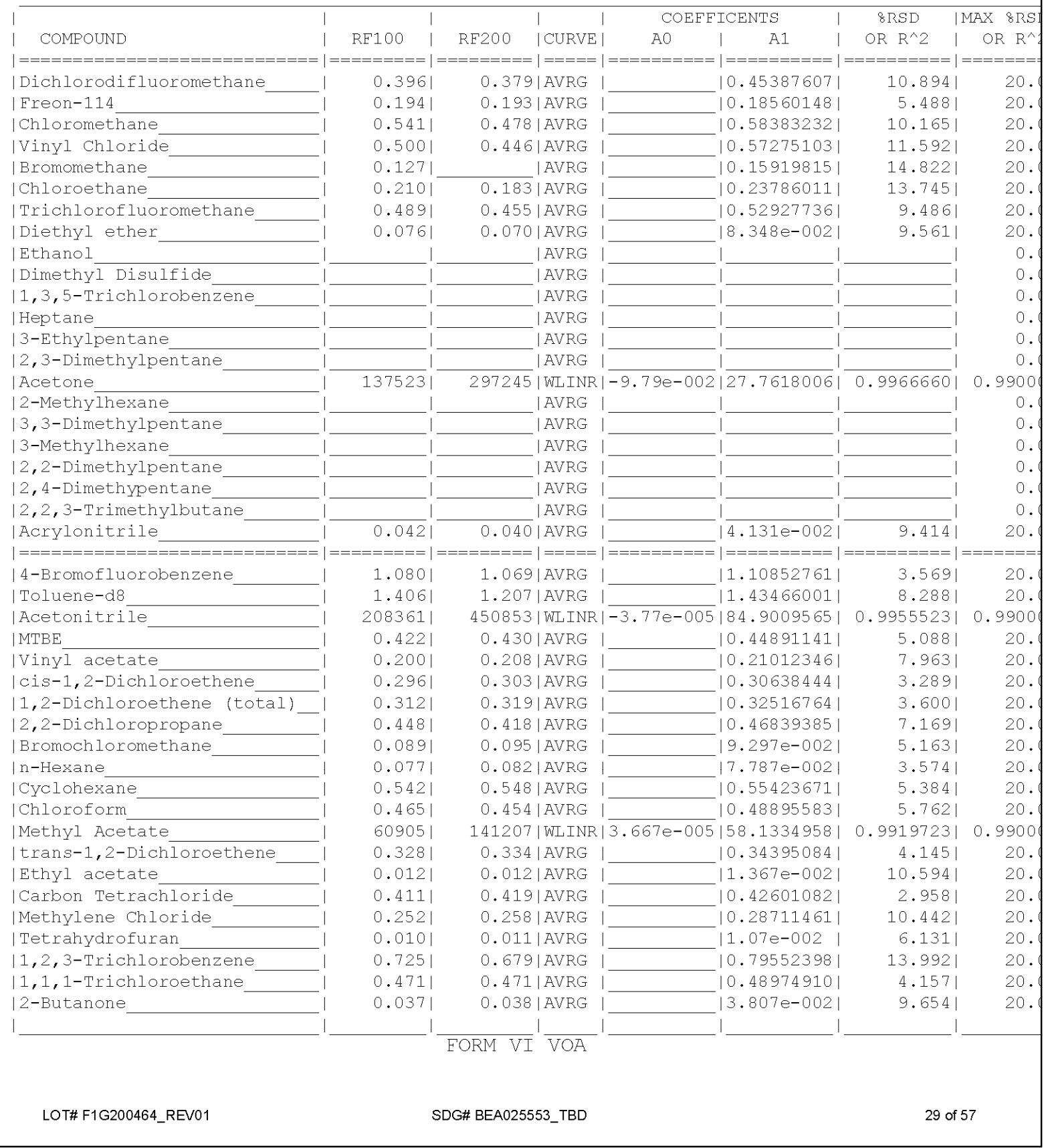


EORM 6

VOLATILE INITIAL CALIBRATION DATA

Lab Name: TESTAMERICA ST. LOUIS

Lab Code:

Case No.:

Instrument ID: MSE

Column: RTX-VMS ID: 0.25 (mm)
Contract: 9661

SAS NO.:

SDG No.: F1G200464

Calibration Date(s) : 06/12/11 06/12/11

Calibration Time(s) : 1727

2018

LAB FILE ID: RF100: FICL5582 RF200: FICL5583

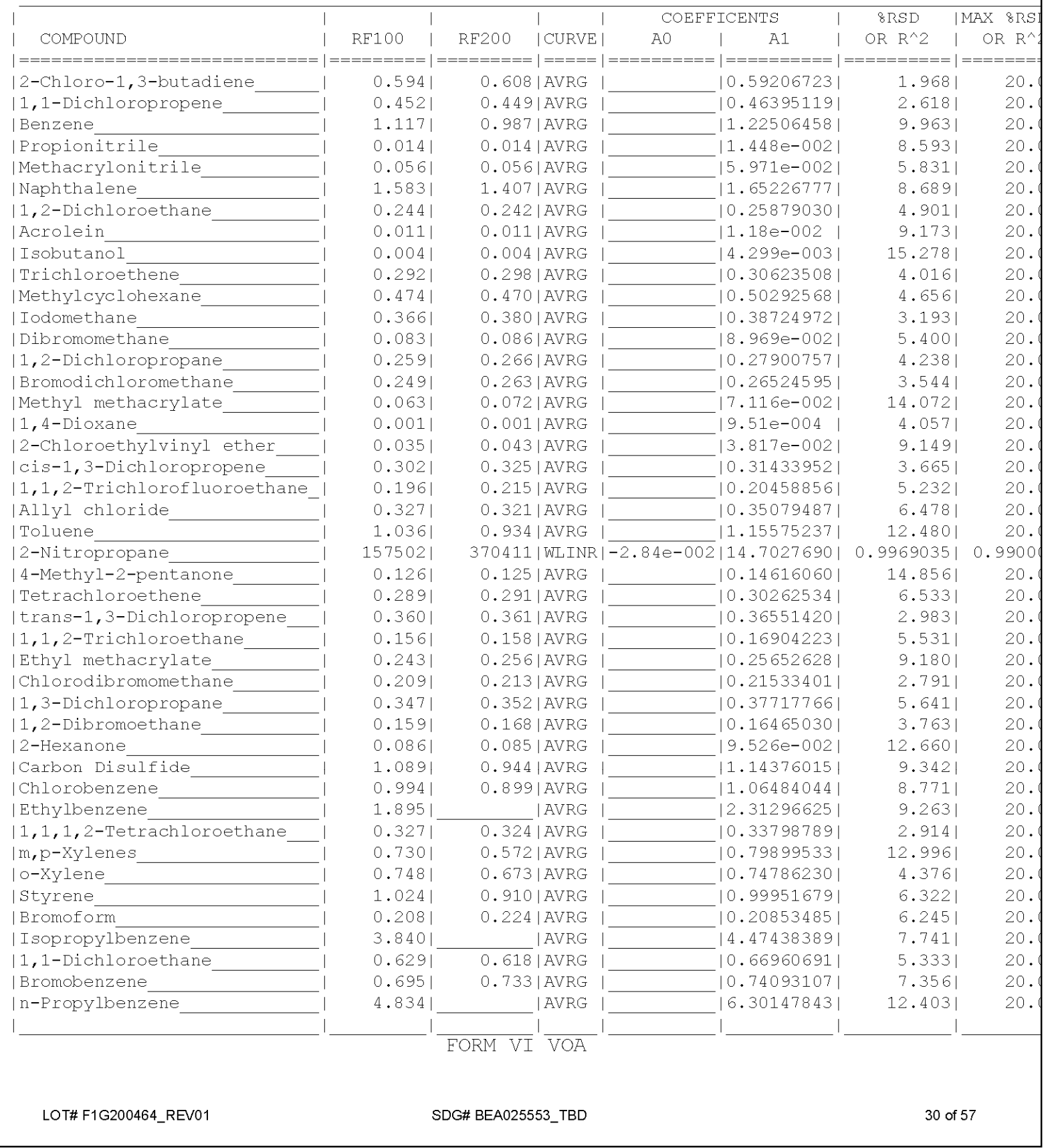


EORM 6

VOLATILE INITIAL CALIBRATION DATA

Lab Name: TESTAMERICA ST. LOUIS

Lab Code:

Case No.:

Instrument ID: MSE

Column: RTX-VMS ID: 0.25 (mm)
Contract: 9661

SAS NO.:

SDG No.: F1G200464

Calibration Date(s): 06/12/11 06/12/11

Calibration Time(s): $1727 \quad 2018$

LAB FILE ID: RF100: FICL5582 RF200: FICL5583

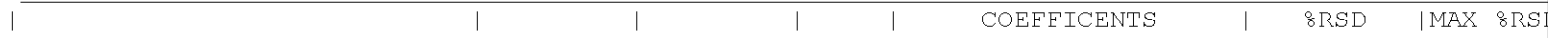

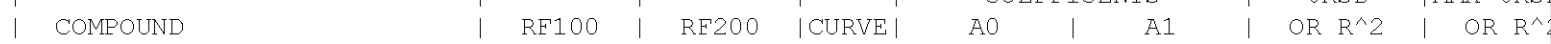

| $===================$

$1,1,2,2-$ Tetrachloroethane

12-Chlorotoluene

1,3,5-Trimethylbenzene

1,2,3-Trichloropropane

| trans-1,4-dichloro-2-butene

| Cyclohexanone

| 4-Chlorotoluene

t-Butylbenzene

| Pentachloroethane

1,2,4-Trimethylbenzene

I sec-Butylbenzene

|4-Isopropyltoluene

1,3-Dichlorobenzene

1,1-Dichloroethene

1,4-Dichlorobenzene

| 2-Butoxyethanol

n-Butylbenzene

| 1,2-Dichlorobenzene

| Nonana 1

14-Chlorophenyl methyl sulfid

|1,2-Dibromo-3-chloropropane

| Hexach lorobutadiene

1,2,4-Trichlorobenzene

| n-Butanol

XYlenes (total)

| Dibromofluoromethane

1,2-Dichloroethane-d4

| $=======1======\mid====$

$0.491|\quad 0.492|$ AVRG |

3.547 2.940|AVRG

$3.706\left|\_\right|$AVRG

4468021

0.168

$175268 \mid$

$2.967 \mid$

3.3281

$973557 \mid$ LINR

0.168 |AVRG |

400152 | WLINR |

2.424|AVRG |

$2.600 \mid$ AVRG

$3.614|+|$ AVRG |

4.7701

$3.794 \mid$

$1.621 \mid$

0.298

AVRG

| AVRG

| AVRG

$1.564 \mid$

$0.309 \mid$ AVRG

1.455|AVRG |AVRG

4.030

1.377

| AVRG

0.4221

0.071

$0.632 \mid$

$0.927 \mid$

$88016 \mid$

0.7361

$0.198 \mid$

0.195

\begin{tabular}{|c|c|c|c|}
\hline $\mathrm{AO}$ & A1 & OR $R^{\wedge} 2$ & $\mathrm{OR} \mathrm{R} \mathrm{R}^{\wedge}$ \\
\hline$====$ & $|=========|$ & $==========\mid$ & $=====$ \\
\hline & $|0.56784225|$ & $11.557 \mid$ & 20 . \\
\hline & $|3.88045809|$ & $12.711 \mid$ & 20 . \\
\hline & $|4.41065233|$ & 9.2361 & 20 . \\
\hline $9.59 e-002$ & $|2.34290616|$ & 0.9915708 & 0.9900 \\
\hline & $|0.19443018|$ & $10.924 \mid$ & 20 . \\
\hline $8.41 e-005$ & $|56.0066851|$ & $0.9915181 \mid$ & 0.9900 \\
\hline & $|3.24689851|$ & $13.262 \mid$ & 20 . \\
\hline & $|3.54775263|$ & $13.164 \mid$ & 20 . \\
\hline & & & 0 . \\
\hline & $|4.20445479|$ & 7.5911 & 20 . \\
\hline & $|6.17082011|$ & $12.324 \mid$ & 20 . \\
\hline & $|4.63176958|$ & 9.7341 & 20 . \\
\hline & $|1.71574756|$ & 7.0491 & 20 . \\
\hline & $|0.31166108|$ & 3.2021 & 20 \\
\hline & $|1.68816639|$ & 9.4601 & 20 . \\
\hline & & & 0 . \\
\hline & $|\overline{5.18509549}|$ & $11.852 \mid$ & 20 . \\
\hline & $|1.46448447|$ & 7.5511 & 20 . \\
\hline & $|0.48382417|$ & $15.086 \mid$ & 20 . \\
\hline & & & 0 . \\
\hline & $|7.58 e-002|$ & 10.6391 & 20 . \\
\hline & $|0.68255238|$ & 8.4951 & 20 . \\
\hline & $|0.96340815|$ & 7.0461 & 20 . \\
\hline$-1.49 e-004$ & $|382.997972|$ & $0.9917493 \mid$ & 0.9900 \\
\hline & $|0.77145661|$ & $10.181 \mid$ & 20 . \\
\hline & $|0.19905530|$ & 0.6721 & 20 \\
\hline & $|0.20807750|$ & 7.0461 & 20 . \\
\hline & & & \\
\hline
\end{tabular}

FORM VI VOA 
Data Eile: FICV5585.D

Report Date: 16-Jun-2011 17:50

TestAmerica St. Louis

CONTINUING CALIBRATION COMPOUNDS

Instrument ID: MSE.i

Lab File ID: FICV5585. D

Injection Date: 12-JUN-2011 21:07

Analysis Type: WATER

Init. Cal. Date(s): 12-JUN-2011 12-JUN-2011

Lab Sample ID: ICV050

Init. Cal. Times: 17:27 20:18

Quant Type: ISTD

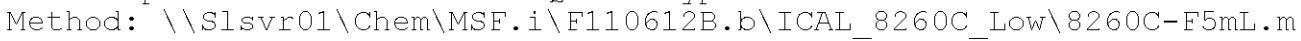

\begin{tabular}{|c|c|c|c|c|c|c|c|c|c|}
\hline | & & I__ & I & । & CCAL & | MIN | & । & MAX & | \\
\hline | & COMPOUND & | RRF & / AMOUNT | & RF 50 & RRF50 & | RRF | & / $\%$ DRIFT $\mid \frac{\circ}{5}$ & / $\frac{\mathrm{O} D R I F T}{}$ & | CURVE TYPE| \\
\hline 11 & 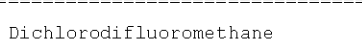 & । & 0.453881 & 0.425061 & 0.42506 & $0.000 \mid$ & 6.349711 & 20.000001 & Averaged | \\
\hline & Freon-114 & । & 0.185601 & 0.189851 & 0.18985 & 10.0001 & $-2.28944 \mid$ & 20.000001 & | Averaged | \\
\hline 13 & Chloromethane & । & 0.583831 & 0.560101 & 0.56010 & $10.100 \mid$ & 4.065231 & 20.000001 & | Averaged | \\
\hline & Vinyl Chloride & । & 0.572751 & $0.50114 \mid$ & 0.50114 & $10.000 \mid$ & 12.502811 & 20.000001 & | Averaged | \\
\hline & Bromomethane & । & 0.159201 & 0.130111 & 0.13011 & 10.0001 & $18.27129 \mid$ & 20.000001 & | Averaged | \\
\hline 16 & Chloroethane & । & 0.237861 & 0.201591 & 0.20159 & 10.0001 & 15.250311 & 20.000001 & | Averaged | \\
\hline 17 & Trichlorofluorome thane & । & $0.52928 \mid$ & 0.469051 & 0.46905 & 10.0001 & $11.37888 \mid$ & 20.000001 & | Averaged | \\
\hline & Diethyl ether & । & $0.08348 \mid$ & 0.069571 & 0.06957 & $10.000 \mid$ & $16.66821 \mid$ & 20.000001 & | Averaged | \\
\hline & 1,1-Dichloroethene & । & 0.311661 & 0.309741 & 0.30974 & $10.000 \mid$ & $0.61664 \mid$ & 20.000001 & | Averaged | \\
\hline 110 & 0 Carbon Disulfide & । & 1.143761 & 1.158151 & 1.15815 & 10.0001 & $-1.25835 \mid$ & 20.000001 & | Averaged | \\
\hline | 11 & 1 1,1,2-Trichlorofluoroethane & । & 0.204591 & 0.209661 & 0.20966 & 10.0001 & -2.480211 & 20.000001 & | Averaged | \\
\hline 112 & 2 Iodomethane & । & 0.387251 & 0.395881 & 0.39588 & $|0.000|$ & $-2.22945 \mid$ & 20.000001 & | Averaged | \\
\hline 113 & 3 Acrolein & । & 0.011801 & 0.011441 & 0.01144 & 10.0001 & 3.020261 & 20.000001 & | Averaged | \\
\hline 14 & 4 Allyl chloride & । & 0.350791 & 0.318121 & 0.31812 & 10.0001 & $9.31418 \mid$ & 20.000001 & | Averaged | \\
\hline 115 & 5 Methylene Chloride & । & 0.287111 & $0.26364 \mid$ & 0.26364 & $10.000 \mid$ & $8.17464 \mid$ & 20.000001 & | Averaged | \\
\hline 116 & 6 Acetone & । & 50.000001 & 49.513101 & 0.03920 & 10.0001 & 0.973801 & 20.000001 & | wt Linear| \\
\hline 17 & 7 trans-1,2-Dichloroethene & । & 0.343951 & 0.333711 & 0.33371 & $10.000 \mid$ & 2.976221 & 20.000001 & | Averaged | \\
\hline 18 & 8 Methyl Acetate & । & 50.000001 & 49.733091 & 0.01711 & $10.000 \mid$ & 0.533821 & 20.000001 & | wit Linear| \\
\hline 19 & 9 n-Hexane & । & $0.07787 \mid$ & 0.080221 & 0.08022 & 10.0001 & -3.02175 & 20.000001 & | Averaged | \\
\hline 120 & 0 MTBE & । & 0.448911 & 0.420781 & 0.42078 & 10.0001 & $6.26644 \mid$ & 20.000001 & | Averaged | \\
\hline 121 & 1 Acetonitrile & । & 2501 & 2311 & 0.01090 & 10.0001 & $7.45128 \mid$ & 60.000001 & | wit Linear| \\
\hline 122 & 2 2-Chloro-1,3-butadiene & । & $0.59207 \mid$ & $0.57007 \mid$ & 0.57007 & $10.000 \mid$ & $3.71569 \mid$ & 20.000001 & | Averaged | \\
\hline 123 & 31,1 -Dichloroethane & । & 0.669611 & 0.627411 & 0.62741 & $|0.100|$ & 6.301511 & 20.000001 & | Averaged | \\
\hline 124 & 4 Acrylonitrile & । & 0.041311 & 0.041381 & 0.04138 & 10.0001 & $-0.17849 \mid$ & 20.000001 & | Averaged | \\
\hline 125 & 5 vinyl acetate & । & 0.210121 & 0.187591 & 0.18759 & $10.000 \mid$ & $10.72584 \mid$ & 20.000001 & | Averaged | \\
\hline $\mid \mathrm{M}$ & 26 1,2-Dichloroethene (total) & । & $0.32517 \mid$ & 0.316411 & 0.31641 & 10.0001 & 2.692501 & 20.000001 & | Averaged | \\
\hline 127 & 7 cis-1,2-Dichloroethene & । & 0.306381 & 0.299111 & 0.29911 & $10.000 \mid$ & 2.374001 & 20.000001 & | Averaged | \\
\hline 128 & 8 2,2-Dichloropropane & । & 0.468391 & 0.446401 & 0.44640 & 10.0001 & $4.69557 \mid$ & 20.000001 & | Averaged | \\
\hline 130 & o Bromochloromethane & । & $0.09297 \mid$ & 0.089661 & 0.08966 & 10.0001 & 3.567381 & 20.000001 & | Averaged | \\
\hline 129 & 9 Cyclohexane & । & 0.554241 & 0.546451 & 0.54645 & 10.0001 & 1.40506 & 20.000001 & | Averaged | \\
\hline | 31 & 1 Chloroform & । & 0.488961 & 0.463501 & 0.46350 & 10.0001 & $5.20717 \mid$ & 20.000001 & | Averaged | \\
\hline 133 & 3 Ethyl acetate & 1 & 0.013671 & 0.012611 & 0.01261 & 10.0001 & 7.743331 & 20.000001 & | Averaged | \\
\hline 132 & 2 Carbon Tetrachloride & । & 0.426011 & 0.412521 & 0.41252 & 10.0001 & 3.165741 & 20.000001 & | Averaged | \\
\hline 134 & 4 Tetrahydrofuran & । & 0.010701 & 0.010431 & 0.01043 & $10.000 \mid$ & $2.51466 \mid$ & 20.000001 & | Averaged | \\
\hline & 35 Dibromofluorome thane & । & $0.19906 \mid$ & 0.193191 & 0.19319 & 10.0001 & 2.945111 & 20.000001 & | Averaged | \\
\hline 136 & $61,1,1$-Trichloroethane & । & 0.489751 & 0.478221 & 0.47822 & 10.0001 & 2.353201 & 20.000001 & | Averaged | \\
\hline 137 & 72 -Butanone & । & $0.03807 \mid$ & 0.037481 & 0.03748 & 10.0001 & 1.539001 & 20.000001 & | Averaged | \\
\hline 139 & 9 1,1-Dichloropropene & 1 & 0.463951 & 0.441911 & 0.44191 & 10.0001 & 4.749761 & 20.000001 & | Averaged | \\
\hline 140 & 0 Benzene & । & 1.225061 & 1.170221 & 1.17022 & 10.0001 & 4.47693 & 20.000001 & | Averaged | \\
\hline 41 & 1 Propionitrile & । & $0.01448 \mid$ & 0.013231 & 0.01323 & $10.000 \mid$ & 8.670261 & 20.000001 & | Averaged | \\
\hline 142 & 2 Methacrylonitrile & 1 & 0.059711 & 0.053321 & 0.05332 & $10.000 \mid$ & 10.716131 & 20.000001 & | Averaged | \\
\hline & 431,2 -Dichloroethane-d4 & । & 0.208081 & 0.189681 & 0.18968 & 10.0001 & 8.841911 & 20.000001 & | Averaged | \\
\hline 144 & 4 1,2-Dichloroethane & 1 & 0.258791 & 0.236961 & 0.23696 & $10.000 \mid$ & 8.433981 & 20.000001 & | Averaged | \\
\hline
\end{tabular}


Data Eile: FICV5585.D

Report Date: 16-Jun-2011 17:50

TestAmerica St. Louis

CONTINUING CALIBRATION COMPOUNDS

Instrument ID: MSE.i

Lab File ID: FICV5585. D

Injection Date: 12-JUN-2011 21:07

Analysis Type: WATER

Init. Cal. Date(s): 12-JUN-2011 12-JUN-2011

Lab Sample ID: ICV050

Init. Cal. Times: 17:27 20:18

Quant Type: ISTD

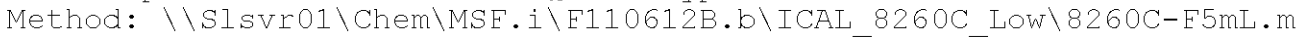

\begin{tabular}{|c|c|c|c|c|c|c|c|c|c|}
\hline | & & 1 & । & 1 & CCAL & $|\operatorname{MIN}|$ & । & MAX & । \\
\hline 10 & COMPOUND & IRRF & / AMOUNT | & RF50 & RRF50 & | RRF $\mid \frac{\circ}{0}$ & $\mathrm{D} / \mathrm{g} \mathrm{DRIFT} \mid \stackrel{\circ}{\mathrm{D}}$ & / $\frac{\circ}{D} \mathrm{DRIFT} \mid$ & | CURVE TYPE | \\
\hline 45 & Isobutanol & । & 0.004301 & $0.00367 \mid$ & 0.00367 & $10.000 \mid$ & $14.72458 \mid$ & 20.000001 & | Averaged | \\
\hline 47 & Methylcyclohexane & । & $0.50293 \mid$ & 0.474311 & 0.47431 & $10.000 \mid$ & 5.690631 & 20.000001 & | Averaged | \\
\hline 48 & Trichloroethene & I & 0.306241 & 0.292241 & 0.29224 & $|0.000|$ & 4.570071 & 20.000001 & | Averaged | \\
\hline 49 & n-Butanol & । & 5001 & 4471 & 0.00233 & $10.000 \mid$ & $10.61599 \mid$ & 20.000001 & | wt Linear| \\
\hline 150 & Dibromomethane & । & $0.08969 \mid$ & 0.084991 & 0.08499 & 10.0001 & $5.24028 \mid$ & 20.000001 & | Averaged | \\
\hline | 51 & 1,2-Dichloropropane & । & 0.279011 & $0.26794 \mid$ & 0.26794 & $10.000 \mid$ & 3.966611 & 20.000001 & | Averaged | \\
\hline 152 & Bromodichloromethane & । & 0.265251 & 0.255891 & 0.25589 & 10.0001 & 3.526101 & 20.000001 & | Averaged | \\
\hline 153 & Methyl methacrylate & 1 & $0.07116 \mid$ & $0.06827 \mid$ & 0.06827 & $10.000 \mid$ & 4.055211 & 20.000001 & | Averaged | \\
\hline 154 & 1,4-Dioxane & । & 0.00095 । & 0.000911 & 0.000911 & 10.0001 & 3.834281 & 20.000001 & | Averaged | \\
\hline 155 & 2-Chloroethylvinyl ether & । & $0.03817 \mid$ & 0.040851 & 0.04085 & 10.0001 & $-7.03432 \mid$ & 20.000001 & | Averaged | \\
\hline 156 & cis-1,3-Dichloropropene & । & $0.31434 \mid$ & 0.326191 & 0.32619 & $10.000 \mid$ & $-3.77133 \mid$ & 20.000001 & | Averaged | \\
\hline |\$ & 57 Toluene-d8 & । & 1.434661 & $1.46164 \mid$ & 1.46164 & 10.0001 & $-1.88047 \mid$ & 20.000001 & | Averaged | \\
\hline 158 & Toluene & । & 1.15575 & 1.067431 & 1.06743 & 10.0001 & 7.642391 & 20.000001 & | Averaged | \\
\hline 159 & 2-Nitropropane & । & 50.000001 & $43.07677 \mid$ & 0.06053 & $10.000 \mid$ & $13.84647 \mid$ & 60.000001 & | wt Linear| \\
\hline 162 & 4-Methyl-2-pentanone & । & $0.14616 \mid$ & $0.12339 \mid$ & 0.12339 & $10.000 \mid$ & 15.579501 & 20.000001 & | Averaged | \\
\hline 160 & Tetrachloroethene & । & 0.302631 & $0.29668 \mid$ & 0.29668 & 10.0001 & 1.96596 & 20.000001 & | Averaged | \\
\hline 163 & trans-1,3-Dichloropropene & । & 0.365511 & 0.352151 & 0.35215 & $10.000 \mid$ & 3.655161 & 20.000001 & | Averaged | \\
\hline 164 & $1,1,2$-Trichloroethane & । & $0.16904 \mid$ & $0.15658 \mid$ & 0.15658 & $10.000 \mid$ & $7.37209 \mid$ & 20.000001 & | Averaged | \\
\hline 165 & Ethyl methacrylate & । & $0.25653 \mid$ & 0.244351 & 0.24435 & 10.0001 & $4.74667 \mid$ & 20.000001 & | Averaged | \\
\hline 166 & Chlorodibromomethane & । & 0.215331 & 0.204761 & 0.20476 & 10.0001 & 4.91135 & 20.000001 & | Averaged | \\
\hline 167 & 1,3-Dichloropropane & । & $0.37718 \mid$ & 0.365731 & 0.36573 & 10.0001 & 3.035001 & 20.000001 & | Averaged | \\
\hline 168 & 1,2-Dibromoethane & । & 0.16465 & $0.16797 \mid$ & 0.16797 & $10.000 \mid$ & $-2.01416 \mid$ & 20.000001 & | Averaged | \\
\hline 169 & 2-Hexanone & । & 0.095261 & $0.08119 \mid$ & 0.08119 & $|0.000|$ & 14.773851 & 20.000001 & | Averaged | \\
\hline 171 & Chlorobenzene & । & $1.06484 \mid$ & $1.06879 \mid$ & 1.06879 & $10.300 \mid$ & -0.370821 & 20.000001 & | Averaged | \\
\hline 172 & Ethylbenzene & 1 & $2.31297 \mid$ & $2.14574 \mid$ & 2.14574 & 10.0001 & 7.229761 & 20.000001 & | Averaged | \\
\hline 173 & $1,1,1,2$-Tetrachloroethane & 1 & $0.33799 \mid$ & 0.314621 & 0.31462 & 10.0001 & 6.914921 & 20.000001 & | Averaged | \\
\hline 174 & $\mathrm{~m}, \mathrm{p}$-Xylenes & 1 & 0.799001 & 0.790901 & 0.79090 & 10.0001 & 1.01295 & 20.000001 & | Averaged | \\
\hline 175 & o-XYlene & । & 0.747861 & 0.747531 & 0.747531 & 10.0001 & 0.044281 & 20.000001 & | Averaged | \\
\hline 176 & styrene & 1 & 0.999521 & $1.04364 \mid$ & 1.04364 & $10.000 \mid$ & $-4.41493 \mid$ & 20.000001 & | Averaged | \\
\hline 177 & Bromoform & । & 0.208531 & 0.212401 & 0.21240 & $|0.100|$ & $-1.85119 \mid$ & 20.000001 & | Averaged | \\
\hline 178 & Isopropylbenzene & I & $4.47438 \mid$ & 4.463431 & 4.46343 & 10.0001 & 0.244781 & 20.000001 & | Averaged | \\
\hline $\mid \xi$ & 794 -Bromofluorobenzene & 1 & 1.108531 & 1.143551 & 1.14355 & 10.0001 & $-3.15895 \mid$ & 20.000001 & | Averaged | \\
\hline 180 & Bromobenzene & । & $0.74093 \mid$ & 0.748631 & 0.74863 & 10.0001 & $-1.03895 \mid$ & 20.000001 & | Averaged | \\
\hline 181 & n-Fropylbenzene & । & 6.301481 & 5.957101 & 5.95710 & $|0.000|$ & 5.465011 & 20.000001 & | Averaged | \\
\hline 182 & $1,1,2,2$-Tetrachloroethane & । & $0.56784 \mid$ & 0.507071 & 0.50707 & $|0.300|$ & 10.702501 & 20.000001 & | Averaged | \\
\hline 183 & 2-Chlorotoluene & । & 3.880461 & 3.948651 & 3.94865 & $10.000 \mid$ & $-1.75737 \mid$ & 20.000001 & | Averaged | \\
\hline 184 & 1,3,5-Trimethylbenzene & 1 & 4.41065 & 4.270111 & 4.27011 & 10.0001 & 3.186401 & 20.000001 & | Averaged | \\
\hline 185 & 1,2,3-Trichloropropane & 1 & 50.000001 & 58.227821 & 0.53798 & $10.000 \mid$ & $-16.45564 \mid$ & 20.000001 & Linearl \\
\hline 186 & trans-1,4-dichloro-2-butene & 1 & 0.194431 & 0.170091 & 0.17009 & $10.000 \mid$ & $12.51704 \mid$ & 20.000001 & | Averaged | \\
\hline 187 & Cyclohexanone & I & 5001 & 4401 & 0.01571 & 10.0001 & $12.03139 \mid$ & 20.000001 & | wt Linear | \\
\hline 188 & 4-Chlorotoluene & 1 & 3.246901 & 3.262941 & 3.26294 & 10.0001 & -0.494131 & 20.000001 & | Averaged | \\
\hline 189 & t-Butylbenzene & 1 & 3.547751 & 3.594981 & 3.594981 & 10.0001 & -1.331321 & 20.000001 & | Averaged | \\
\hline 191 & $1,2,4$-Trimethylbenzene & 1 & 4.204451 & 4.019231 & 4.01923 & $10.000 \mid$ & 4.405491 & 20.000001 & | Averaged | \\
\hline
\end{tabular}


Data Eile: FICV5585.D

Report Date: 16-Jun-2011 17:50

TestAmerica st. Louis

CONTINUING CALIBRATION COMPOUNDS

Instrument ID: MSE.i

Lab File ID: FICV5585.D

Injection Date: 12-JUN-2011 21:07

Analysis Type: WATER

Init. Cal. Date(s): 12-JUN-2011 12-JUN-2011

Lab Sample ID: ICV050

Init. Cal. Times: 17:27 20:18

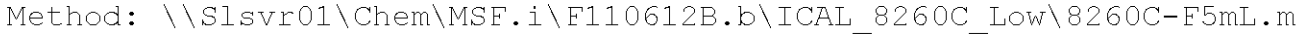

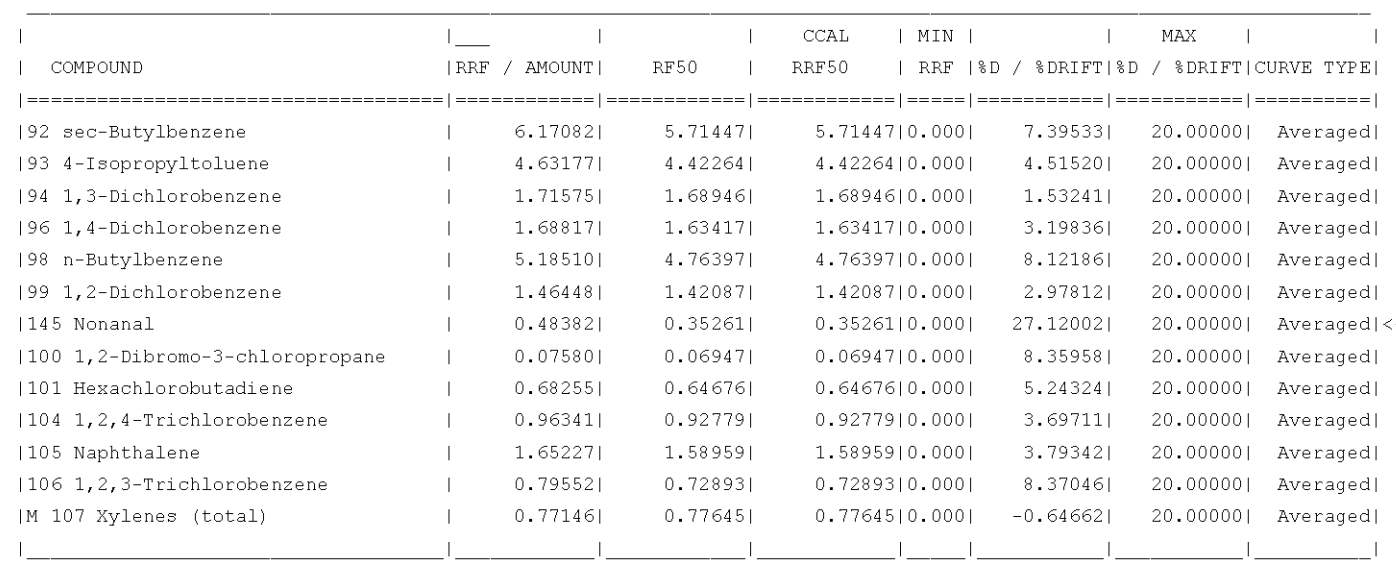




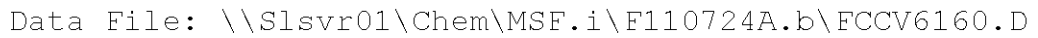

Report Date: 25-Jul-2011 14:24

TestAmerica st. Louis

CONTINUING CALIBRATION COMPOUNDS

Instrument ID: MSE.i

Lab File ID: FCCV6160.D

Injection Date: 24-JUL-2011 13:01

Analysis Type: WATER

Init. Cal. Date(s): 12-JUN-2011 12-JUN-2011

Lab Sample ID: VSTD010

Init. Cal. Times: 17:27

$20: 18$

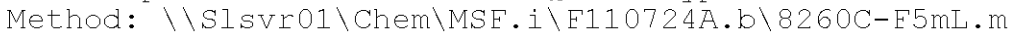

\begin{tabular}{|c|c|c|c|c|c|c|c|c|c|}
\hline । & & & । & । & CCAL & MIN I & । & MAX & 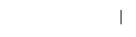 \\
\hline 1 & COMPOUND & | RRF & / AMOUNT | & RF50 & RRF50 & | RRF |딤 & $\mathrm{D} / \mathrm{\circ} \mathrm{DRIFT} \mid \stackrel{\circ}{\mathrm{D}}$ & \multicolumn{2}{|c|}{ / 음FT|CURVE TYPE| } \\
\hline $\mid==-$ & 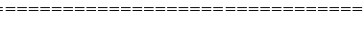 & $=1=$ & $========\mid$ & $=======\mid=$ & - & $\mid=====$ & $=======\mid$ & $=======$ & $========1$ \\
\hline$|1|$ & Dichlorodif luorome thane & । & $0.45388 \mid$ & $0.45029 \mid$ & 0.45029 & $|0.000|$ & $0.78998 \mid$ & 20.000001 & Averaged | \\
\hline 12 & Freon-114 & । & 0.185601 & 0.173221 & 0.17322 & $10.000 \mid$ & $6.66957 \mid$ & 20.000001 & Averaged I \\
\hline 130 & Chloromethane & । & 0.583831 & 0.610601 & 0.61060 & $|0.100|$ & $-4.58397 \mid$ & 20.000001 & Averagedl \\
\hline $\mid 4$ & Vinyl Chloride & । & 0.572751 & $0.56129 \mid$ & 0.56129 & $|0.000|$ & 2.000801 & 20.000001 & Averaged। \\
\hline 151 & Bromomethane & । & 0.159201 & $0.14367 \mid$ & $0.14367 \mid$ & $10.000 \mid$ & 9.754651 & 20.000001 & Averaged I \\
\hline 160 & Chloroethane & । & 0.237861 & $0.22564 \mid$ & 0.22564 & $|0.000|$ & 5.139251 & 20.000001 & Averaged | \\
\hline 17 & Trichlorofluoromethane & 1 & $0.52928 \mid$ & 0.515201 & 0.51520 & 10.0001 & 2.659521 & 20.000001 & Averaged I \\
\hline 181 & Diethyl ether & । & $0.08348 \mid$ & 0.085061 & $0.08506 \mid$ & $10.000 \mid$ & $-1.89316 \mid$ & 20.000001 & Averaged I \\
\hline 19 & 1,1-Dichloroethene & 1 & $0.31166 \mid$ & 0.307941 & 0.30794 & $10.000 \mid$ & $1.19448 \mid$ & 20.000001 & Averaged। \\
\hline 110 & Carbon Disulfide & 1 & 1.143761 & 1.121901 & 1.12190 & 10.0001 & $1.91137 \mid$ & 20.000001 & Averaged I \\
\hline | 11 & 1,1,2-Trichlorofluoroethane & । & 0.20459 & $0.19484 \mid$ & 0.19484 & $10.000 \mid$ & 4.763311 & 20.000001 & Averaged। \\
\hline | 12 & 2 Iodomethane & । & 0.387251 & 0.378421 & 0.378421 & 10.0001 & $2.28127 \mid$ & 20.000001 & Averaged। \\
\hline | 13 & Acrolein & । & 0.011801 & 0.015891 & 0.01589 & 10.0001 & -34.633411 & 20.000001 & Averaged 1 \\
\hline | 14 & Allyl chloride & । & 0.350791 & 0.334451 & 0.33445 & $10.000 \mid$ & 4.658651 & 20.000001 & Averaged I \\
\hline 115 & Methylene Chloride & । & 0.287111 & 0.267831 & 0.26783 & $10.000 \mid$ & 6.717901 & 20.000001 & Averaged I \\
\hline 116 & 5 Acetone & । & 50.000001 & 53.060191 & 0.04175 & $10.000 \mid$ & $-6.12038 \mid$ & 20.000001 & wt Linearl \\
\hline | 17 & trans-1,2-Dichloroethene & । & $0.34395 \mid$ & 0.338381 & 0.33838 & $10.000 \mid$ & $1.61856 \mid$ & 20.000001 & Averaged I \\
\hline | 18 & Methyl Acetate & । & 50.000001 & 53.539721 & 0.018421 & 10.0001 & -7.079431 & 20.000001 & wt Linearl \\
\hline 19 & $\mathrm{n}$-Hexane & । & $0.07787 \mid$ & 0.076631 & 0.07663 & $10.000 \mid$ & 1.59166 & 20.000001 & Averaged। \\
\hline 120 & MTBE & । & 0.448911 & 0.457261 & 0.45726 & 10.0001 & $-1.86015 \mid$ & 20.000001 & Averaged I \\
\hline 121 & Acetonitrile & । & 2501 & 2721 & 0.01279 & $10.000 \mid$ & $-8.62225 \mid$ & 60.000001 & wit Linearl \\
\hline $\mid 22$ & 2-Chloro-1,3-butadiene & 1 & $0.59207 \mid$ & $0.60285 \mid$ & 0.60285 & 10.0001 & $-1.82095 \mid$ & 20.000001 & Averaged I \\
\hline 123 & 1,1 -Dichloroethane & । & 0.669611 & $0.62028 \mid$ & 0.62028 & $|0.100|$ & $7.36696 \mid$ & 20.000001 & Averaged I \\
\hline 124 & Acrylonitrile & । & 0.041311 & 0.039431 & 0.039431 & 10.0001 & 4.548441 & 20.000001 & Averagedl \\
\hline 125 & Vinyl acetate & । & 0.210121 & 0.225151 & 0.22515 & 10.0001 & $-7.15117 \mid$ & 20.000001 & Averaged। \\
\hline | M & 26 1,2-Dichloroethene (total) & । & $0.32517 \mid$ & $0.31364 \mid$ & 0.31364 & 10.0001 & 3.545201 & 20.000001 & Averaged I \\
\hline 127 & cis-1,2-Dichloroethene & । & $0.30638 \mid$ & 0.288901 & 0.28890 & 10.0001 & $5.70807 \mid$ & 20.000001 & Averaged I \\
\hline 128 & 2,2-Dichloropropane & । & 0.46839 & 0.449861 & 0.44986 & 10.0001 & $3.95707 \mid$ & 20.000001 & Averaged I \\
\hline | 30 & Bromochloromethane & 1 & $0.09297 \mid$ & 0.091531 & 0.091531 & $10.000 \mid$ & $1.54867 \mid$ & 20.000001 & Averaged। \\
\hline 129 & Cyclohexane & । & $0.55424 \mid$ & 0.537901 & $0.53790 \mid$ & $|0.000|$ & 2.948181 & 20.000001 & Averaged I \\
\hline | 31 & Chloroform & 1 & $0.48896 \mid$ & $0.44384 \mid$ & $0.44384 \mid$ & 10.0001 & 9.226621 & 20.000001 & Averaged I \\
\hline 133 & Ethyl acetate & 1 & 0.013671 & 0.013181 & 0.013181 & 10.0001 & 3.627041 & 20.000001 & Averaged I \\
\hline 132 & Carbon Tetrachloride & 1 & 0.426011 & 0.375231 & 0.375231 & $10.000 \mid$ & 11.92055 & 20.000001 & Averaged। \\
\hline | 34 & Tetrahydrofuran & । & 0.010701 & 0.012281 & $0.01228 \mid$ & $10.000 \mid$ & -14.81686 & 20.000001 & Averaged। \\
\hline |\$ & 35 Dibromofluorome thane & । & 0.199061 & 0.202031 & 0.20203 & $10.000 \mid$ & $-1.49551 \mid$ & 20.000001 & Averaged I \\
\hline 136 & $51,1,1$-Trichloroethane & । & 0.489751 & 0.454621 & 0.45462 & $10.000 \mid$ & $7.17278 \mid$ & 20.000001 & Averaged I \\
\hline | 37 & 2-Butanone & । & 0.038071 & $0.03754 \mid$ & 0.03754 & 10.0001 & $1.38314 \mid$ & 20.000001 & Averaged। \\
\hline | 39 & 1,1-Dichloropropene & 1 & 0.463951 & 0.436181 & 0.43618 & $10.000 \mid$ & 5.986151 & 20.000001 & Averaged I \\
\hline 140 & Benzene & । & 1.22506 & $1.11733 \mid$ & 1.11733 & $10.000 \mid$ & 8.794531 & 20.000001 & Averaged I \\
\hline | 41 & Propionitrile & । & $0.01448 \mid$ & $0.01529 \mid$ & 0.01529 & 10.0001 & -5.603501 & 20.000001 & Averaged। \\
\hline $\mid 42$ & Methacrylonitrile & 1 & 0.059711 & 0.061241 & 0.06124 & 10.0001 & $-2.55969 \mid$ & 20.000001 & Averaged I \\
\hline |\$ & 43 1,2-Dichloroethane-d4 & 1 & 0.208081 & 0.21129 & 0.21129 & 10.0001 & -1.541801 & 20.000001 & Averagedl \\
\hline | 44 & $1,2-$ - ichloroethane & 1 & 0.258791 & 0.249101 & 0.24910 & 10.0001 & 3.744451 & 20.000001 & Averaged। \\
\hline
\end{tabular}




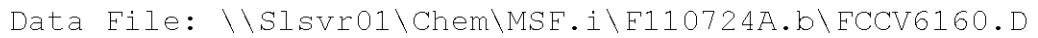

Report Date: 25-Jul-2011 14:24

TestAmerica st. Louis

CONTINUING CALIBRATION COMPOUNDS

Instrument ID: MSE.i

Lab File ID: FCCV6160.D

Injection Date: 24-JUL-2011 13:01

Analysis Type: WATER

Init. Cal. Date(s): 12-JUN-2011 12-JUN-2011

Lab Sample ID: VSTD010

Init. Cal. Times: 17:27

$20: 18$

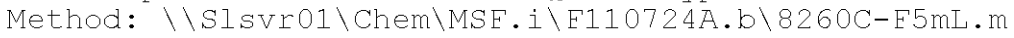

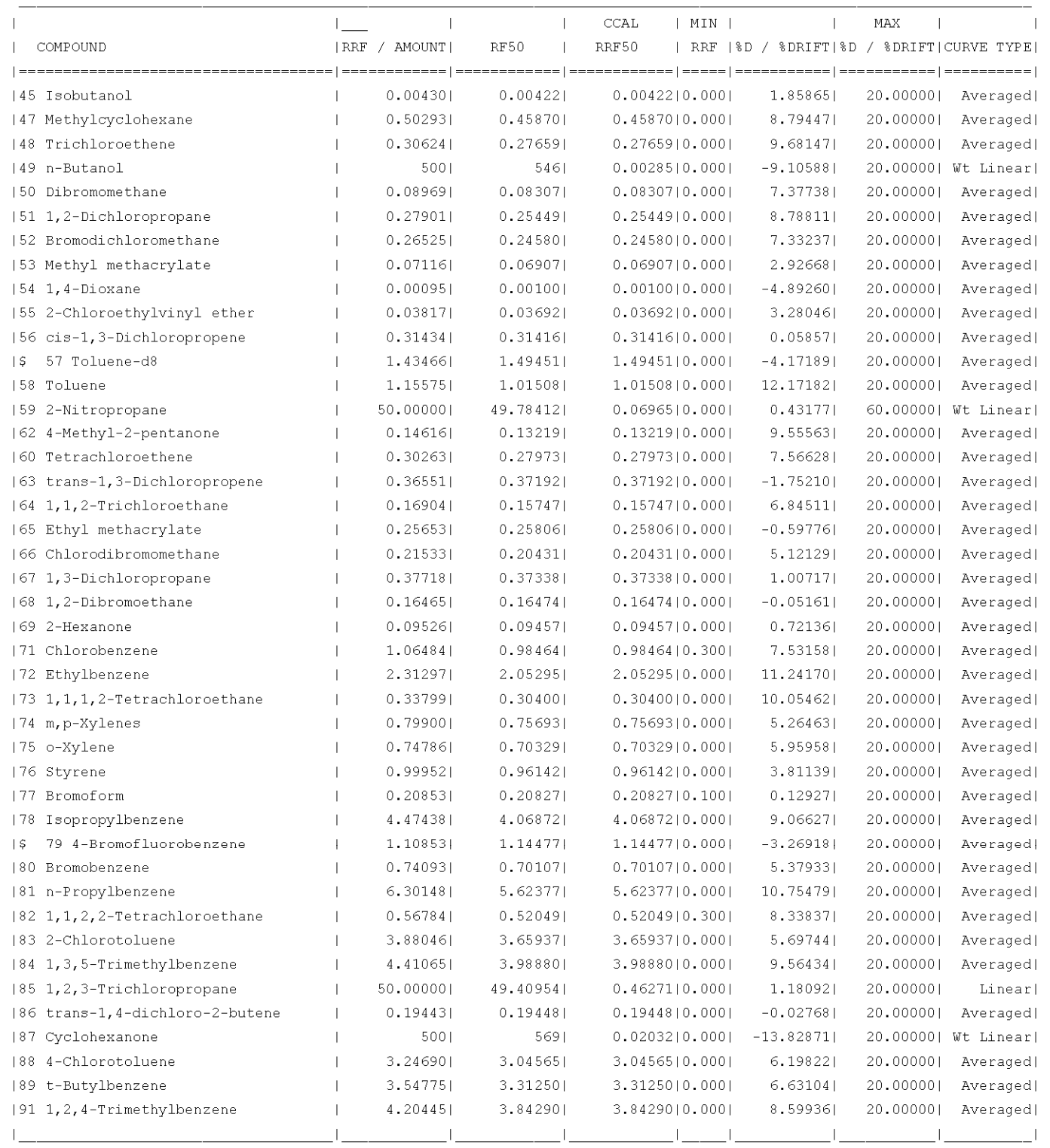




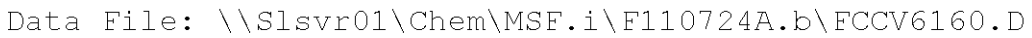

Report Date: 25-Jul-2011 14:24

$$
\text { TestAmerica St. Louis }
$$

CONTINUING CALIBRATION COMPOUNDS

Instrument ID: MSE.i

Lab File ID: FCCV6160.D

Analysis Type: WATER

Lab Sample ID: VSTD010

Injection Date: 24-JUL-2011 13:01

Init. Cal. Date(s): 12-JUN-2011 12-JUN-2011

Init. Cal. Times: 17:27 20:18

Quant Type: ISTD

Method: \\Slsvr01 \Chem\MSF.i \F110724A.b\8260C-F5mL.m

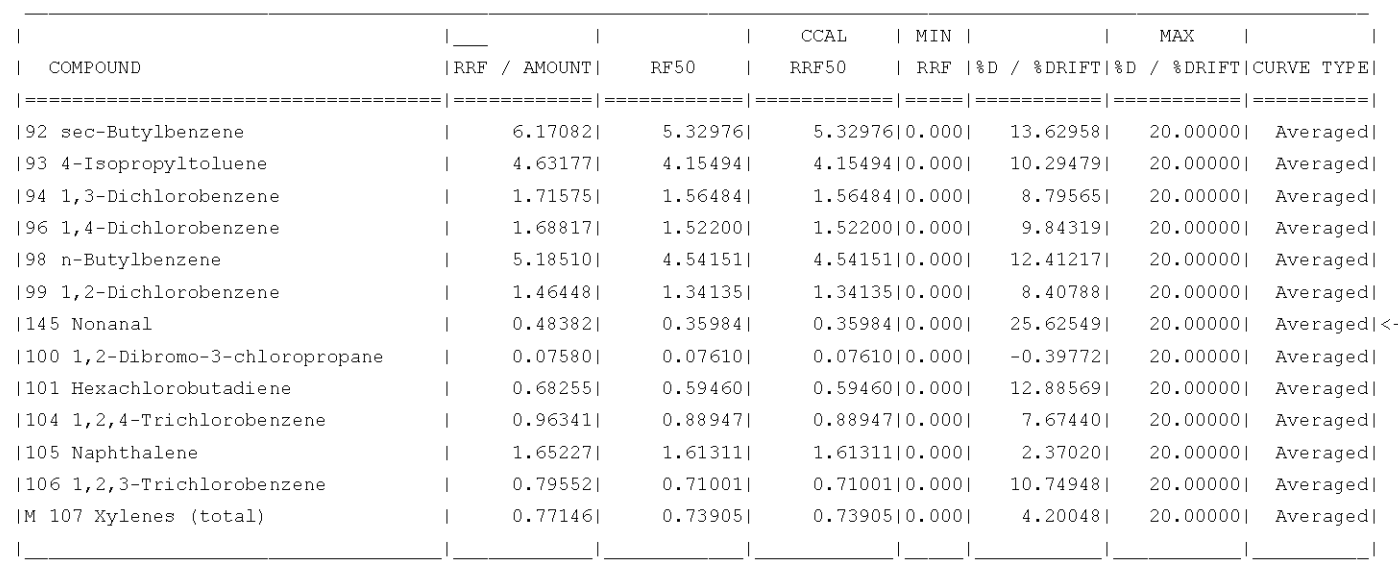


FORM 8

VOLATILE INTERNAL STANDARD AREA AND RT SUMMARY

Lab Name: TESTAMERICA ST. LOUIS

Lab Code:

Case No. :

Lab File ID (Standard): ECCV6160

Instrument ID: MSE

GC Column: RTX-VMS ID: 0.25 (mm)
Contract: 9661

SAS NO.:

SDG No.: F1G200464

Date Analyzed: 07/24/11

Time Analyzed: 1301

Heated Purge: (Y/N) Y

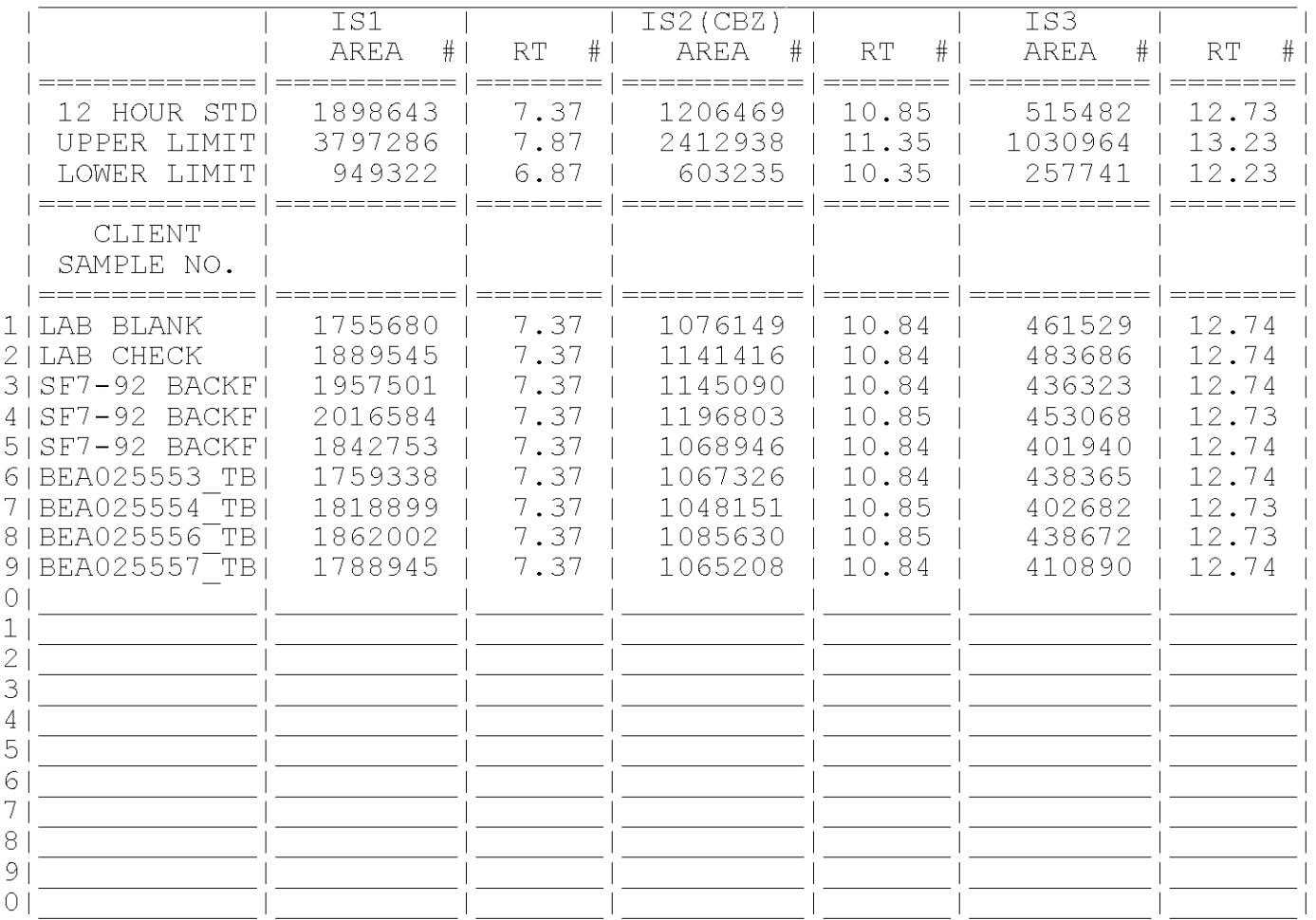

IS1 = Fluorobenzene

IS2 (CBZ) = Chlorobenzene-d5

IS3 $=1,4$ Dichlorobenzene-d4

AREA UPPER LIMIT $=+100 \%$ of internal standard area AREA LOWER LIMIT $=-50 \%$ of internal standard area

RT UPPER LIMIT $=+0.50$ minutes of internal standard RT

RT LOWER LIMIT $=-0.50$ minutes of internal standard RT

\# Column used to flag values outside QC limits with an asterisk.

* Values outside of QC limits.

page 1 of 1

EORM VIII VOA 
BEA-SOW-8500, REV.4

GC/MS MISCELLANEOUS DATA 
Assigned Surrogates/Internal Standards *

\begin{tabular}{|c|c|c|}
\hline Compound & Assigned Surrogate & $\begin{array}{c}\text { Assigned Internal } \\
\text { Standard }\end{array}$ \\
\hline Dichlorodifluoromethane & Dibromofluoromethane & Fluorobenzene \\
\hline Freon-114 & Dibromofluoromethane & Fluorobenzene \\
\hline Chloromethane & Dibromofluoromethane & Fluorobenzene \\
\hline Vinyl Chloride & Dibromofluoromethane & Fluorobenzene \\
\hline Bromomethane & Dibromofluoromethane & Fluorobenzene \\
\hline Chloroethane & Dibromofluoromethane & Fluorobenzene \\
\hline Trichlorofluoromethane & Dibromofluoromethane & Fluorobenzene \\
\hline Diethyl Ether & Dibromofluoromethane & Fluorobenzene \\
\hline 1,1-Dichloroethene & Dibromofluoromethane & Fluorobenzene \\
\hline 1,1,2-Trichlorofluoroethane & Dibromofluoromethane & Fluorobenzene \\
\hline Carbon Disulfide & Dibromofluoromethane & Fluorobenzene \\
\hline lodomethane & Dibromofluoromethane & Fluorobenzene \\
\hline Acrolein & Dibromofluoromethane & Fluorobenzene \\
\hline Allyl chloride & Dibromofluoromethane & Fluorobenzene \\
\hline Methylene Chloride & Dibromofluoromethane & Fluorobenzene \\
\hline Acetone & Dibromofluoromethane & Fluorobenzene \\
\hline Methyl Acetate & Dibromofluoromethane & Fluorobenzene \\
\hline trans-1,2-Dichloroethene & Dibromofluoromethane & Fluorobenzene \\
\hline n-Hexane & Dibromofluoromethane & Fluorobenzene \\
\hline Acetonitrile & Dibromofluoromethane & Fluorobenzene \\
\hline MTBE & Dibromofluoromethane & Fluorobenzene \\
\hline 2-Chloro-1,3-butadiene & Dibromofluoromethane & Fluorobenzene \\
\hline 1,1-Dichloroethane & Dibromofluoromethane & Fluorobenzene \\
\hline 1,2-Dichloroethene (total) & Dibromofluoromethane & Fluorobenzene \\
\hline Acrylonitrile & Dibromofluoromethane & Fluorobenzene \\
\hline Vinyl acetate & Dibromofluoromethane & Fluorobenzene \\
\hline cis-1,2-Dichloroethene & Dibromofluoromethane & Fluorobenzene \\
\hline 2,2-Dichloropropane & Dibromofluoromethane & Fluorobenzene \\
\hline Bromochloromethane & Dibromofluoromethane & Fluorobenzene \\
\hline 2-Butoxyethanol & Dibromofluoromethane & Fluorobenzene \\
\hline Cyclohexane & Dibromofluoromethane & Fluorobenzene \\
\hline Chloroform & Dibromofluoromethane & Fluorobenzene \\
\hline t-Butyl Alcohol & Dibromofluoromethane & Fluorobenzene \\
\hline Diisopropyl Ether & Dibromofluoromethane & Fluorobenzene \\
\hline ETBE & Dibromofluoromethane & Fluorobenzene \\
\hline Ethanol & Dibromofluoromethane & Fluorobenzene \\
\hline 2,2-Dimethylpentane & Dibromofluoromethane & Fluorobenzene \\
\hline 2,4-Dimethylpentane & Dibromofluoromethane & Fluorobenzene \\
\hline 2,2,3-Trimethylbutane & Dibromofluoromethane & Fluorobenzene \\
\hline
\end{tabular}




\begin{tabular}{|c|c|c|}
\hline 3,3-Dimethylpentane & Dibromofluoromethane & Fluorobenzene \\
\hline Ethyl Acetate & Dibromofluoromethane & Fluorobenzene \\
\hline Carbon Tetrachloride & Dibromofluoromethane & Fluorobenzene \\
\hline Tetrahydrofuran & Dibromofluoromethane & Fluorobenzene \\
\hline 1,1,1-Trichloroethane & 1,2-Dichloroethane-d4 & Fluorobenzene \\
\hline 2-Butanone & 1,2-Dichloroethane-d4 & Fluorobenzene \\
\hline 1,1-Dichloropropene & 1,2-Dichloroethane-d4 & Fluorobenzene \\
\hline Heptane & 1,2-Dichloroethane-d4 & Fluorobenzene \\
\hline Benzene & 1,2-Dichloroethane-d4 & Fluorobenzene \\
\hline Propionitrile & 1,2-Dichloroethane-d4 & Fluorobenzene \\
\hline Methacrylonitrile & 1,2-Dichloroethane-d4 & Fluorobenzene \\
\hline |sobutanol & 1,2-Dichloroethane-d4 & Fluorobenzene \\
\hline 1,2-Dichloroethane & 1,2-Dichloroethane-d4 & Fluorobenzene \\
\hline Trichloroethene & 1,2-Dichloroethane-d4 & Fluorobenzene \\
\hline Methyl cyclohexane & 1,2-Dichloroethane-d4 & Fluorobenzene \\
\hline n-butanol & 1,2-Dichloroethane-d4 & Fluorobenzene \\
\hline Dibromomethane & 1,2-Dichloroethane-d4 & Fluorobenzene \\
\hline 1,2-Dichloropropane & 1,2-Dichloroethane-d4 & Fluorobenzene \\
\hline Bromodichloromethane & 1,2-Dichloroethane-d4 & Fluorobenzene \\
\hline Methyl methacrylate & 1,2-Dichloroethane-d4 & Fluorobenzene \\
\hline 1,4-Dioxane & 1,2-Dichloroethane-d4 & Fluorobenzene \\
\hline Cis-1,3-Dichloropropene & 1,2-Dichloroethane-d4 & Fluorobenzene \\
\hline 2-Chloroethylvinyl ether & 1,2-Dichloroethane-d4 & Fluorobenzene \\
\hline TAME & 1,2-Dichloroethane-d4 & Fluorobenzene \\
\hline 2-Methylhexane & 1,2-Dichloroethane-d4 & Fluorobenzene \\
\hline 2,3-Dimethylpentane & 1,2-Dichloroethane-d4 & Fluorobenzene \\
\hline 3-Methylhexane & 1,2-Dichloroethane-d4 & Fluorobenzene \\
\hline 3-Ethypentane & 1,2-Dichloroethane-d4 & Fluorobenzene \\
\hline Heptane & 1,2-Dichloroethane-d4 & Fluorobenzene \\
\hline Toluene & Toluene-d8 & Chlorobenzene-d5 \\
\hline Dimethyl Disulfide & Toluene-d8 & Chlorobenzene-d5 \\
\hline 2-Nitropropane & Toluene-d8 & Chlorobenzene-d5 \\
\hline 4-Methyl-2-pentanone (MEK) & Toluene-d8 & Chlorobenzene-d5 \\
\hline trans-1,3-Dichloropropene & Toluene-d8 & Chlorobenzene-d5 \\
\hline Tetrachloroethene & Toluene-d8 & Chlorobenzene-d5 \\
\hline Ethyl methacrylate & Toluene-d8 & Chlorobenzene-d5 \\
\hline 1,1,2-Trichloroethane & Toluene-d8 & Chlorobenzene-d5 \\
\hline Chlorodibromomethane & Toluene-d8 & Chlorobenzene-d5 \\
\hline 1,3-Dichloropropane & Toluene-d8 & Chlorobenzene-d5 \\
\hline 1,2-Dibromoethane & Toluene-d8 & Chlorobenzene-d5 \\
\hline 2-Hexanone & Toluene-d8 & Chlorobenzene-d5 \\
\hline Ethylbenzene & Toluene-d8 & Chlorobenzene-d5 \\
\hline Chlorobenzene & Toluene-d8 & Chlorobenzene-d5 \\
\hline
\end{tabular}




\begin{tabular}{|c|c|c|}
\hline 1,1,1,2-Tetrachloroethane & Toluene-d8 & Chlorobenzene-d5 \\
\hline m,p-Xylenes & Toluene-d8 & Chlorobenzene-d5 \\
\hline o-Xylenes & Toluene-d8 & Chlorobenzene-d5 \\
\hline Styrene & Toluene-d8 & Chlorobenzene-d5 \\
\hline 1-Chlorohexane & Toluene-d8 & Chlorobenzene-d5 \\
\hline Bromoform & Toluene-d8 & 1,4-Dichlorobenzene-d4 \\
\hline Isopropylbenzene & Toluene-d8 & 1,4-Dichlorobenzene-d4 \\
\hline n-Propylbenzene & 4-Bromofluorobenzene & 1,4-Dichlorobenzene-d4 \\
\hline 1,1,2,2-Tetrachloroethane & 4-Bromofluorobenzene & 1,4-Dichlorobenzene-d4 \\
\hline Bromobenzene & 4-Bromofluorobenzene & 1,4-Dichlorobenzene-d4 \\
\hline 1,3,5-Trimethylbenzene & 4-Bromofluorobenzene & 1,4-Dichlorobenzene-d4 \\
\hline 2-Chlorotoluene & 4-Bromofluorobenzene & 1,4-Dichlorobenzene-d4 \\
\hline $\begin{array}{l}\text { trans-1,4-dichlorobenzene-2- } \\
\text { butene }\end{array}$ & 4-Bromofluorobenzene & 1,4-Dichlorobenzene-d4 \\
\hline 1,2,3-Trichloropropane & 4-Bromofluorobenzene & 1,4-Dichlorobenzene-d4 \\
\hline 4-Chlorotoluene & 4-Bromofluorobenzene & 1,4-Dichlorobenzene-d4 \\
\hline Cyclohexanone & 4-Bromofluorobenzene & 1,4-Dichlorobenzene-d4 \\
\hline t-Butylbenzene & 4-Bromofluorobenzene & 1,4-Dichlorobenzene-d4 \\
\hline 1,2,4-Trimethylbenzene & 4-Bromofluorobenzene & 1,4-Dichlorobenzene-d4 \\
\hline Pentachloroethane & 4-Bromofluorobenzene & 1,4-Dichlorobenzene-d4 \\
\hline sec-Butylbenzene & 4-Bromofluorobenzene & 1,4-Dichlorobenzene-d4 \\
\hline 4-Isopropyltoluene & 4-Bromofluorobenzene & 1,4-Dichlorobenzene-d4 \\
\hline 1,3-Dichlorobenzene & 4-Bromofluorobenzene & 1,4-Dichlorobenzene-d4 \\
\hline 1,4-Dichlorobenzene & 4-Bromofluorobenzene & 1,4-Dichlorobenzene-d4 \\
\hline n-Butylbenzene & 4-Bromofluorobenzene & 1,4-Dichlorobenzene-d4 \\
\hline 1,2-Dichlorobenzene & 4-Bromofluorobenzene & 1,4-Dichlorobenzene-d4 \\
\hline 1,3,5-trichlorobenzene & 4-Bromofluorobenzene & 1,4-Dichlorobenzene-d4 \\
\hline 1,2-Dibromo-3-chloropropane & 4-Bromofluorobenzene & 1,4-Dichlorobenzene-d4 \\
\hline Hexachlorobutadiene & 4-Bromofluorobenzene & 1,4-Dichlorobenzene-d4 \\
\hline 1,2,4-Trichlorobenzene & 4-Bromofluorobenzene & 1,4-Dichlorobenzene-d4 \\
\hline Naphthalene & 4-Bromofluorobenzene & 1,4-Dichlorobenzene-d4 \\
\hline 1,2,3-Trichlorobenzene & 4-Bromofluorobenzene & 1,4-Dichlorobenzene-d4 \\
\hline 4-Chlorophenyl methyl sulfide & 4-Bromofluorobenzene & 1,4-Dichlorobenzene-d4 \\
\hline
\end{tabular}

* ISTD assignment is based on instrument operating conditions and column type and may vary slightly from this listing. 


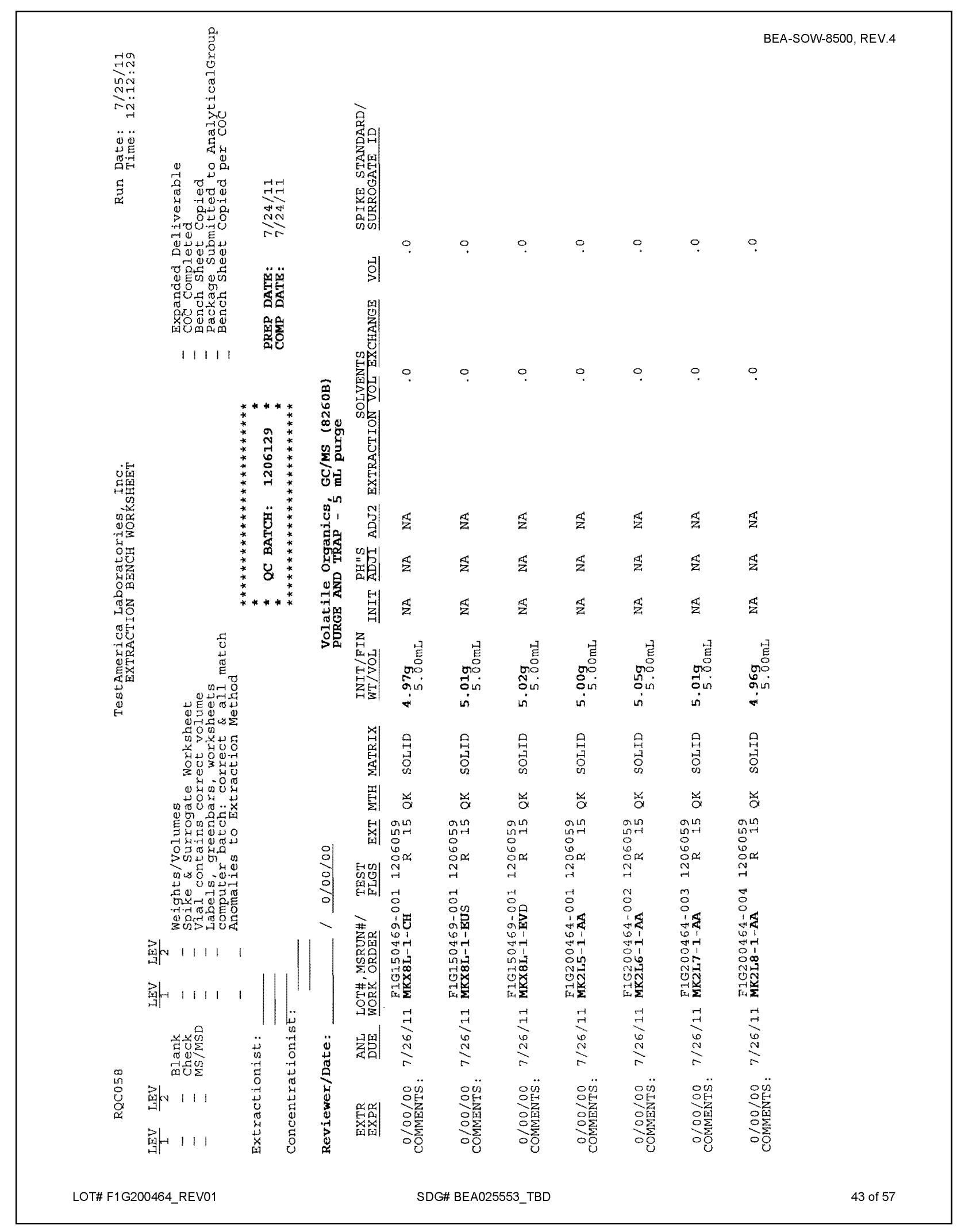




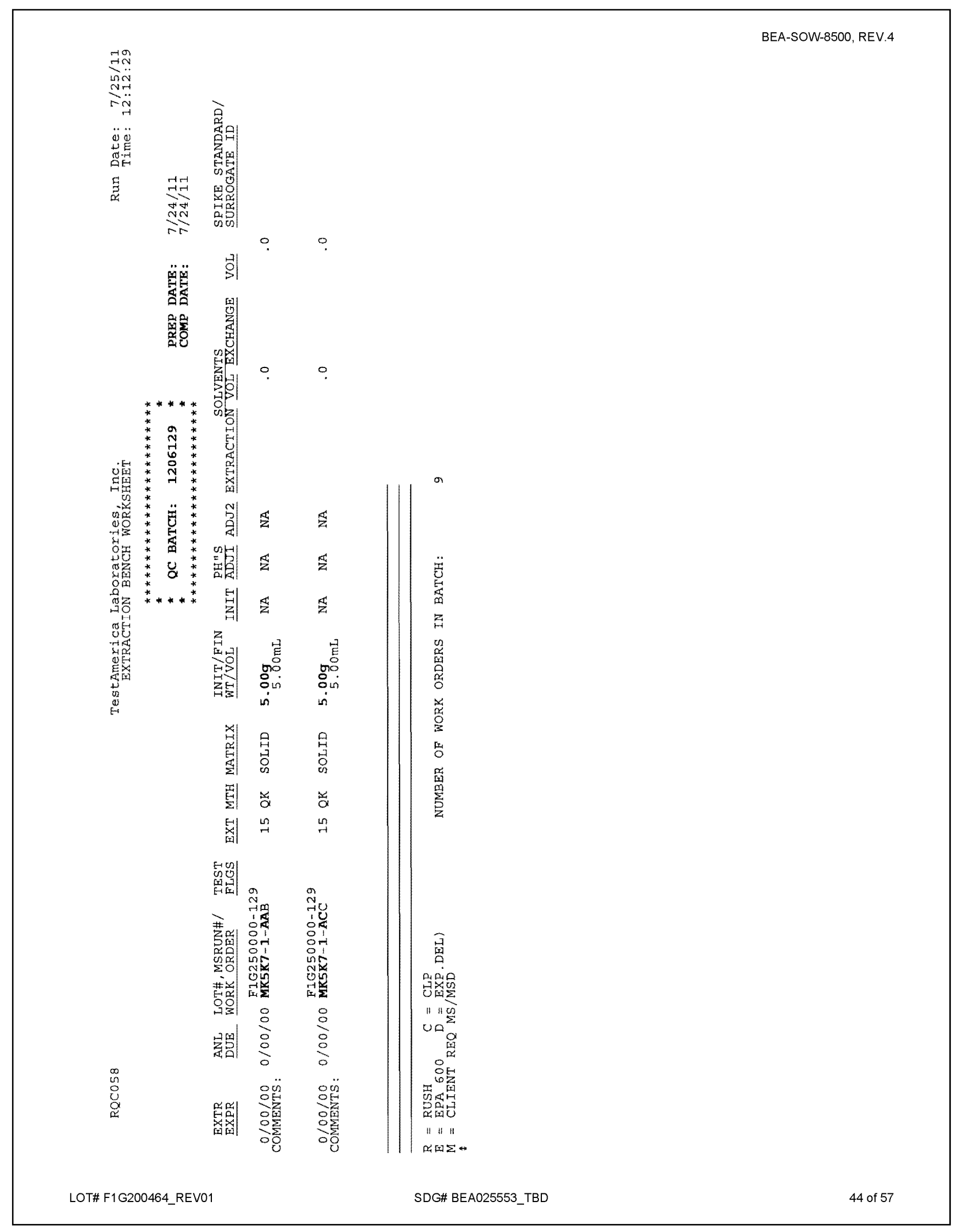




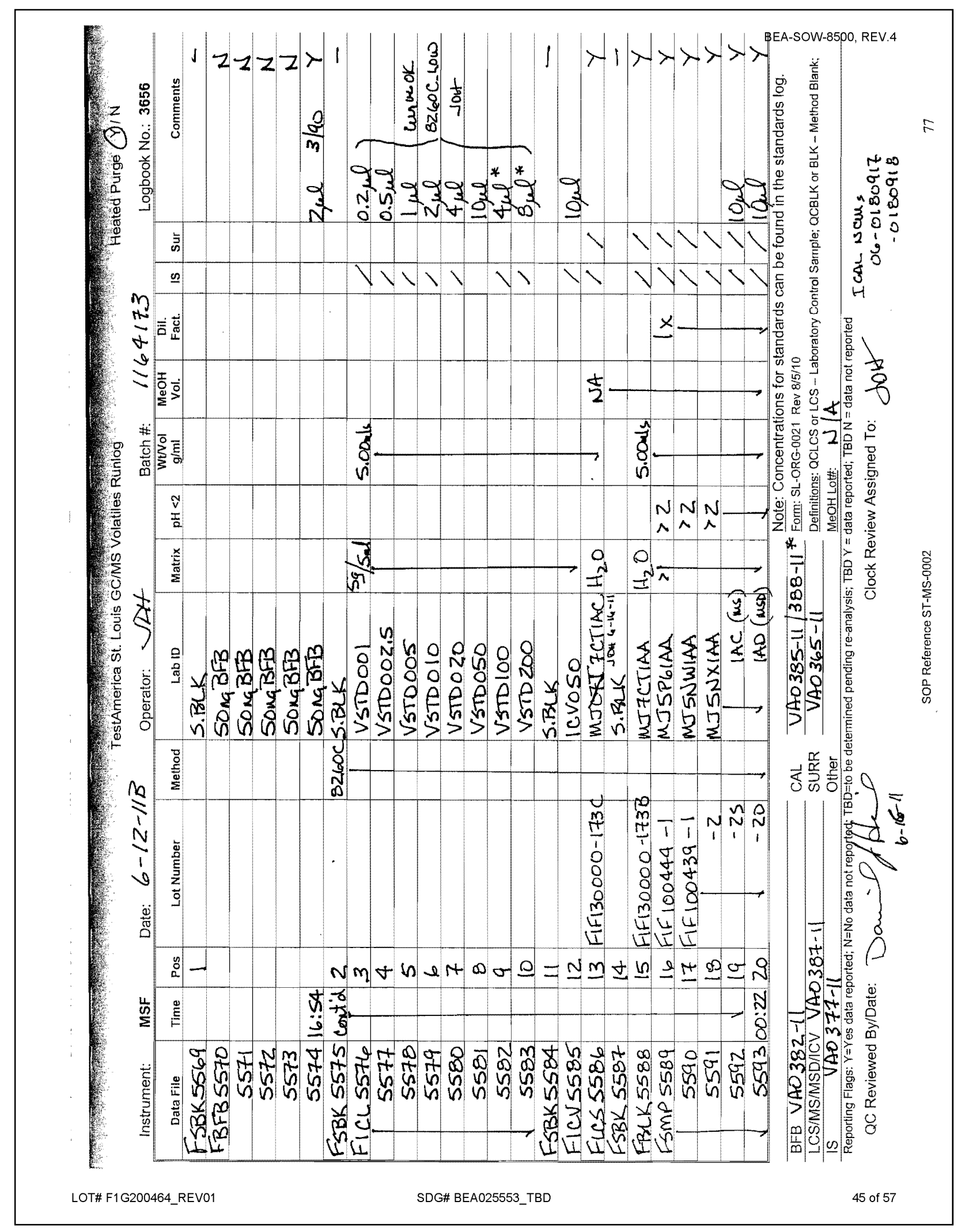




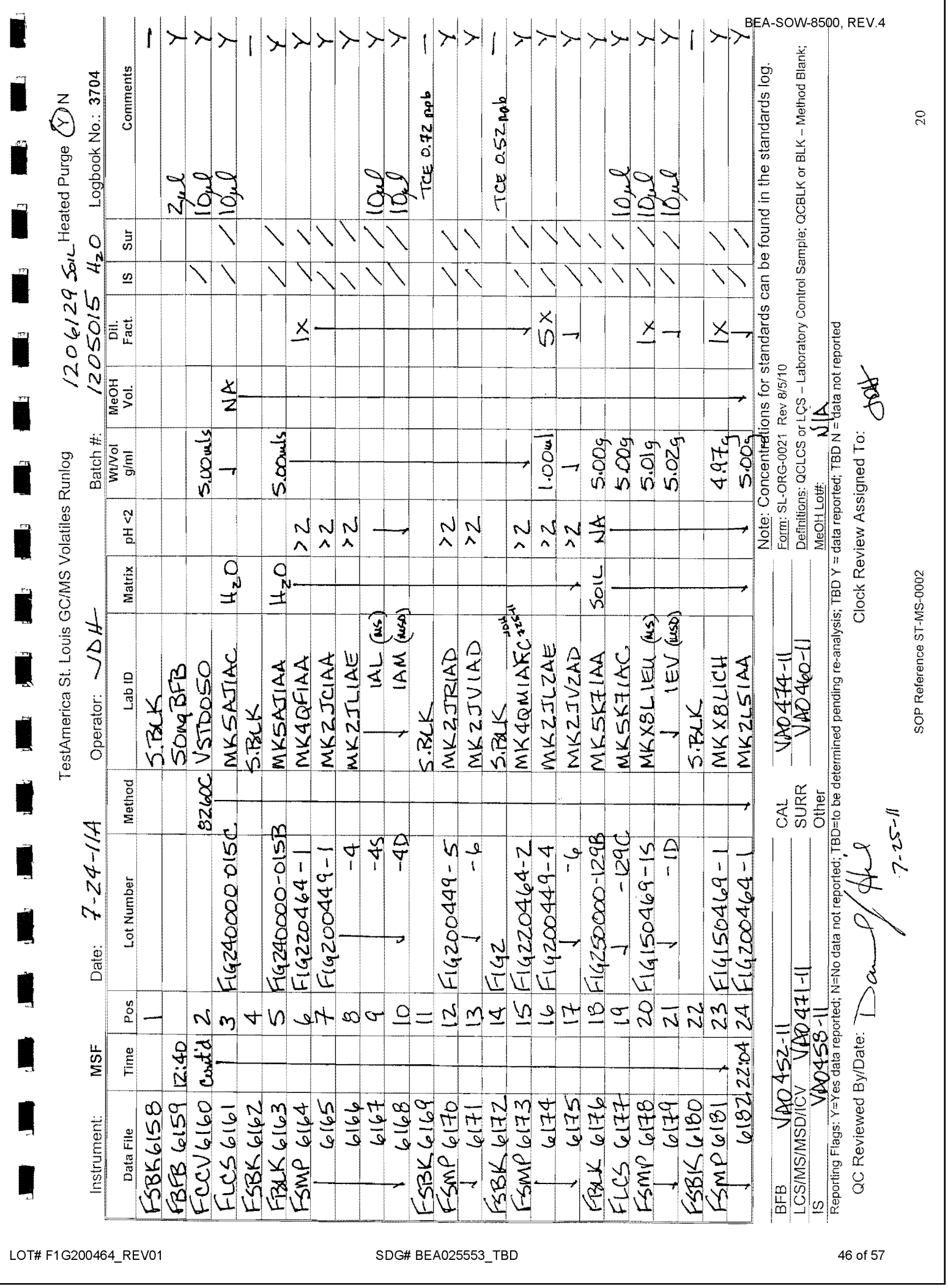




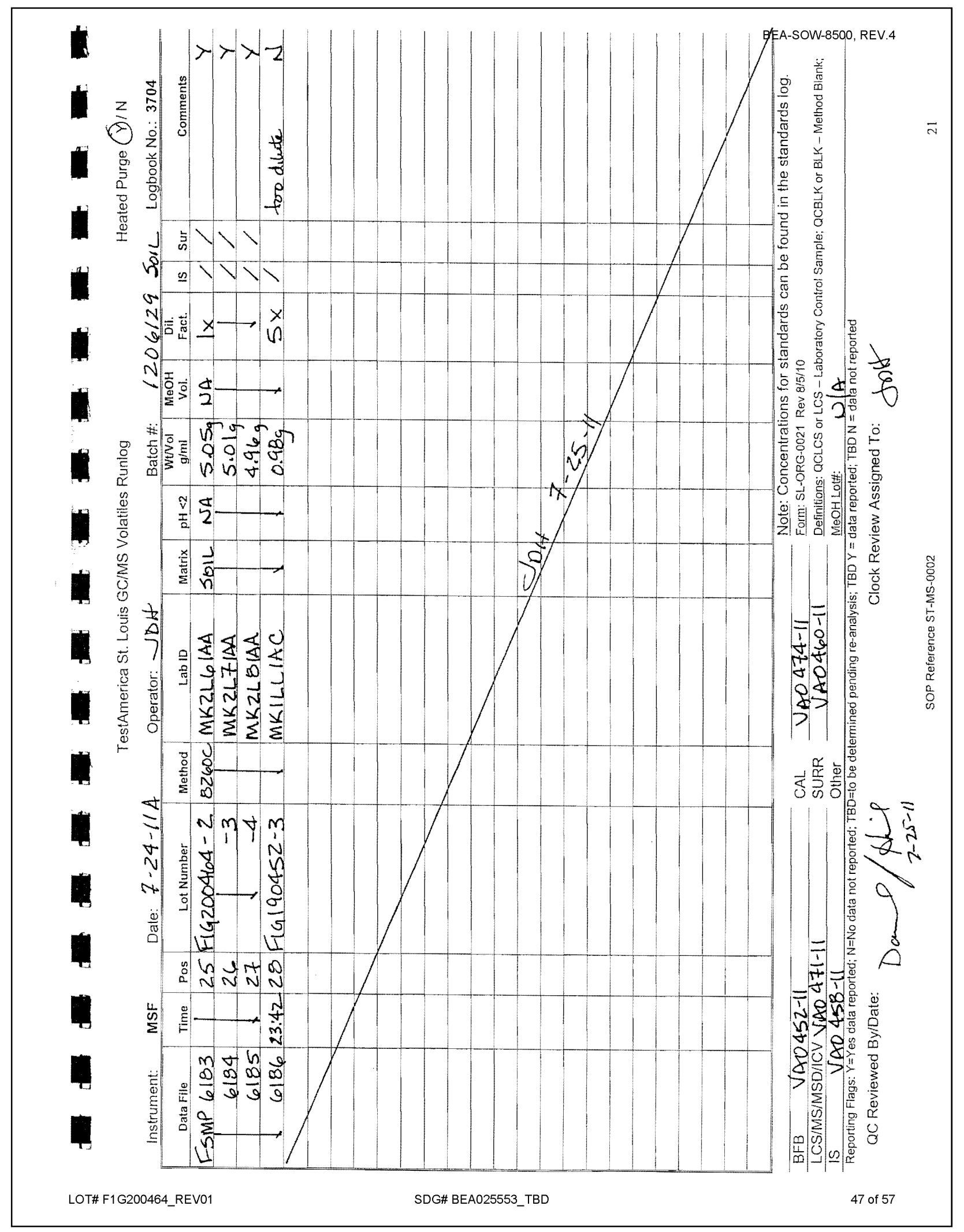




\section{TestAmerica}

TestAmerica St. Louis

Data Review Checklist GC/MS Volatiles

Clock ID: F110724A

12 Hour ISTD Reference: FCCV 6160

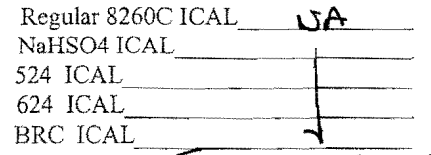

1) 1206129 solc

Special ICAL FllO6lZB 8260C_Low

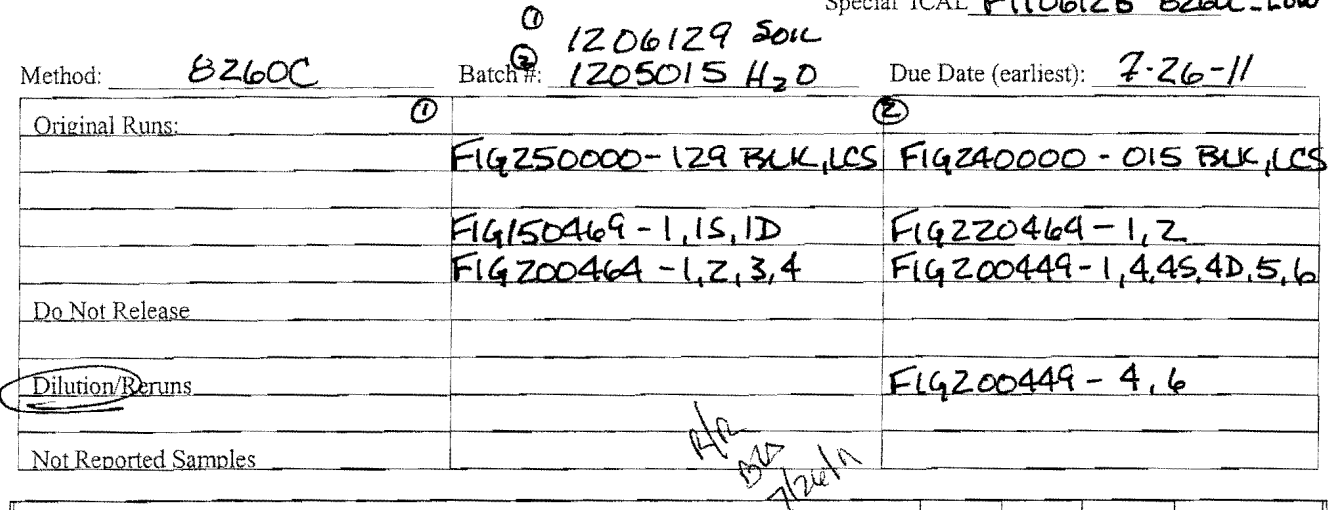

\begin{tabular}{|c|c|c|c|c|}
\hline Review Item & Yes & No & $\mathrm{N} / \mathrm{A}$ & $2^{\text {nd }}$ Review \\
\hline $\begin{array}{l}\text { A. Tuning } \\
\text { 1. BFB tuning meets method criteria? }\end{array}$ & & & & \\
\hline $\begin{array}{l}\text { B. Continuing Calibration (CCV) } \\
\text { 1. Continuing Calibration mects method acceptance criteria (max.20\%)? } \\
\text { If not, please reference NCM \# } 06-0183337\end{array}$ & & & & \\
\hline $\begin{array}{l}\text { C. Batch QC - Method Blanks } \\
\text { 1. Are the associated batch method blanks included in this submission? (No - only } \\
\text { applicable for medium level extractions and TCLP) } \\
\text { If not, please indicate where to find: }\end{array}$ & & & & \\
\hline $\begin{array}{l}\text { 2. Is the method blank "ND" for targets of interest? } \\
\text { If not, please reference NCM \# }\end{array}$ & & & & \\
\hline $\begin{array}{l}\text { D. Batch QC - LCS } \\
\text { 1. Are the associated batch LCSs included in this submission? (No -only applicable } \\
\text { for medium level extractions and TCLP) } \\
\text { If not, please indicate where to find: }\end{array}$ & & & & \\
\hline $\begin{array}{l}\text { 2. Are the LCS (LCSD) recoveries within method acceptance? } \\
\text { If not, please reference NCM \# } 06-0183338\end{array}$ & & & & \\
\hline $\begin{array}{l}\text { E. Batch QC-MS/MSD } \\
\text { 1. Are the associated bateh MS/MSDs included in this submission? (No -only } \\
\text { applicable for medium level extractions) } \\
\text { If not, please indicate where to find: }\end{array}$ & & & & \\
\hline $\begin{array}{l}\text { 2. MS/MSD performed? } \\
\text { If not, please reference NCM\# }\end{array}$ & & & & \\
\hline $\begin{array}{l}\text { 3. Are the MS/MSD recoveries within method acceptance? } \\
\text { If not, please reference NCM \# }\end{array}$ & & & & \\
\hline
\end{tabular}

Page 1 of 2

GCMS VOA Data Rewew QA/Foms/Review/GCMS VOA Revision 3 10/12/10 
TestAmerica

THE LEAERR HN ENUIRONHENTAL TESTING

TestAmerica St. Louis

Data Review Checklist

GC/MS Volatiles

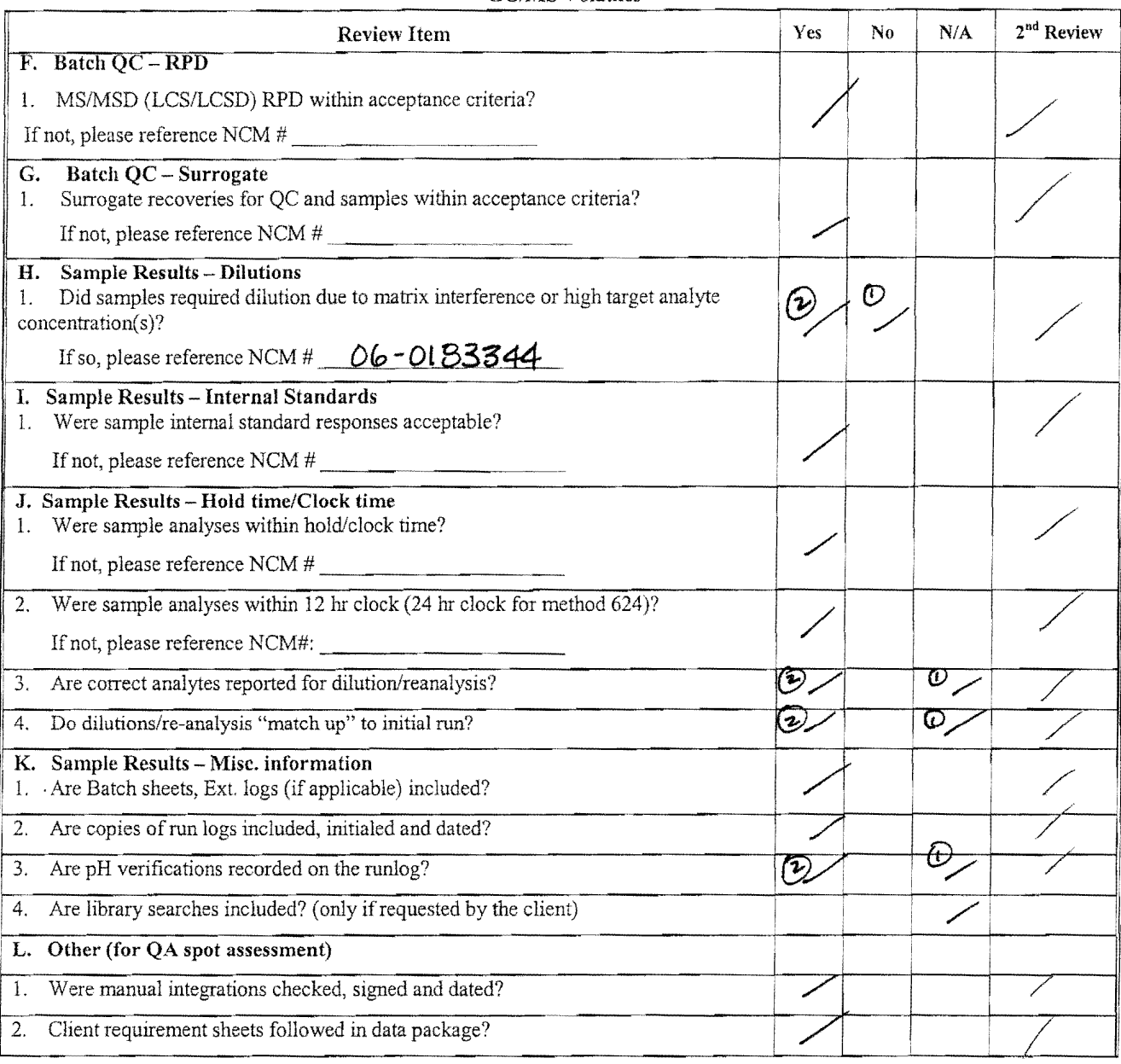

ICAL Naus 06-0180917,-0180918

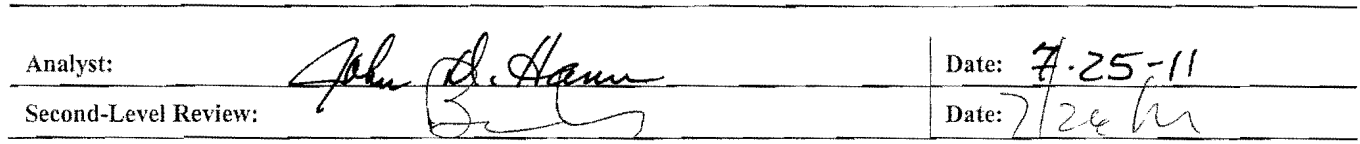

Page 2 of 2

GCMS VOA Data Review QAFOMmS/Review/OCMS YOA Revision 3 10/12/10 
BEA-SOW-8500, REV.4

Battelle Emergy $\mathbb{A} l i$ iance

CIiemt Sample $\mathbb{I D}: \mathrm{BE} \mathbb{R} 025553 \mathbb{M} \mathbb{R}$

General Chemistry

Lot-Sample \#...: F1G200464-001 Work Order \#...: MK2L5

Date Sampled...: 07/18/11 12:15 Date Received..: 07/20/11

웋 Moisture....: 15

FARAMETER

Percent Moistnre

RESULT

$\frac{R}{14.7}$ METHOD
$\mathrm{RI}$

0.10

Dilution Factor: 1
Matrix........ SOLID

PREPARATION- PREP ANAIYSIS DATE BATCH \# $\frac{07 / 22-07 / 23 / 11}{1203021}$

MCATWTW $160.3 \mathrm{MOD}$ 
BEA-SOW-8500, REV.4

Battelle Emergy $\mathbb{A} l i$ iance

CIiemt Sample $\mathbb{I D}: \mathrm{BE} \mathbb{R} 02555 \mathbb{4} \mathbb{R} \mathbb{B D}$

General Chemistry

Lot-Sample \#...: F1G200464-002 Work Order \#...: MK2L6

Date Sampled...: 07/18/11 14:15 Date Received..: 07/20/11

\% Moisture.....: 15

FARAMETER

Percent Moisture

RESULT

$\frac{\text { RESUL' }}{15 \cdot 4}$
Matrix........ SOLID

PREPARATION- PREP

$\frac{\text { ANALYSIS DATE }}{07 / 22-07 / 23 / 11} \frac{\text { BATCH \# }}{1203021}$ METHOD 
BEA-SOW-8500, REV.4

Battelle Emergy $\mathbb{A} l i$ iance

CIiemt Sample $\mathbb{I D}: \mathrm{BE} \mathbb{R} 025556 \mathbb{M} \mathbb{B D}$

General Chemistry

Lot-Sample \#...: F1G200464-003 Work Order \#...: MK2L7

Date Sampled...: 07/18/11 14:55 Date Received..: 07/20/11

웋 Moisture....: : 18

FARAMETER

Percent Moisture

RESULT

$\frac{R E S T}{17.6}$ METHOD
$\mathrm{RI}$

0.10

Dilution Factor:
Matrix........ SOLID

PREPARATION- PREP ANALYSIS DATE BATCH H $\frac{07 / 22-07 / 23 / 11}{1203021}$

MICATWTW $160.3 \mathrm{MOD}$ 
BEA-SOW-8500, REV.4

Battelle Emergy $\mathbb{A} l i$ iance

CIiemt Sample $\mathbb{I D}: \mathrm{BE} \mathbb{R} 025557$ "IIBD

General Chemistry

Lot-Sample \#...: F1G200464-004 Work Order \#...: MK2L8

Date Sampled...: 07/18/11 15:10 Date Received..: 07/20/11

\% Moisture.....: 14

FARAMETER

Percent Moisture

RESULT

13.9 METHOD
$\frac{\mathrm{RL}}{0.10}$

Dilution Factor: 1
Matrix........ SOLID

PREPARATION- PREP ANALYSIS DATE BATCH H
07/22-07/23/11 $\frac{\text { 1203021 }}{1201}$

MCA 160.3 MOD 
BEA-SOW-8500, REV.4

SAMPLE DUPLICATE EVALUATION REPORI

General Chemistry

Client Lot \#...: F1G200464

Work Order \#...: MK1D8-SMP

Thate Sampled...: 07/18/11 08:00

: Moisture....: 15

EARAM RESULT

Fercent Moisture

$15 \cdot 1$

DUPLICATE RESULT

17.0 $\underline{\text { RPD }}$ IIMIT METHOD MK1D8-DUP

Date Received..: 07/19/11

RPD

SD Lot-Sample \#:

Analysis Time... 00:00
(0-30) MCAWN $160.3 \mathrm{MOD} 07 / 22-07 / 23 / 111203021$

Matrix...... S SOLID

PREPARATTON- PREP ANALYSIS DATE BATCH \#

$07 / 22-07 / 23 / 11 \quad 1203021$ 


\section{F1G200464}

Project Manager: JK2

Project: $\quad 101847330$

PO\#:

Client:

9661

Battelle Energy Alliance

\section{CLIENT ANALYSIS SUMMARY}

Quote \#: 89239 SDG

TOS-A1147/TAN-664 Fuel Tank So

Report to: Peggy Sherbinske

RUSH

\#SMPS in LOT: 4

BEA-SOW-8500, REV.4

VS20

Date Received: $\quad 2011-07-20$

Analytical Due Date: $\quad$ 2011-07-26

Report Due Date: $\quad$ 2011-07-27

Report Type: $F \quad$ Forms Only EDD Code: 00

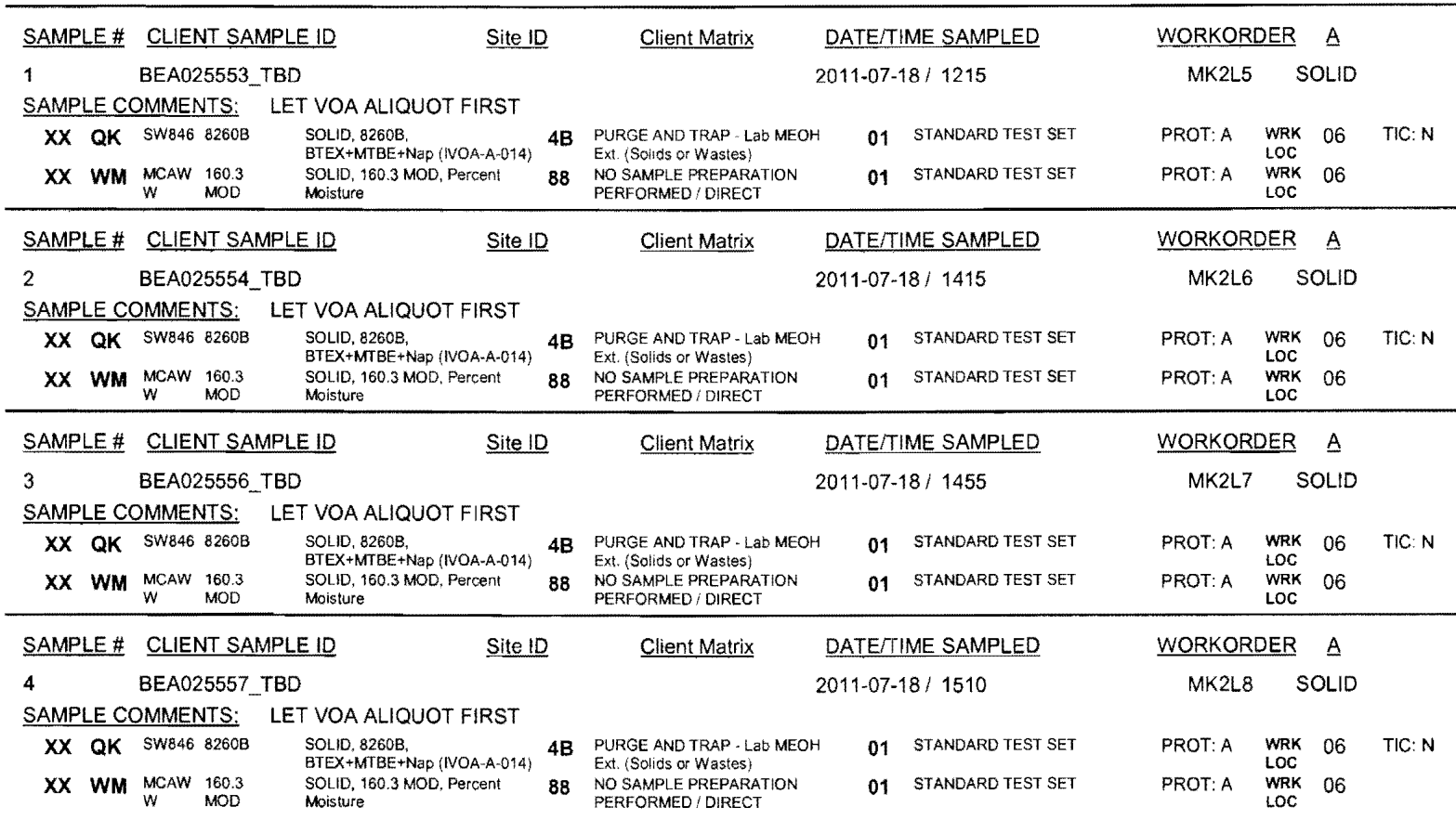

TestAmerica - St. Louis Logged in by: OWENSN 2011-07-20 13:45:19 Printed on: Wednesday, July 20, 2011 02:48 P 


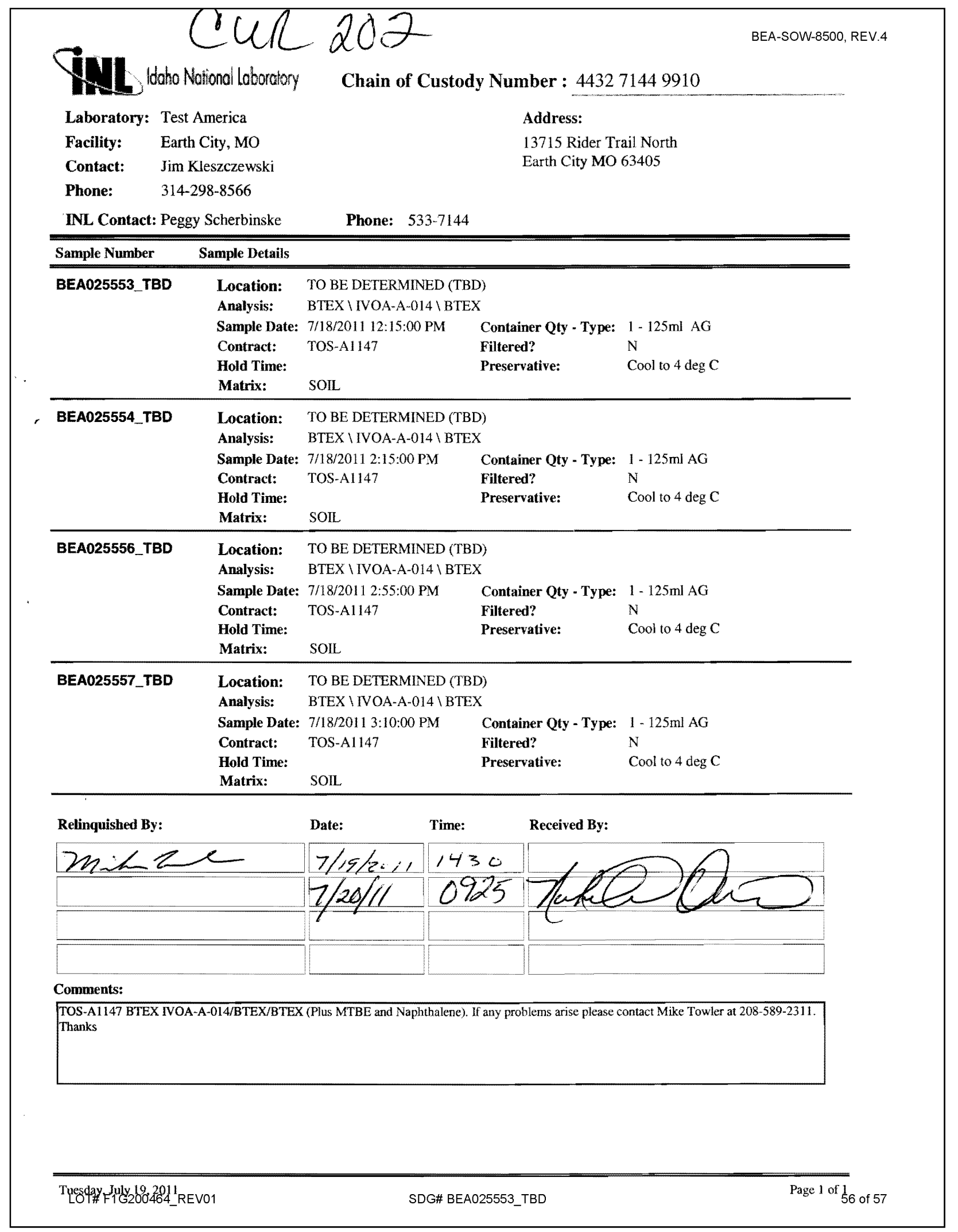




\section{TestAmerica \\ THE LEADER INENVIRONAENTAE TESTINS \\ CUR form \#: \\ CONDITION UPON RECEIPT FORM Client: IAXth NAT LAB \\ Quote No: \\ 89239 \\ COCRFA No: 443221449910 \\ Nod \\ Initiated By:}

Lot \#(s):

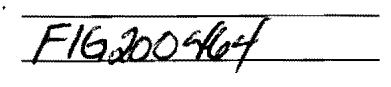

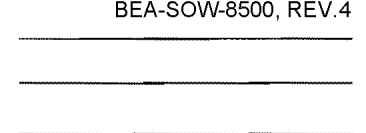

Shipper:

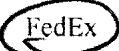

UPS

DHI Courier

\section{Shipping Information}

Shipping \# (s): *

Client Other:

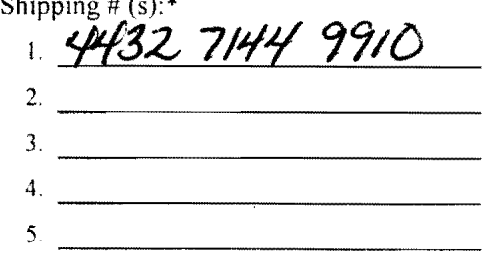

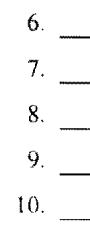

le remp lines

${ }^{* *}$ Sample must be received at $4{ }^{\circ} \mathrm{C} \pm$ 两 $\sim$ If not, note contents betow. Temperature variance does NOT affect the following: Metals-1,iquid: Rad tests- Lsquid or Solids: Perchlorate

Condition (Circle " $\mathrm{Y}$ " for yes, "N" for no and " $\mathrm{NA}$ " for not applicable):

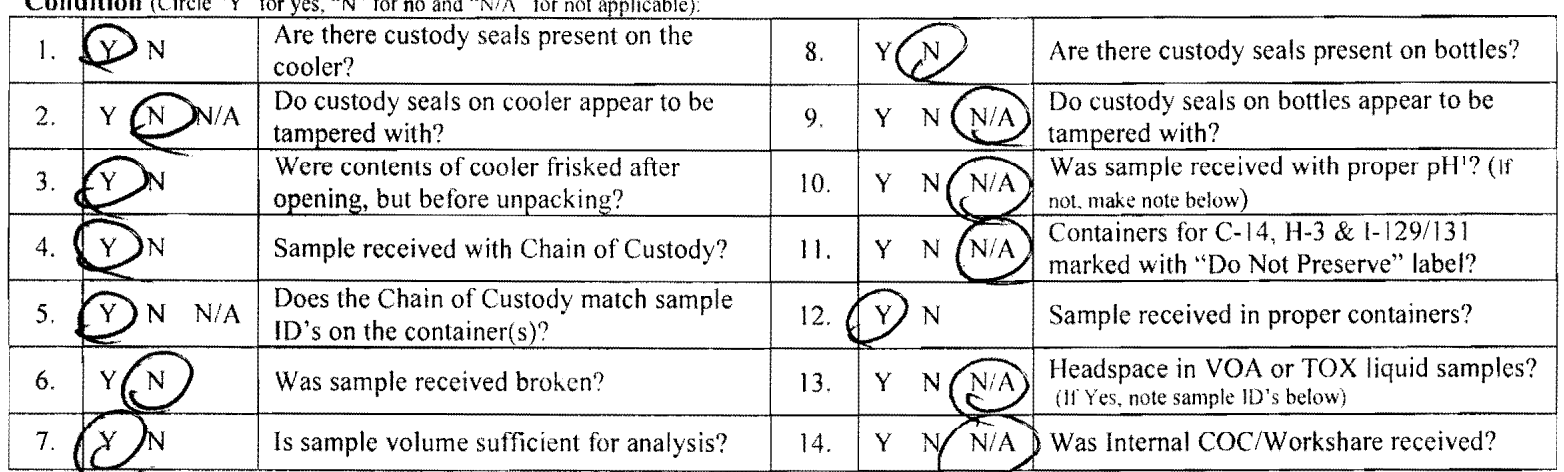

'For DOE-AL (Pantex, LANL, Sandia) sites, pH of ALI containers received must be verified EXCEPT WOA, TOX. Oil \& Grease and soils. Notes:

Corrective Action:

Client Contact Name:

Sample(s) processed "as is"

Sample(s) on hold until: Project Management Review:

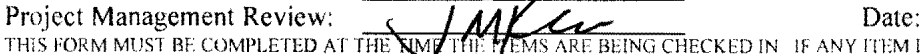

THAT PIRSON IS RE:QUIRED TO APPLY THEIR INITIAL AND THE DATE NEXT TO THATIIEM.

LOT\#F1G200464_REV01
Informed by:

If released, notify: Sample Temperature (s):**

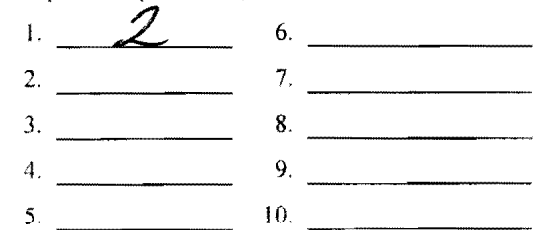
Time: 0925 Multiple Packages: $\quad \mathrm{N}$ 